\author{
University of Szeged \\ Faculty of Pharmacy \\ Department of Clinical Pharmacy
}

Ph.D. Thesis

\title{
GERIATRIC FALLS AND RISK FACTORS
}

\author{
Dr. Andrea Bor
}

Supervisors:

Prof. Dr. Gyöngyvér Soós

Dr. Péter Doró

Szeged

2017 


\section{TABLE OF CONTENTS}

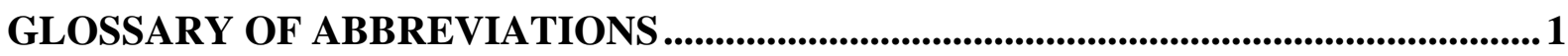

LIST OF PAPERS INCLUDED IN THE THESIS ............................................................ 3

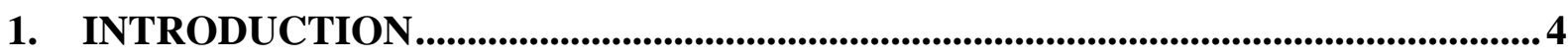

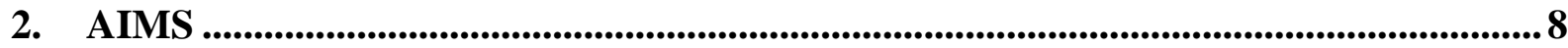

3. MATERIALS AND METHODS .............................................................................9

3.1. Gender- and age-specific utilisation study of anti-osteoporotic drugs ......................... 9

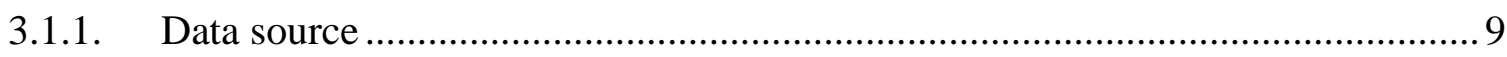

3.1.2. Database screening for anti-osteoporotic medications ................................... 9

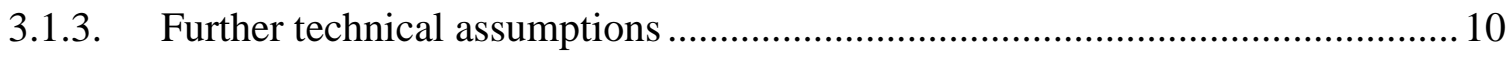

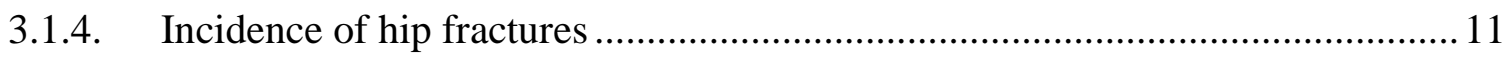

3.2. Medication use and fall prevalence among nursing home residents .......................... 12

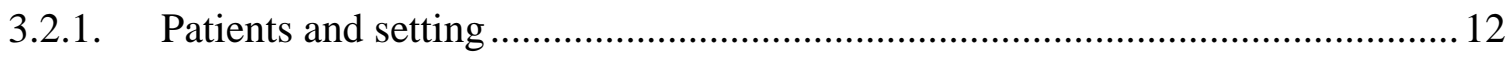

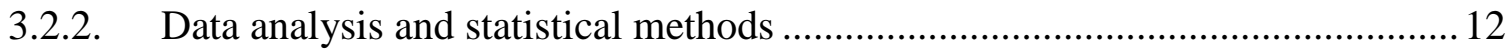

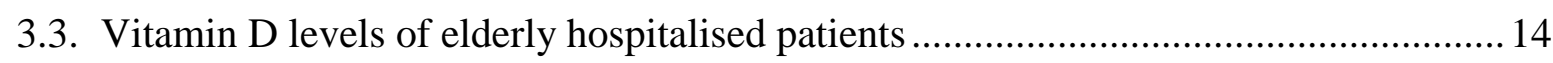

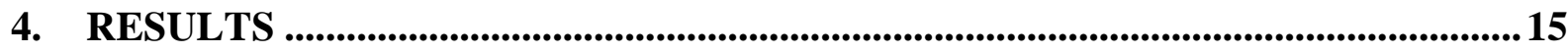

4.1. Gender- and age-specific utilisation study of anti-osteoporotic drugs ....................... 15

4.1.1. Gender- and population-based results ........................................................ 15

4.1.2. Gender- and age-standardised results ...................................................... 18

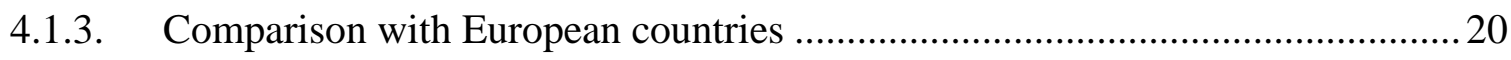

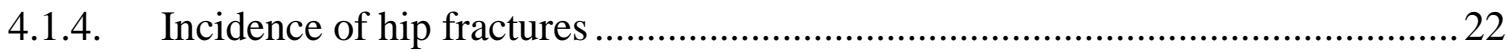

4.2. Medication use and fall prevalence among nursing home residents ......................... 23

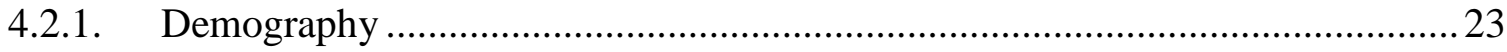

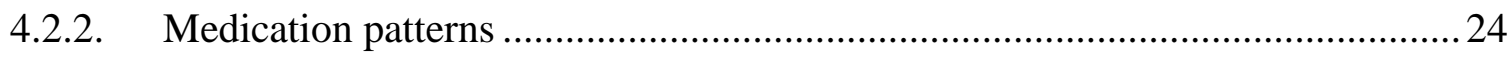

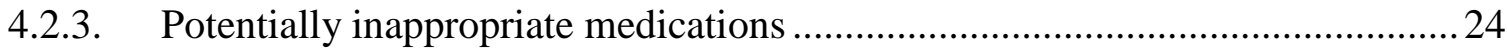

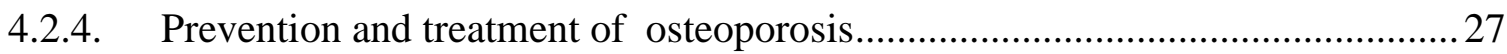

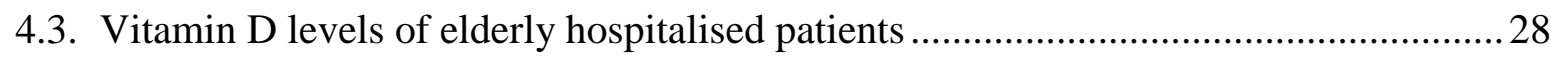

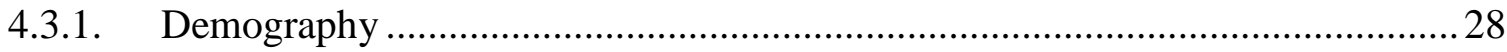

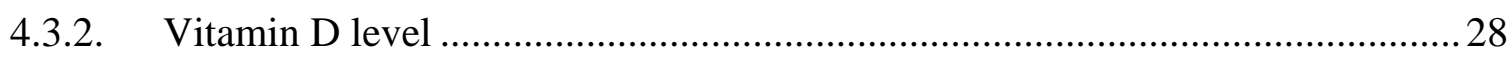

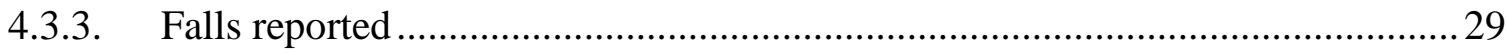




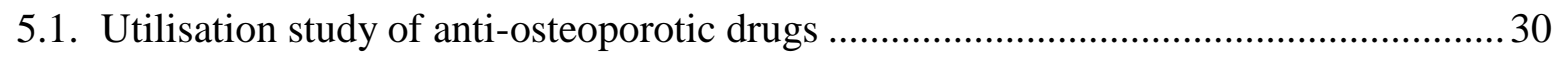

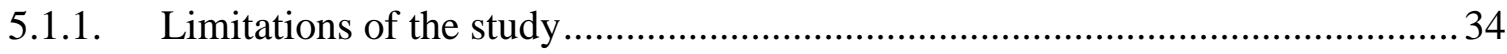

5.2. Medication use and fall prevalence among nursing home residents ............................. 34

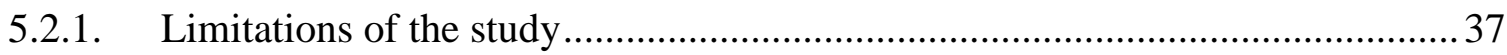

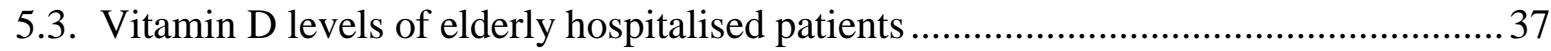

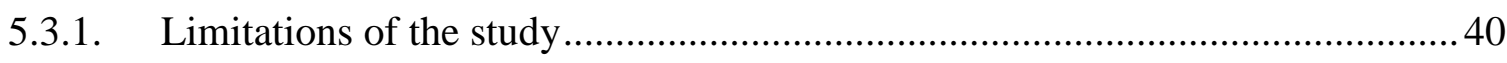

6. SUMMARY AND CONCLUSIONS ...............................................................................41

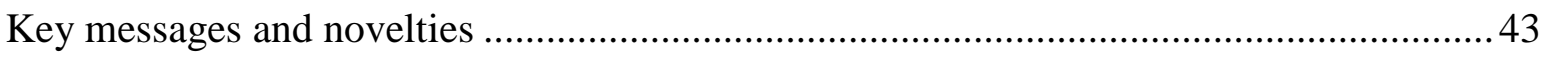

7. ACKNOWLEDGEMENTS................................................................................................... 44

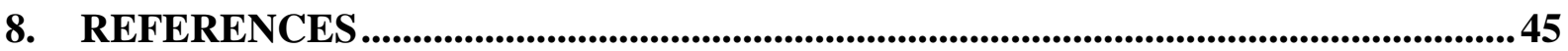




\section{GLOSSARY OF ABBREVIATIONS}

\begin{tabular}{|c|c|}
\hline ADR & Adverse drug reaction \\
\hline ATC & Anatomical therapeutic chemical classification system \\
\hline BMD & Bone mineral density \\
\hline BRONJ & Bisphosphonate-related osteonecrosis of the jaw \\
\hline $\mathrm{CDC}$ & Centers for Disease Control and Prevention \\
\hline $\mathrm{CI}$ & Confidence interval \\
\hline DDD & Defined daily dose \\
\hline DEXA & Dual-energy X-ray absorptiometry \\
\hline EMA & European Medicines Agency \\
\hline ENDO & Endocrine Society \\
\hline FDA & Food and Drug Administration \\
\hline FRAX & Fracture risk assessment tool \\
\hline $\mathrm{HCSO}$ & Hungarian Central Statistical Office \\
\hline HR & Hazard ratio \\
\hline HUF & Hungarian forints \\
\hline ICD & International classification of diseases \\
\hline IOF & International Osteoporosis Foundation \\
\hline IU & International unit \\
\hline NHANES & National health and nutrition examination survey \\
\hline NHIF & National Health Insurance Fund \\
\hline NNH & Number needed to harm \\
\hline NOS & National Osteoporosis Society \\
\hline OP & Osteoporosis \\
\hline OR & Odds ratio \\
\hline OTC & Over the counter \\
\hline
\end{tabular}


PIM Potentially inappropriate medication

PP Polypharmacy

PPV Positive predictive value

SD Standard deviation

SPC Summary of product characteristics

TID Thousand inhabitants per day

USPTF U.S. Preventive Services Task Force

UVB Ultraviolet radiation B

WHO World Health Organisation 


\section{LIST OF PAPERS INCLUDED IN THE THESIS}

1. Andrea Bor, Mária Matuz, Nóra Gyimesi, Zsuzsanna Biczók, Gyöngyvér Soós, Péter Doró: Gender inequalities in the treatment of osteoporosis.

MATURITAS 80: pp. 162-169. (2015)

2. Andrea Bor, Mária Matuz, Márta Csatordai, Gábor Szalai, András Bálint, Ria Benkő, Gyöngyvér Soós, Péter Doró: Medication use and risk of falls among nursing home residents: a retrospective cohort study.

INTERNATIONAL JOURNAL OF CLINICAL PHARMACY

39: (2) pp. 408-415. (2017)

3. Bor A, Matuz M, Doro P, Viola R, Soos G. Drug-related problems in the elderly. (Az időskori gyógyszeralkalmazás problémái. Article in Hungarian.)

ORVOSI HETILAP 153: (49) pp. 1926-1936. (2012)

4. Bor Andrea, Matuz Mária, Doró Péter, Soós Gyöngyvér:

Potentially inappropriate medication among the elderly. (Idősek gyógyszerelése: kockázatot jelentő hatóanyagok. Article in Hungarian.) GYÓGYSZERÉSZET 57: (3) pp. 131-135. (2013) 


\section{INTRODUCTION}

Geriatric falls are the leading causes of hospital trauma admissions and injury-related deaths among older adults [1, 2]. Approximately one-third of community-dwelling elderly above the age of 65 fall at least once a year, resulting in bone fractures, worsened quality of life, loss of independence, fear of falling, disability and early death [3, 4].

Population aging is a well-documented, growing problem in developed countries nowadays. The proportion of older adults is remarkably increasing; it is estimated that the number of people over 60 years will rise from 901 million in 2015 to 2.1 billion by the year 2050 [5]. For example, in Hungary this age group will increase from $24.9 \%$ to $34.6 \%$ between the years 2015 and 2050, but in China the rate will double (Figure 1).

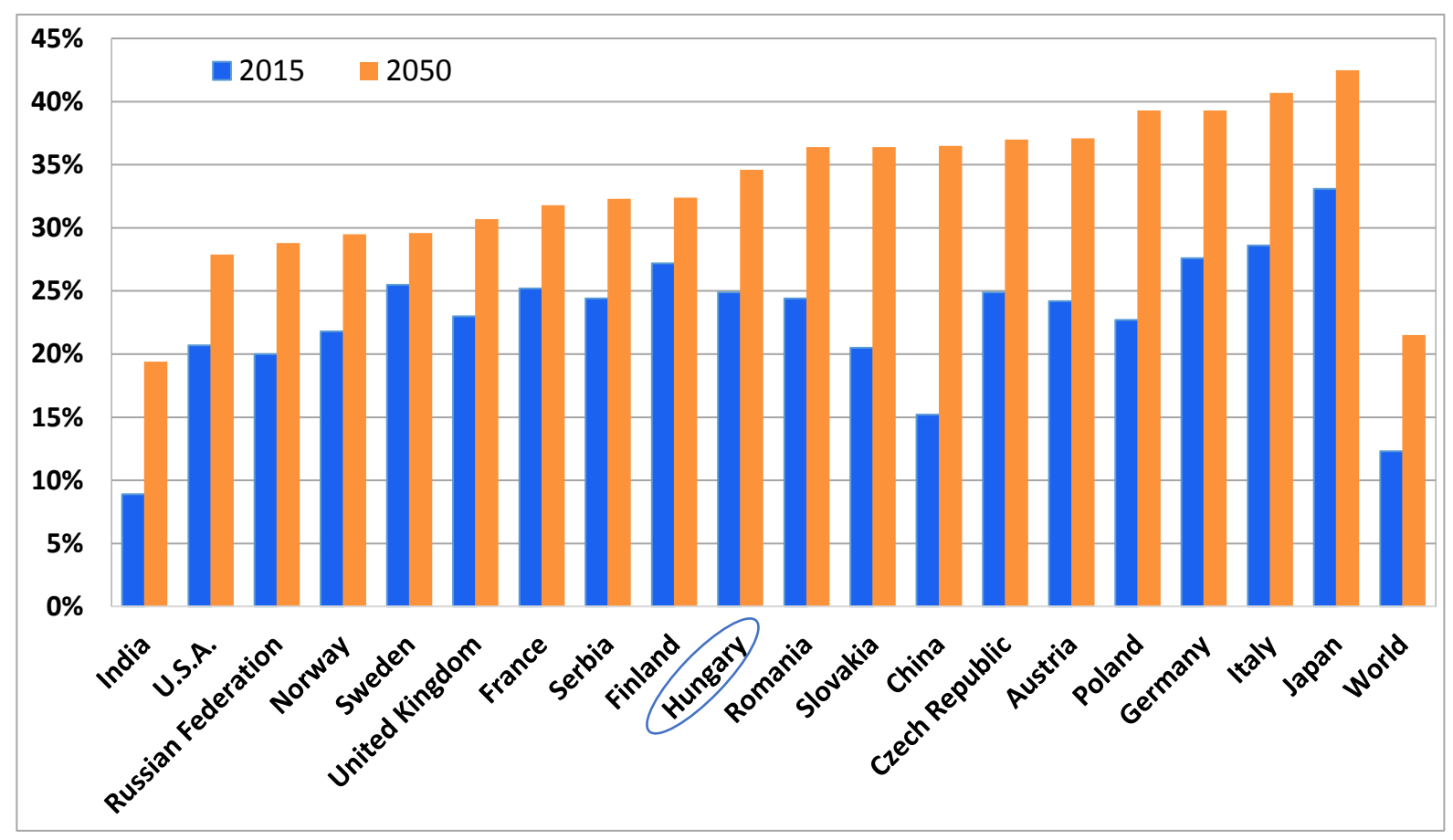

Figure 1 Percentage distribution of the 60+ age group by country in 2015 and 2050 [5]

Among the elderly, medication use is a crucial element among extrinsic risk factors for falls [6]. It is proven and well known that older people account for the highest proportion of medication costs, as the number of chronic diseases rapidly increases with age [6, 7]. Even though comorbidities in older people often require taking numerous prescription drugs, taking 4 or more chronic medications (defined as polypharmacy) was found to be an independent risk factor for falls [8,9]. Polypharmacy (PP) also increases the prevalence of drug-related problems, such as drug-drug interactions, adverse drug reactions, prescription errors and non-adherence $[10,11]$. Though there is no consensus about the exact cut-off value 
for polypharmacy, usually it is defined as the concomitant use of more than or equal to 4-8 chronic medications $[6,12,13]$. Polypharmacy is quite common in geriatric patients: the prevalence in the U.S. is around 57\%, while a large European study reported $39.4 \%$ above the age of $65[14,15]$. To reduce the risk of falls and to minimize the prevalence of adverse drug reactions, potentially inappropriate medication (PIM) lists have been implemented, among which the 'Beers criteria' is the most widely used, outstarter list [16]. Initially its use was restricted for nursing home residents, then it was extended for any geriatric patients. The most recently updated (2015) list identifies not only the potentially inappropriate drugs, but also offers recommendation on alternative medications or therapies [17]. Following the Beers criteria, numerous countries have created their specific national PIM list, adding or withdrawing medications, adapted to the country's therapeutic practice and pharmaceutical market. Using these medication lists is a substantial strategy to reduce the risk of adverse events and falls in older adults, however, the lists are hardly confirmed by real epidemiological data. According to the Centers for Disease Control and Prevention (CDC), approximately $5 \%$ of adults above 65 years live in nursing homes, but these residents account for about $20 \%$ of deaths from falls in this age group [1]. Although many falls remain unreported, patients often fall more than once a year. In a typical nursing home, the annual average number of falls is 2.6 per patient [1]. Therefore guidelines and policies on fall prevention need to be adverted on populations under the greatest risk, such as nursing home residents.

Other than medication use, many studies have revealed a variety of factors or conditions that can increase the risk of falling in elderly patients, such as older age, comorbidities, vitamin D deficiency, vision disturbances, diabetes, depression and osteoporosis $[6,8,18]$. In the present thesis, osteoporosis and serum vitamin D level have been studied as risk factors for falls (and fractures).

Osteoporosis (OP) is a metabolic bone disease, characterised by decreased bone mass, quality and strength, and increased susceptibility to fracture, even to minimal trauma (such as falls) (Figure 2) [19]. Therefore osteoporotic patients with brittle bones are under high risk of developing low-energy fractures - as a consequence of falls. Thus, prevention and treatment of osteoporosis is an important challenge, which cannot be accomplished without identifying the population at greatest risk. 

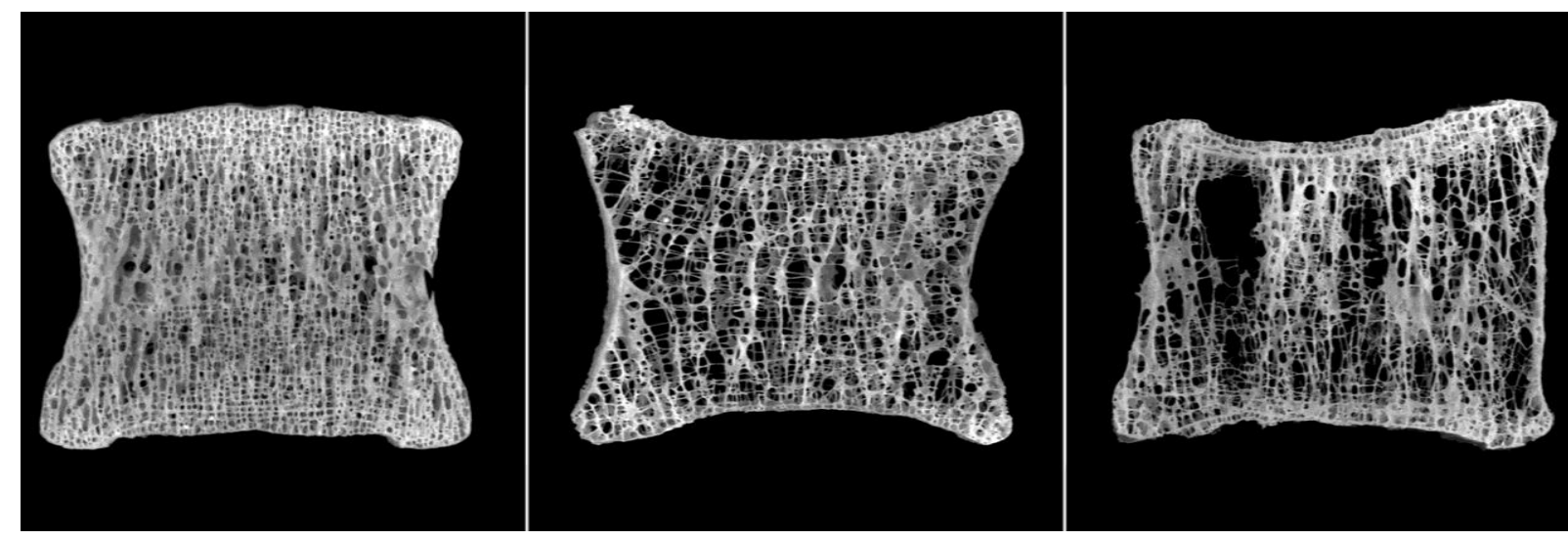

Figure 2 This three-dimensional photographic study shows the progression of vertebral body from normal bone density to moderate osteoporosis and severe osteoporosis [20]. (Permission to use images granted by Professor Alan Boyde.)

The incidence of OP increases with age, occurring mainly above the age of 50 years. In Germany, $6.3 \%$ of the population (around five million patients) were diagnosed with osteoporosis in 2009, reported by a recently published epidemiologic study [21]. Osteoporosis is mostly defined as the disease of women, because the prevalence and fracture rates are much higher among females. However, the disease affects a significant portion of men, as well. From the 10 million residents of Hungary, it is estimated that in the population over 50 years of age 547,107 people suffered from osteoporosis, of which 94,949 were males and 452,158 were females in 2010 [22, 23]. Similar prevalence rates were found in the European Union, while the rate was higher in the U.S.A. [18, 22, 23]. Amongst fall-related low-energy bone fractures, hip fractures are the most significant consequences of osteoporosis: they put a huge financial burden on the health care system and on the patients as well, besides extreme pain and high morbidity and mortality rates.

These types of fractures require urgent surgical intervention, hospitalisation and prolonged rehabilitation, yet nearly $25 \%$ of people with hip fracture will die within one year. Although falls and fractures are more common among older women than men, in the case of hip fracture the mortality rate is almost double in males than in females: $26.8-32.5 \%$ versus 17.0-21.9\% [18, 22-32]. There are approximately 100,000 osteoporotic bone fractures each year in Hungary, and the treatment costs are estimated to be more than 20 billion HUF (Hungarian Forints, about 64.5 million EUR) for the National Health Insurance Fund (NHIF) in 2011. At the same time, the expenses of pharmacological prevention and treatment take only 8 billion HUF (26 million EUR), moreover, 50\% of osteoporotic fractures would be preventable with appropriate pharmacological treatment and with screening the population at risk [33]. 
Besides osteoporosis, many studies have proven that low vitamin D level increases the risk of bone fractures. Adequate vitamin D level is essential to prevent bone loss and structural damage of the bone matrix, which also prevents fractures. Though there are insufficient data to confirm a causal relationship between vitamin D deficiency and the immune, cardiovascular, and metabolic systems, many epidemiological studies proved that low levels of vitamin D are important risk factors in several diseases, such as diabetes, cardiovascular diseases, hypertension, cancer or in autoimmune diseases [34-38]. Low vitamin D levels are also associated with decreased muscle strength and coordination, which can lead to falls $[39,40]$. 


\section{AIMS}

Our objective was to identify the main risk factors of geriatric falls on different population levels.

a) A gender- and age-specific analysis was performed regarding the utilisation of antiosteoporotic drugs on national level in Hungary, covering a 5-year period (between 2007 and 2011). Further goals were to analyse the differences of treatment characteristics and hip-fracture trends between males and females, and to compare our results with those in other European countries.

b) Secondly, our aim was to evaluate the medication use of nursing home residents by using the Hungarian PIM list - created and developed by our research group-, as well as to investigate the possible predictors of geriatric falls annualised over a 5-year-long period (between 2011 and 2015), under the frame of a cohort study.

c) Finally, in a pilot study, we compared vitamin D levels of elderly, hospitalised hip fractured patients with hospitalised non-fractured patients. Additionally, the prevalence of falls was detected and the differences between the groups were analysed. 


\section{MATERIALS AND METHODS}

\subsection{Gender- and age-specific utilisation study of anti-osteoporotic drugs}

\subsubsection{Data source}

The source of our crude data was the Hungarian National Health Insurance Fund (NHIF), which is the sole, mandatory, national health insurance fund, covering $100 \%$ of the Hungarian population (roughly 10 million people). All prescription claims are recorded by the providers; the NHIF database contains data on age, gender, residence, date of claim, medication, and diagnosis by ICD codes (International Classification of Diseases, 2010) [41]. Microsoft Access and Microsoft Excel programs were used for data management and analysis. For our study the NHIF provided anonymous, aggregated crude data; therefore this study did not require ethical approval.

Our data for the European comparison came from the Estonian State Agency of Medicines, from the Baltic Statistics on Medicines, the Finnish Medicines Agency Fimea and Social Insurance Institution, and from the Norwegian Prescription Database [42-47]. All results refer to the total population of each country.

\subsubsection{Database screening for anti-osteoporotic medications}

A retrospective analysis was performed regarding anti-osteoporotic medication use in Hungary, for the period between 2007 and 2011. The following details on medication use were available in the crude data: calendar year (2007-2011), gender, age group (in 5-year-long clusters), ATC code (Anatomical Therapeutic Chemical Classification), active pharmaceutical ingredient, product name, strength, ICD code (first 3 digits), number of packaging units, number of patients, and total number of DDDs (Defined Daily Dose). The primary screening method was based on the ATC codes (2013 version) of drugs [48]. ATC is a pharmaceutical, five-level, seven digit coding system. Active substances are divided into different groups according to the organ or system on which they act and to their therapeutic and chemical characteristics [48]. The ATC/DDD system was set up by the World Health Organisation (WHO), in order to serve as a tool for drug utilisation research, and to improve quality of drug use [49]. 
The screened drugs that are available for the treatment of osteoporosis in Hungary were the followings: vitamin D and analogues (ATC: A11CC02-05), calcium compounds (A12AA03-04, and A12AA13), bisphosphonates (M05BA02-08), bisphosphonate combinations (M05BB03-05), strontium ranelate (M05BX03), and denosumab (M05BX04). The DDD is the average maintenance daily dose of the medication used for its main therapeutic indication in adults [49]. The medication use of large populations is often expressed as the number of DDDs per 1000 inhabitants per day, which technical unit enables to compare the drug use of populations of different sizes [50]. To obtain standardised, DDD/1000 inhabitants/day (DDD/TID) unit, we calculated with the formula below:

$$
\mathrm{DDD} / \mathrm{TID}=\mathrm{DDD} / 365 / \text { population size } \mathrm{x} 1000 \text {. }
$$

Drug utilisation data expressed in this way may provide a rough estimate of the proportion of the population treated daily with certain drugs. An estimated drug consumption of $10 \mathrm{DDD} / 1000$ inhabitants/day corresponds to a daily use of the investigated drug by $1 \%$ of the population within a defined area [46].

For each year, the gender and age-standardised data on population size were gained from the Hungarian Central Statistical Office (HCSO) [51]. The youngest population receiving anti-osteoporotic treatment was the 40-44-year-old group. In 2007 the total Hungarian population was $10,055,783$ inhabitants, out of which there were 4,928,988 people above the age of 40 years (2,158,031 males and 2,770,967 females), while in 2011 the total population was 9,971,727 inhabitants, out of which 5,010,276 people were above the age of 40 years $(2,201,817$ males and 2,808,459 females) [51]. The secondary screening method was based on the indications of drugs, coded by ICD (included ICDs: E55-58, M80, M81).

\subsubsection{Further technical assumptions}

a) In the case of bisphosphonate combinations (alendronic acid + vitamin D, M05BB03, alendronic acid + vitamin D + calcium, M05BB05, risedronic acid + vitamin D + calcium, M05BB04) different vitamin D and calcium doses were found from those in the vitamin D and calcium monotherapy medications. Therefore, direct comparison on each vitamin D and calcium-containing medications was not possible, since DDD/TID values were also different in the combinations. These categories are presented separately. 
b) To avoid any bias, drugs for the treatment of malignancies (ICD "C" group and M82, M85) were excluded from the final analysis. The rates of excluded drugs (expressed in DDD\%) in the indication of cancer therapy were the followings: vitamin $\mathrm{D}$ and analogues $1.38 \%$, calcium compounds $2.64 \%$, bisphosphonates $8.34 \%$, bisphosphonate combinations $0.12 \%$, denosumab and strontium ranelate less than $0.1 \%$, all of which was roughly $3 \%$ of treated patients.

\subsubsection{Incidence of hip fractures}

Age- and gender-specific incidence of hip fractures was studied in 2007 and 2011 in Hungary. Our crude data came from the "Tables of basic data on Hungarian health care" [52]. Hip fractures were identified according to ICD codes (S72.0, S72.1, and S72.2) (Figure 3).
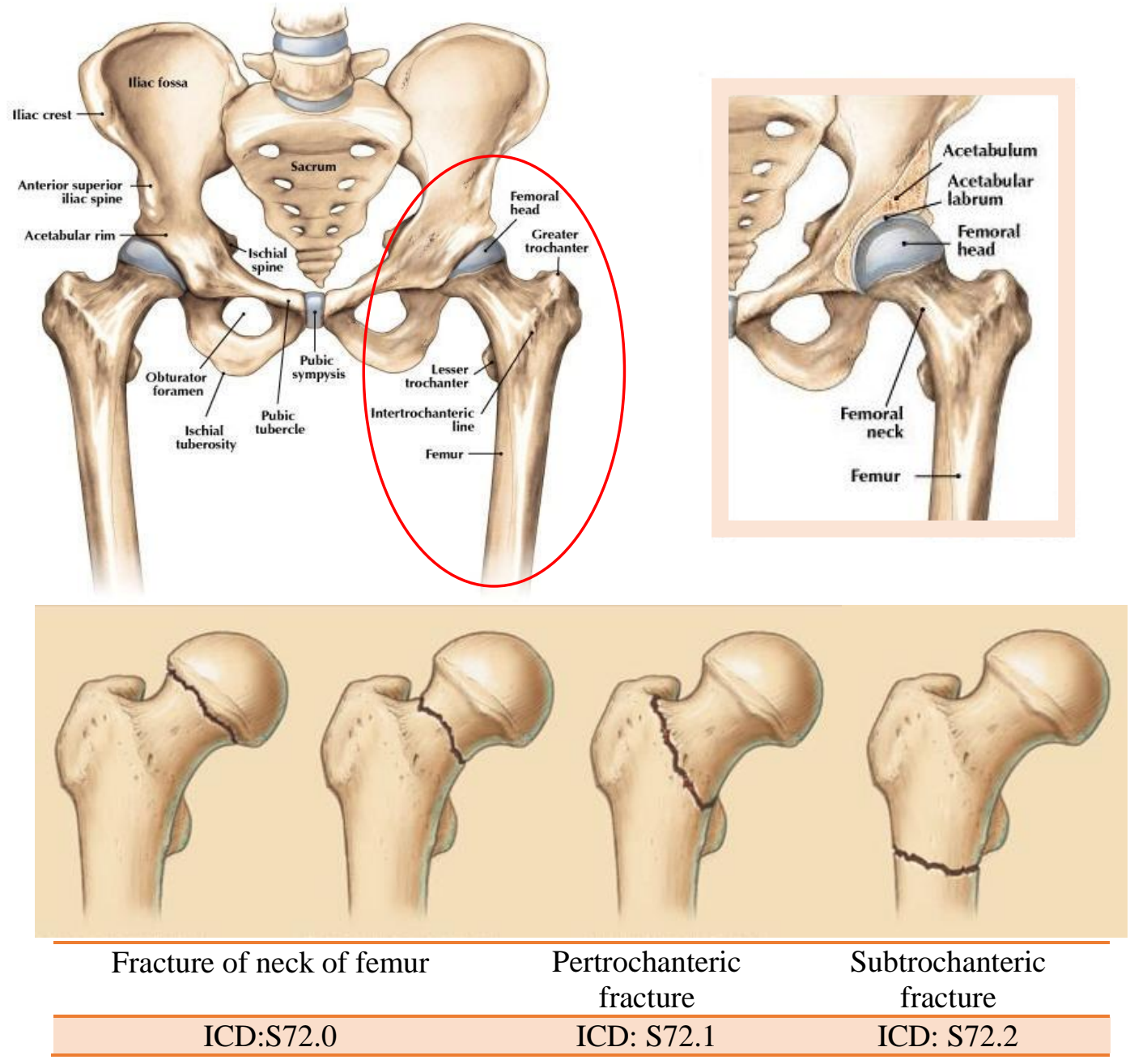

Figure 3 Anatomy of pelvis and hip and different types of hip fractures [53] 


\subsection{Medication use and fall prevalence among nursing home residents}

A retrospective analysis was performed regarding the medication use and fall prevalence in nursing home residents, all recruited from the same institution, between August 2011 and August 2015 in Szeged, Hungary.

\subsubsection{Patients and setting}

Every patient who was the resident of the investigated nursing home for at least 12 months was included in the study. Patient data were recorded and analysed for the first 12 months of residency, starting from the date of admission. Relevant medication lists and demographic information were collected from the patient medical documentation of the facility. Detailed data on falls were available from hospital discharge documents since, after noticed falls, all residents were admitted to hospital for further investigation according to the nursing home protocol. The nursing home provides residential accommodation, meals and 24-hour personal care (residential nursing) for those who find it difficult to cope without assistance. The facility is fully accessible and barrier-free. Daily medical supervision is also ensured (neurologist and gerontologist). Due to the local policy, deceased patients were excluded from this study, since we had no data access to those patients' medical information. The present study was approved by the Regional Human Biomedical Research Ethics Committee of the University of Szeged.

\subsubsection{Data analysis and statistical methods}

Microsoft Excel, IBM SPSS Statistics (version 23) and R (3.2.2) programs were used for data management and analysis. A Chi-squared test was applied to compare the categorical variables (e.g. gender) between the investigated groups, and Fisher's test in case of polypharmacy. Student's t-test was performed to compare the continuous variables (e.g. age, number of medications) between groups.

\section{Positive predictive value (PPV)}

We examined the prevalence and PPV with 95\% confidence intervals (CI 95\%), to estimate the possible impact of each medication (active substance) on risk of falls by the widely used, basic architecture ( 2 by 2 contingency table) of cohort studies [54]. PPV is the proportion of patients taking a particular (investigated) drug and who had fall(s). In other words it shows the probability of an outcome (fall) if the patient has the tested condition (takes the particular drug). These proportions only have limited validity in clinical practice, 
however. The predictive values of a clinical test depend critically on the prevalence of the condition (falls) in the patients being tested within a particular environment [55].

\section{Number needed to harm (NNH)}

NNH was calculated for those active agents which had high PPV, and where the lower CI 95\% value exceeded the annual fall prevalence rate. The NNH index expresses how many patients need to be exposed to a certain risk-factor (drug) to cause harmful effect (fall) in one patient over a specific time period (1 year) $[56,57]$. Nevertheless, $\mathrm{NNH}$ values calculated in our study cannot be extended for the entire population of elderly people; they are valid only for those nursing home residents involved in this analysis.

\section{Binary logistic regression analysis}

Binary logistic regression analysis was carried out to determine the association of falls with other variables found significant in univariate analysis. Logistic regression was characterised by the accuracy of test $[56,57]$.

\section{Potentially inappropriate medications}

To identify the potentially inappropriate medications, four commonly used PIM lists have been adopted to the Hungarian drug market and to our data on medication use, i.e. the updated Beers criteria (2015), the French LaRoche list (2007), the German Priscus list (2010) and the Austrian Mann list (2012) [17, 58-60]. The adopted list consists of 94 drugs or active ingredients (PIMs), out of which 54 drugs (PIM fall risk) were considered high-risk drugs in terms of falls (based on the rationale of the original lists) [61]. The prevalence of exposure to these medicines was illustrated by Venn diagram [62]. The complete Hungarian PIM list can be found as a supplement of this thesis. 


\subsection{Vitamin D levels of elderly hospitalised patients}

A prospective pilot study was done to compare vitamin D levels of hospitalised hip fractured patients with hospitalised non-fractured patients in Szeged, Hungary. The fractured group was recruited from the Traumatology Department and the control group was recruited from the Department of Internal Medicine and Geriatrics. The recruitment period was from 2011 June to 2011 September. Control group was matched according to age and gender. Microsoft Excel and R (3.2.2) programs were used for data management and analysis. Student's t-test was performed to compare the continuous variables (e.g. age, vitamin D level) between groups.

An international consent uses $25(\mathrm{OH}) \mathrm{D}_{3}$ (cholecalciferol) as a reference to assess the general level of vitamin D in the body (Table 1). The normal blood level of vitamin D is between 30 and $40 \mathrm{ng} / \mathrm{ml}$, and this range is also considered as laboratory reference range [63]. Cholecalciferol levels were measured with ELISA kit and were expressed in ng/ml. All hip fractures derived from falls; therefore fall prevalence rate was considered $100 \%$ in the fractured group. Subjects were asked about previous falls during a personal interview. The study was approved by the Regional Human Biomedical Research Ethics Committee of the University of Szeged.

Table 1 Laboratory references of $25(\mathrm{OH}) \mathrm{D}_{3}$ vitamin (*based on national guidelines, this rate may vary in different countries) [63]

\begin{tabular}{|c|l|}
\hline \multicolumn{2}{|c|}{ Laboratory references of $25(\mathrm{OH}) \mathrm{D}_{3}$ vitamin* } \\
\hline above $30 \mathrm{ng} / \mathrm{ml}($ above $75 \mathrm{nmol} / \mathrm{L})$ & Sufficiency (adequately supplied) \\
\hline$<30 \mathrm{ng} / \mathrm{ml}(<75 \mathrm{nmol} / \mathrm{L})$ & Insufficiency (deficient) \\
\hline$<20 \mathrm{ng} / \mathrm{ml}(<\mathbf{5 0} \mathbf{n m o l} / \mathrm{L})$ & Deficiency (seriously deficient) \\
\hline
\end{tabular}




\section{RESULTS}

\subsection{Gender- and age-specific utilisation study of anti-osteoporotic drugs}

\subsubsection{Gender- and population-based results}

As expected, medication use by females was substantially higher in the case of every medication than by males (Figure 4). During the examined 5-year period, the utilisation of vitamin D and analogues showed constant increase from 7.91 DDD/TID to 13.73 DDD/TID (Table 2). A similar tendency was revealed in female and male patients. However, there was an approximately ten-fold difference between genders, male patients were remarkably undertreated. Vitamin D can also be found in combination with bisphosphonates, therefore the overall consumption was higher. The utilisation of calcium compounds increased from $1.43 \mathrm{DDD} / \mathrm{TID}$ in 2007 to $4.49 \mathrm{DDD} / \mathrm{TID}$ in 2011, which is a more than three-fold growth. This tendency mainly arose from the treatment of female patients; males were significantly undertreated (F:M ratio was 10.8 in 2011). As calcium occurs in combination with alendronic and risedronic acid, the total rate would be higher than above.

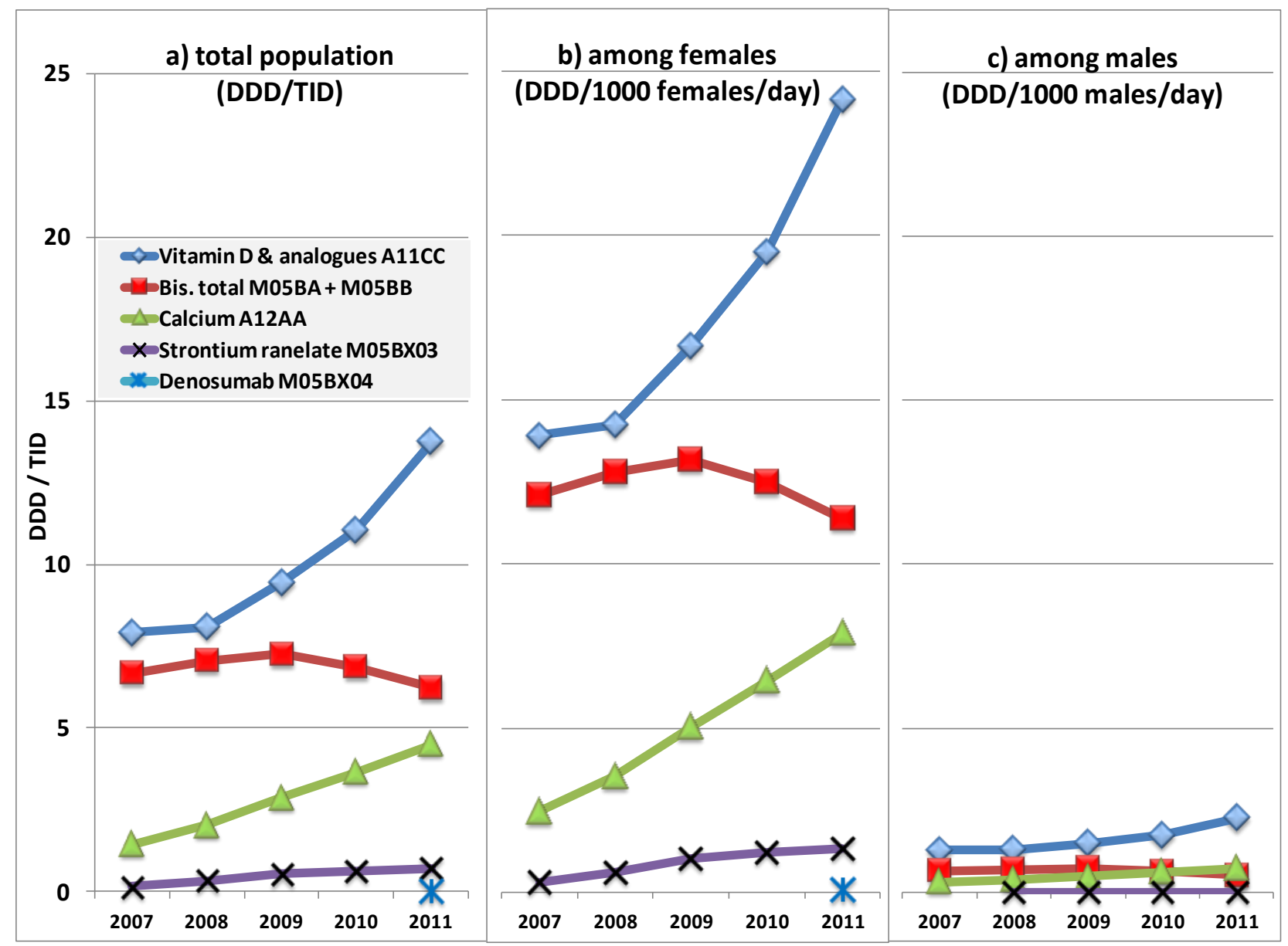

Figure 4 Utilisation of anti-osteoporotic medications in Hungary 2007-2011 
Table 2 Gender-standardised utilisation of anti-osteoporotic drugs between 2007 and 2011 in Hungary

(Bis. = Bisphosphonate $\mathrm{F}=$ female $; \mathrm{M}=$ male $)$

\begin{tabular}{|c|c|c|c|c|c|c|c|c|c|c|c|c|c|c|c|}
\hline Utilisation & Drug & $\begin{array}{c}\text { Vitamin D } \\
\& \\
\text { analogues }\end{array}$ & Calcium & Bis. total & $\begin{array}{c}\text { Bis. } \\
\text { mono- } \\
\text { therapy }\end{array}$ & $\begin{array}{l}\text { Bis. } \\
\text { combi- } \\
\text { nations }\end{array}$ & $\begin{array}{l}\text { Alendronic } \\
\text { acid }\end{array}$ & $\begin{array}{c}\text { Ibandronic } \\
\text { acid }\end{array}$ & $\begin{array}{l}\text { Risedronic } \\
\text { acid }\end{array}$ & $\begin{array}{l}\text { Zoledronic } \\
\text { acid }\end{array}$ & $\begin{array}{c}\text { Alendronic } \\
\text { acid + } \\
\text { Vitamin D }\end{array}$ & $\begin{array}{c}\text { Risedronic } \\
\text { acid + } \\
\text { Vitamin D } \\
+ \text { Calcium }\end{array}$ & $\begin{array}{c}\text { Alendronic } \\
\text { acid + } \\
\text { Vitamin D } \\
+ \text { Calcium }\end{array}$ & $\begin{array}{c}\text { Strontium } \\
\text { ranelate }\end{array}$ & $\begin{array}{c}\text { Denosu- } \\
\text { mab }\end{array}$ \\
\hline DDD/TID & $\begin{array}{l}\text { ATC/ } \\
\text { Years }\end{array}$ & A11CC & A12AA & $\begin{array}{c}\text { M05BA + } \\
\text { M05BB }\end{array}$ & M05BA & M05BB & M05BA04 & M05BA06 & M05BA07 & M05BA08 & M05BB03 & M05BB04 & M05BB05 & M05BX03 & M05BX04 \\
\hline \multirow[t]{5}{*}{ Total } & 2007 & 7.91 & 1.43 & 6.66 & 5.07 & 1.60 & 3.91 & 0.68 & 0.48 & - & 0.81 & 0.69 & 0.10 & 0.16 & - \\
\hline & 2008 & 8.09 & 2.03 & 7.04 & 4.24 & 2.80 & 3.30 & 0.79 & 0.14 & $<0.01$ & 1.42 & 1.27 & 0.11 & 0.32 & - \\
\hline & 2009 & 9.44 & 2.87 & 7.27 & 3.88 & 3.39 & 2.75 & 0.99 & 0.14 & $<0.01$ & 2.02 & 1.23 & 0.14 & 0.54 & - \\
\hline & 2010 & 11.05 & 3.66 & 6.85 & 3.58 & 3.28 & 2.25 & 1.12 & 0.21 & $<0.01$ & 2.08 & 1.05 & 0.15 & 0.64 & - \\
\hline & 2011 & 13.73 & 4.49 & 6.22 & 3.42 & 2.81 & 1.94 & 1.11 & 0.37 & $<0.01$ & 1.89 & 0.77 & 0.14 & 0.70 & 0.04 \\
\hline \multirow[t]{5}{*}{ Female } & 2007 & 13.91 & 2.45 & 12.10 & 9.13 & 2.97 & 6.94 & 1.29 & 0.91 & - & 1.48 & 1.31 & 0.18 & 0.31 & - \\
\hline & 2008 & 14.23 & 3.52 & 12.78 & 7.62 & 5.16 & 5.84 & 1.51 & 0.27 & $<0.01$ & 2.55 & 2.41 & 0.20 & 0.61 & - \\
\hline & 2009 & 16.62 & 5.04 & 13.18 & 6.98 & 6.20 & 4.83 & 1.88 & 0.26 & $<0.01$ & 3.62 & 2.33 & 0.25 & 1.03 & - \\
\hline & 2010 & 19.48 & 6.43 & 12.49 & 6.49 & 6.00 & 3.96 & 2.13 & 0.39 & $<0.01$ & 3.77 & 1.97 & 0.26 & 1.21 & - \\
\hline & 2011 & 24.13 & 7.89 & 11.39 & 6.26 & 5.14 & 3.46 & 2.12 & 0.67 & $<0.01$ & 3.43 & 1.45 & 0.26 & 1.34 & 0.08 \\
\hline \multirow[t]{5}{*}{ Male } & 2007 & 1.28 & 0.30 & 0.65 & 0.57 & 0.08 & 0.56 & $<0.01$ & $<0.01$ & - & 0.07 & 0.01 & $<0.01$ & $<0.01$ & - \\
\hline & 2008 & 1.30 & 0.38 & 0.69 & 0.50 & 0.19 & 0.50 & $<0.01$ & $<0.01$ & - & 0.18 & 0.01 & $<0.01$ & $<0.01$ & - \\
\hline & 2009 & 1.49 & 0.48 & 0.73 & 0.45 & 0.28 & 0.44 & $<0.01$ & 0.01 & - & 0.24 & 0.02 & 0.02 & $<0.01$ & - \\
\hline & 2010 & 1.73 & 0.61 & 0.63 & 0.37 & 0.26 & 0.35 & - & 0.02 & $<0.01$ & 0.20 & 0.03 & 0.02 & $<0.01$ & - \\
\hline & 2011 & 2.25 & 0.73 & 0.51 & 0.28 & 0.23 & 0.26 & - & 0.03 & $<0.01$ & 0.19 & 0.02 & 0.02 & $<0.01$ & - \\
\hline \multirow[t]{5}{*}{ F:M ratio } & 2007 & 10.90 & 8.10 & 18.60 & 16.00 & 37.60 & 12.30 & 294.50 & 236.70 & - & 22.00 & 134.50 & 93.40 & 741.70 & - \\
\hline & 2008 & 11.00 & 9.20 & 18.40 & 15.20 & 26.50 & 11.70 & 1105.60 & 380.40 & - & 14.20 & 198.10 & 59.10 & 239.90 & - \\
\hline & 2009 & 11.10 & 10.50 & 18.10 & 15.50 & 22.30 & 10.90 & 1789.20 & 37.60 & - & 14.90 & 130.90 & 15.30 & 297.90 & - \\
\hline & 2010 & 11.30 & 10.60 & 19.90 & 17.70 & 23.00 & 11.30 & - & 24.50 & 55.20 & 18.40 & 57.20 & 12.30 & 304.30 & - \\
\hline & 2011 & 10.70 & 10.80 & 22.20 & 22.10 & 22.40 & 13.50 & - & 24.30 & 47.10 & 18.10 & 68.00 & 14.00 & 372.30 & - \\
\hline
\end{tabular}


The total bisphosphonate use was 6.66 DDD/TID in 2007, it slowly increased in 2008 and 2009, but for 2011 it dropped to 6.22 DDD/TID. Male patients were treated approximately 20 times less than women (F:M ratio was 22.2 in 2011).

In 2007 , monotherapy took roughly $75 \%$ of the total trade compared to $55 \%$ in 2011 , since the use of bisphosphonate combinations gradually increased, and nearly reached the rate of monotherapy in females and in males as well (Figure 5). The most widely used agent was alendronic acid; however, during the 5-year-long period, the trade of alendronic acid in monotherapy halved (3.91 vs 1.94 DDD/TID), while the combination with vitamin D more than doubled (0.81 vs $1.89 \mathrm{DDD} / \mathrm{TID})$. The trade of vitamin $\mathrm{D}$ and calcium combination with alendronic acid was 0.15 DDD/TID in 2011. Alendronic acid took almost two-third of the total bisphosphonate use in all investigated years. The use of risedronic acid was more or less constant. The rate of combination with vitamin $\mathrm{D}$ and calcium was double compared to monotherapy (0.37 vs 0.77 DDD/TID in 2011). It accounted for roughly one-fifth of all bisphosphonate trade in all years. Ibandronic acid took around 16\% (1.11 DDD/TID in 2011) of the total bisphosphonate consumption, and it was prescribed only for women; in 2010 and in 2011 there was no use of it in the male population. Zoledronic acid use has remained marginal since 2007 on the Hungarian market with less than 0.01 DDD/TID.

Strontium ranelate is mainly prescribed for women after the bisphosphonate therapy failed or could not be tolerated. The trade showed a constant increase since 2007 (0.16 DDD/TID), for 2011 it reached 0.70 DDD/TID.

Denosumab, a monoclonal antibody, was introduced to the Hungarian market in 2011 and took $0.04 \mathrm{DDD} / \mathrm{TID}$ in that year. 


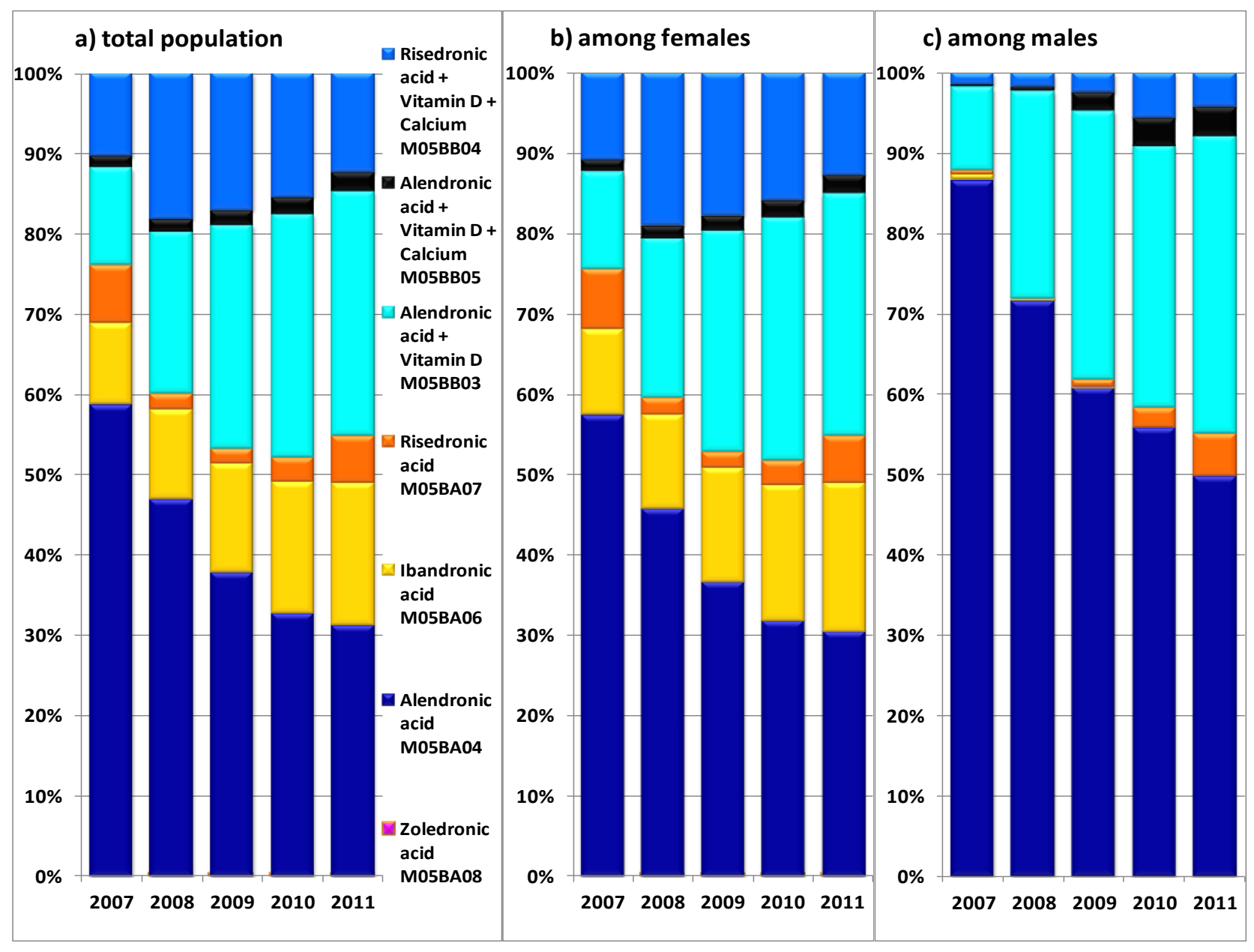

Figure 5 Utilisation rate of bisphosphonates in Hungary 2007-2011

\subsubsection{Gender- and age-standardised results}

The utilisation of bisphosphonates was the highest in the 75-79-year-old population in both genders, but with very different values: 49.27 DDD/1000females/day and 3.40 DDD/1000males/day in 2011 (Table 3). The highest decrease in bisphosphonate utilisation was detected in the 40-54 age groups in both genders during the study period. The largest differences between genders could be seen in 2011 in all age groups. Strontium ranelate was prescribed to male patients only above the age of 60 , but less than $0.05 \mathrm{DDD} / 1000$ males/day. In women, a remarkable rise can be seen in all age groups from 2007 to 2011. The trade of denosumab in females peaked in the 70-74-year-old population (0.37 DDD/1000females/day) in 2011. There was no denosumab use among male patients. 
Table 3 Gender- and age-standardised results

\begin{tabular}{|c|c|c|c|c|c|c|c|c|c|c|c|}
\hline & & $\begin{array}{l}40-44 \\
\text { years }\end{array}$ & $\begin{array}{l}45-49 \\
\text { years }\end{array}$ & $\begin{array}{l}50-54 \\
\text { years }\end{array}$ & $\begin{array}{l}55-59 \\
\text { years }\end{array}$ & $\begin{array}{l}60-64 \\
\text { years }\end{array}$ & $\begin{array}{l}65-69 \\
\text { years }\end{array}$ & $\begin{array}{l}70-74 \\
\text { years }\end{array}$ & $\begin{array}{l}75-79 \\
\text { years }\end{array}$ & $\begin{array}{l}80-84 \\
\text { years }\end{array}$ & $\begin{array}{l}85 \text { and } \\
\text { over }\end{array}$ \\
\hline \multicolumn{12}{|l|}{$\begin{array}{l}\text { Females } \\
\text { (DDD/1000females/day) }\end{array}$} \\
\hline Bisphosphonates & 2007 & 0.10 & 1.40 & 8.18 & 18.82 & 30.77 & 43.36 & 49.93 & 48.26 & 36.18 & 15.33 \\
\hline \multirow[t]{5}{*}{ М05BA, М05BВ } & 2008 & 0.05 & 1.22 & 8.05 & 18.72 & 31.37 & 44.92 & 52.58 & 53.38 & 39.94 & 17.02 \\
\hline & 2009 & 0.06 & 1.07 & 8.31 & 18.92 & 31.36 & 44.89 & 53.15 & 54.92 & 43.25 & 19.39 \\
\hline & 2010 & 0.05 & 0.72 & 7.17 & 17.79 & 28.54 & 41.14 & 49.72 & 53.24 & 42.93 & 19.44 \\
\hline & 2011 & 0.04 & 0.53 & 5.56 & 15.78 & 25.67 & 36.58 & 44.79 & 49.27 & 41.04 & 18.62 \\
\hline & $\begin{array}{l}\text { \% change } \\
2007-2011\end{array}$ & $-59.6 \%$ & $-62.0 \%$ & $-32.1 \%$ & $-16.1 \%$ & $-16.6 \%$ & $-15.6 \%$ & $-10.3 \%$ & $2.1 \%$ & $13.4 \%$ & $21.4 \%$ \\
\hline \multirow{6}{*}{$\begin{array}{l}\text { Strontium ranelate } \\
\text { М05BХ03 }\end{array}$} & 2007 & - & 0.01 & 0.12 & 0.40 & 0.66 & 1.06 & 1.42 & 1.44 & 1.22 & 0.45 \\
\hline & 2008 & - & 0.05 & 0.32 & 0.81 & 1.36 & 2.09 & 2.53 & 2.68 & 2.22 & 0.98 \\
\hline & 2009 & - & 0.07 & 0.54 & 1.39 & 2.32 & 3.58 & 4.20 & 4.32 & 3.65 & 1.76 \\
\hline & 2010 & - & 0.05 & 0.55 & 1.55 & 2.74 & 4.09 & 4.92 & 5.19 & 4.48 & 2.04 \\
\hline & 2011 & - & 0.04 & 0.52 & 1.64 & 2.95 & 4.31 & 5.33 & 5.85 & 5.20 & 2.72 \\
\hline & $\begin{array}{l}\% \text { change } \\
2007-2011\end{array}$ & - & $523.6 \%$ & $333.1 \%$ & $307.8 \%$ & $346.3 \%$ & $306.8 \%$ & $274.9 \%$ & $306.5 \%$ & $327.1 \%$ & $505.1 \%$ \\
\hline $\begin{array}{l}\text { Denosumab } \\
\text { M05BX04 } \\
\end{array}$ & 2011 & - & - & 0.08 & 0.12 & 0.23 & 0.24 & 0.37 & 0.30 & 0.12 & - \\
\hline \multicolumn{12}{|l|}{$\begin{array}{l}\text { Males } \\
\text { (DDD/1000males/day) }\end{array}$} \\
\hline Bisphosphonates & 2007 & 0.01 & 0.09 & 0.67 & 1.25 & 1.96 & 2.87 & 3.56 & 4.20 & 3.20 & 1.50 \\
\hline \multirow[t]{5}{*}{ М05ВА, М05ВВ } & 2008 & - & 0.12 & 0.67 & 1.29 & 2.03 & 3.10 & 3.75 & 4.51 & 3.73 & 1.53 \\
\hline & 2009 & 0.01 & 0.05 & 0.56 & 1.33 & 2.26 & 3.27 & 4.01 & 4.79 & 3.61 & 1.63 \\
\hline & 2010 & - & 0.06 & 0.36 & 1.12 & 1.78 & 2.95 & 3.45 & 3.88 & 3.58 & 1.71 \\
\hline & 2011 & - & 0.01 & 0.16 & 0.80 & 1.44 & 2.30 & 2.96 & 3.40 & 3.43 & 1.56 \\
\hline & $\begin{array}{l}\text { \% change } \\
2007-2011\end{array}$ & - & $-85.5 \%$ & $-76.7 \%$ & $-35.7 \%$ & $-26.6 \%$ & $-19.7 \%$ & $-16.8 \%$ & $-19.0 \%$ & $7.1 \%$ & $4.2 \%$ \\
\hline & & 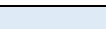 & & & & 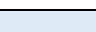 & 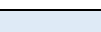 & & 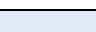 & & \\
\hline Strontium ranelate & 2007 & - & - & - & 一 & 一 & - & 0.01 & - & - & 一 \\
\hline \multirow[t]{5}{*}{ M05BX03 } & 2008 & - & - & - & - & - & 0.02 & 0.03 & 0.01 & 0.03 & 一 \\
\hline & 2009 & - & - & - & - & - & 0.02 & 0.04 & 0.04 & 0.02 & 一 \\
\hline & 2010 & - & - & - & - & 0.01 & 0.03 & 0.02 & 0.05 & - & 0.04 \\
\hline & 2011 & - & - & - & - & 0.01 & 0.02 & 0.03 & 0.01 & 0.05 & 0.03 \\
\hline & $\begin{array}{l}\% \text { change } \\
\text { first trade } \\
\text { year - } 2011\end{array}$ & - & - & - & - & - & $5.5 \%$ & $122.4 \%$ & $-29.1 \%$ & $68.2 \%$ & $-21.6 \%$ \\
\hline $\begin{array}{l}\text { Denosumab } \\
\text { M05BX04 }\end{array}$ & 2007-2011 & - & - & - & - & - & - & - & - & - & - \\
\hline
\end{tabular}




\subsubsection{Comparison with European countries}

Comparable DDD/TID values of anti-osteoporotic medication use were available from 2008 in Estonia, from 2009 in Finland, from 2010 in Latvia and Lithuania, and from 2007 in Norway; however, published age- and gender-matched data have not been found for the same time period [42-47]. The comparison is presented in Table 4.

Results on total bisphosphonate use differ in all investigated countries. The declining tendency and the utilisation rate were similar in Finland, in Norway, and in Hungary. In contrast, Estonian, Latvian and Lithuanian bisphosphonate use was about 2-3 times lower, but a slowly increasing tendency or constant rate (Lithuania) was present in all three Baltic countries. In Finland and in Hungary, alendronic acid monotherapy took the majority of the bisphosphonate trade, similarly to Norway, while in the Baltic countries the use of bisphosphonate agents was more various. Regarding bisphosphonate combinations, the use of alendronic acid and vitamin D combination was more or less constant in Latvia, Lithuania and in Hungary. In Finland, a certain decline was seen between 2009 and 2011, while the Estonian data on alendronic acid combination markedly increased, from 0.93 DDD/TID in 2008 to 2.52 DDD/TID in 2011. No use of bisphosphonate combinations was noticed in Norway. Strontium ranelate consumption was the highest in Hungary in 2010 and in 2011, similarly high in Lithuania, with an approximately 5-10-fold difference between Estonia, but the tendency of use was increasing in all countries, except in Norway (strontium ranelate is not available). Denosumab utilisation was the highest in Finland in 2011 (0.37 DDD/TID). 
Table 4 Gender- and age-standardised utilisation of specific anti-osteoporotic drugs between 2007 and 2011 in different countries

\begin{tabular}{|c|c|c|c|c|c|c|c|c|c|c|c|c|c|}
\hline DDD/TID & Drug & Bis. total & $\begin{array}{c}\text { Bis. mono- } \\
\text { therapy }\end{array}$ & $\begin{array}{c}\text { Bis. } \\
\text { combi- } \\
\text { nations }\end{array}$ & $\begin{array}{l}\text { Alendronic } \\
\text { acid }\end{array}$ & $\begin{array}{l}\text { Ibandronic } \\
\text { acid }\end{array}$ & $\begin{array}{l}\text { Risedronic } \\
\text { acid }\end{array}$ & $\begin{array}{l}\text { Zoledronic } \\
\text { acid }\end{array}$ & $\begin{array}{c}\text { Alendronic } \\
\text { acid + } \\
\text { Vitamin D }\end{array}$ & $\begin{array}{c}\text { Risedronic } \\
\text { acid + } \\
\text { Vitamin D } \\
\text { + Calcium }\end{array}$ & $\begin{array}{c}\text { Alendronic } \\
\text { acid + } \\
\text { Vitamin D } \\
\text { + Calcium }\end{array}$ & $\begin{array}{l}\text { Strontium } \\
\text { ranelate }\end{array}$ & $\begin{array}{c}\text { Denosu- } \\
\text { mab }\end{array}$ \\
\hline Country & $\begin{array}{l}\text { ATC/ } \\
\text { Years }\end{array}$ & $\begin{array}{c}\text { M05BA+ } \\
\text { M05BB }\end{array}$ & M05BA & M05BB & M05BA04 & M05BA06 & M05BA07 & M05BA08 & M05BB03 & M05BB04 & M05BB05 & M05BX03 & M05BX04 \\
\hline \multirow[t]{4}{*}{ Estonia } & 2008 & 3.34 & 2.41 & 0.93 & 1.17 & 0.79 & 0.44 & - & 0.9 & - & - & 0.04 & - \\
\hline & 2009 & 3.86 & 2.09 & 1.77 & 0.78 & 0.86 & 0.44 & - & 1.77 & - & - & 0.04 & - \\
\hline & 2010 & 4.52 & 2.10 & 2.42 & 0.65 & 0.93 & 0.52 & - & 2.42 & - & - & 0.06 & - \\
\hline & 2011 & 4.38 & 1.86 & 2.52 & 0.56 & 0.80 & 0.49 & - & 2.52 & - & - & 0.09 & 0.01 \\
\hline \multirow[t]{2}{*}{ Latvia } & 2010 & 3.74 & 2.55 & 1.19 & $<0.01$ & 0.96 & 1.59 & - & 1.19 & - & - & 0.42 & $<0.01$ \\
\hline & 2011 & 4.75 & 2.93 & 1.82 & 0.01 & 0.92 & 2.00 & - & 1.82 & - & - & 0.47 & 0.02 \\
\hline \multirow[t]{2}{*}{ Lithuania } & 2010 & 2.75 & 1.81 & 0.94 & 0.40 & 0.73 & 0.68 & - & 0.48 & 0.46 & - & 0.64 & $<0.01$ \\
\hline & 2011 & 2.66 & 1.71 & 0.95 & 0.37 & 0.73 & 0.61 & - & 0.45 & 0.50 & - & 0.53 & 0.07 \\
\hline \multirow[t]{3}{*}{ Finland } & 2009 & 10.80 & 8.34 & 2.46 & 3.84 & 1.95 & 2.54 & 0.01 & 2.46 & - & - & 0.07 & - \\
\hline & 2010 & 8.89 & 7.02 & 1.87 & 3.08 & 1.83 & 2.10 & 0.01 & 1.87 & - & - & 0.14 & 0.02 \\
\hline & 2011 & 7.97 & 6.52 & 1.45 & 2.97 & 1.73 & 1.81 & 0.01 & 1.45 & - & - & 0.32 & 0.37 \\
\hline \multirow[t]{5}{*}{ Norway } & 2007 & 9.32 & 9.32 & - & 8.86 & 0.19 & 0.27 & $<0.01$ & - & - & - & - & - \\
\hline & 2008 & 9.32 & 9.32 & - & 8.94 & 0.16 & 0.22 & $<0.01$ & - & - & - & - & - \\
\hline & 2009 & 9.05 & 9.05 & - & 8.71 & 0.15 & 0.19 & $<0.01$ & - & - & - & - & - \\
\hline & 2010 & 9.00 & 9.00 & - & 8.71 & 0.12 & 0.17 & $<0.01$ & - & - & - & - & $<0.01$ \\
\hline & 2011 & 8.81 & 8.81 & - & 8.56 & 0.10 & 0.15 & $<0.01$ & - & - & - & - & 0.07 \\
\hline \multirow[t]{5}{*}{ Hungary } & 2007 & 6.66 & 5.07 & 1.60 & 3.91 & 0.68 & 0.48 & - & 0.91 & 0.69 & 0.10 & 0.16 & - \\
\hline & 2008 & 7.04 & 4.24 & 2.80 & 3.30 & 0.79 & 0.14 & $<0.01$ & 1.42 & 1.27 & 0.11 & 0.32 & - \\
\hline & 2009 & 7.27 & 3.88 & 3.39 & 2.75 & 0.99 & 0.14 & $<0.01$ & 2.02 & 1.23 & 0.14 & 0.54 & - \\
\hline & 2010 & 6.85 & 3.58 & 3.28 & 2.25 & 1.12 & 0.21 & $<0.01$ & 2.08 & 1.05 & 0.15 & 0.64 & - \\
\hline & 2011 & 6.22 & 3.42 & 2.81 & 1.94 & 1.11 & 0.37 & $<0.01$ & 1.90 & 0.77 & 0.14 & 0.70 & 0.04 \\
\hline
\end{tabular}




\subsubsection{Incidence of hip fractures}

Investigating the Hungarian incidence of hip fractures in 2007 and 2011 would probably provide a better understanding of the importance of osteoporosis treatment. According to the "Tables of basic data on Hungarian health care", the highest incidence of osteoporotic hip fractures was 3332.8 per 100,000 females aged 85 above, and 2151.2 per 100,000 males for the same age group in 2011 [52]. An exponentially growing tendency with age can be seen in the incidence of osteoporotic hip fractures in both investigated years (Figure 6). The incidence between 2007 and 2011 was more or less constant, showing slightly elevating tendency above the age of 75 years in both genders. However, a remarkable $8.7 \%$ increase in absolute number of hip fractures could be seen (17,432 hip fractures in 2007 and 19,093 in 2011), owing probably to the increasing number of elderly people in the Hungarian society.

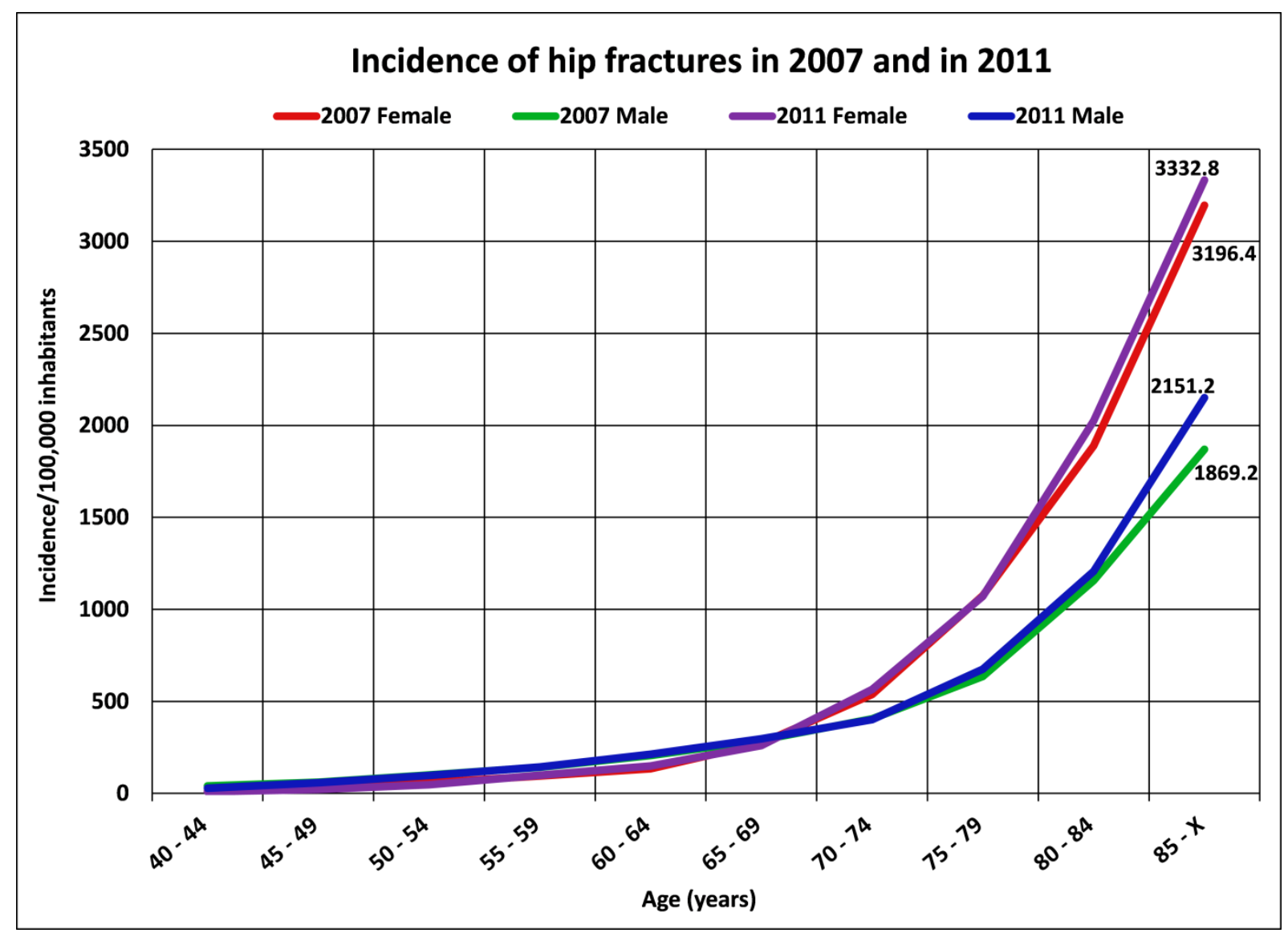

Figure 6 Incidence of hip fractures in 2007 and 2011 in Hungary 


\subsection{Medication use and fall prevalence among nursing home residents}

\subsubsection{Demography}

A total of 197 nursing home residents were included in the study, 150 (76.2\%) women and $47(23.8 \%)$ men (Table 5). Among the 55 fallers 44 were females and 11 were males, therefore the annual fall prevalence rate was $27.9 \%$. Out of the 142 non-faller residents, 106 were females and 36 were males. The gender was not found to be a predisposing factor for falls (prevalence in males: $23.4 \%$ versus $29.3 \%$ in females, $p>0.05$ ). Bone fractures occurred in 24 patients ( 5 males and 19 females, $43.6 \%$ of fallers).

Regarding age, fallers were older ( 84.0 years \pm 7.0 years) than non-fallers $(80.1$ years \pm 9.3 years, $\mathrm{p}<0.01)$. The age above or equal to 80 years was found to be a significant risk factor for falls $(\mathrm{p}<0.001)$. Among fallers, 47 residents $(85.5 \%)$ were 80 years old or older, and all the 13 multiple fallers (more than 1 fall per year) were in this group.

Table 5 Study population characteristics. ${ }^{*}$ Chi-squared test was applied for categorical variables, Student's t-test for continuous variables, and Fisher's test in case of polypharmacy. (Polypharmacy: concomitant use of minimum 4 or more chronic medications; PIM: Potentially inappropriate medication use; PIM fall risk: PIMs carrying risk of falls)

\begin{tabular}{|c|c|c|c|c|c|}
\hline & & Fallers & Non-fallers & n-yoluo* & Total \\
\hline & & $(55 ; 27.9 \%)$ & $(142 ; 72.1 \%)$ & p-value & $(197 ; 100.0 \%)$ \\
\hline Gender & females (\% of all females) & $44(29.3 \%)$ & $106(70.7 \%)$ & $=0407$ & $150(76.2 \%)$ \\
\hline & males ( $\%$ of all males) & $11(23.4 \%)$ & $36(76.6 \%)$ & $\mathrm{p}=0.421$ & $47(23.8 \%)$ \\
\hline Age (years) & mean $\pm \mathrm{SD}$ & $84.0 \pm 7.0$ & $80.1 \pm 9.3$ & $p=0.002$ & $81.2 \pm 8.9$ \\
\hline & $\min -\max$ & $61-99$ & $52-104$ & - & $52-104$ \\
\hline Age group 80 y & ears or older (\% of group) & $47(35.9 \%)$ & $84(64.1 \%)$ & 00001 & $131(66.5 \%)$ \\
\hline Age group less & than 80 years (\% of group) & $8(12.1 \%)$ & $58(87.9 \%)$ & & $66(33.5 \%)$ \\
\hline Number of & mean $\pm \mathrm{SD}$ & $9.1 \pm 3.8$ & $8.0 \pm 3.9$ & $\mathrm{p}=0.093$ & $8.32 \pm 3.88$ \\
\hline chronic & $\min -\max$ & $3-19$ & $0-18$ & - & $0-19$ \\
\hline & males $($ mean $\pm \mathrm{SD})$ & $12.4 \pm 4.0$ & $6.9 \pm 4.2$ & $\mathbf{p}<0.001$ & $8.2 \pm 4.7$ \\
\hline & females (mean $\pm \mathrm{SD})$ & $8.3 \pm 3.3$ & $8.4 \pm 3.7$ & $\mathrm{p}=0.810$ & $8.4 \pm 3.6$ \\
\hline Polypharmacy & yes (\% of group) & $54(98.2 \%)$ & $122(85.9 \%)$ & 0010 & $176(89.3 \%)$ \\
\hline & no (\% of group) & $1(1.8 \%)$ & $20(14.1 \%)$ & 0.010 & $21(10.7 \%)$ \\
\hline PIM & yes (\% of group) & $40(72.7 \%)$ & $112(78.9 \%)$ & & $152(77.2 \%)$ \\
\hline & no (\% of group) & $15(27.3 \%)$ & $30(21.1 \%)$ & & $45(22.8 \%)$ \\
\hline PIM fall risk & yes ( $\%$ of group) & $39(70.9 \%)$ & $107(75.3 \%)$ & & $146(74.1 \%)$ \\
\hline & no (\% of group) & $16(29.1 \%)$ & $35(24.6 \%)$ & & $51(25.9 \%)$ \\
\hline
\end{tabular}




\subsubsection{Medication patterns}

The number of chronic medications taken did not significantly differ between fallers and non-fallers $(9.1 \pm 3.8$ vs. $8.0 \pm 3.9, \mathrm{p}>0.05)$ (Table 5), but did differ among male fallers and male non-fallers $(12.4 \pm 4.0$ vs. $6.9 \pm 4.2, \mathrm{p}<0.001)$. Also, polypharmacy (taking 4 or more chronic medications) was a significant risk factor of falls $(\mathrm{p}=0.01)$. Polypharmacy occurred in $85.9 \%$ among non-faller patients, but in $98.2 \%$ among fallers $(\mathrm{p}=0.01)$.

\subsubsection{Potentially inappropriate medications}

Regarding the prevalence of PIM medication use, $77.2 \%$ of the residents took one or more PIM-list positive drug, and there was no significance in prevalence between fallers and non-fallers $(72.7 \%$ vs. $78.9 \%$, p>0.05). Those PIMs carrying risk of falls were taken by $70.9 \%$ of fallers and $75.3 \%$ of non-fallers ( $>>0.05$ ). PIM use was illustrated on the so called Venn diagram (Figure 7A and Figure 7B). To provide better understanding, we considered implementing the age dimension into this visualisation.

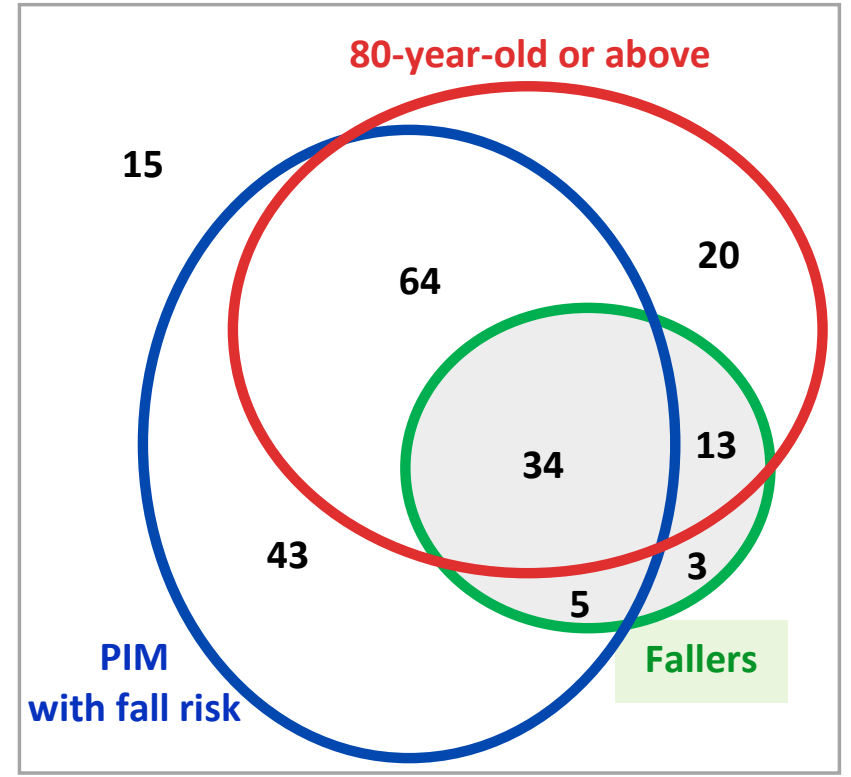

Figure 7A Venn diagram illustrates the populations (sets) that were subject to multiple drug use: residents taking potentially inappropriate medications (PIM) with fall risk; fallers; patients who were 80 years old or older, and those who were not part of any of these three sets.

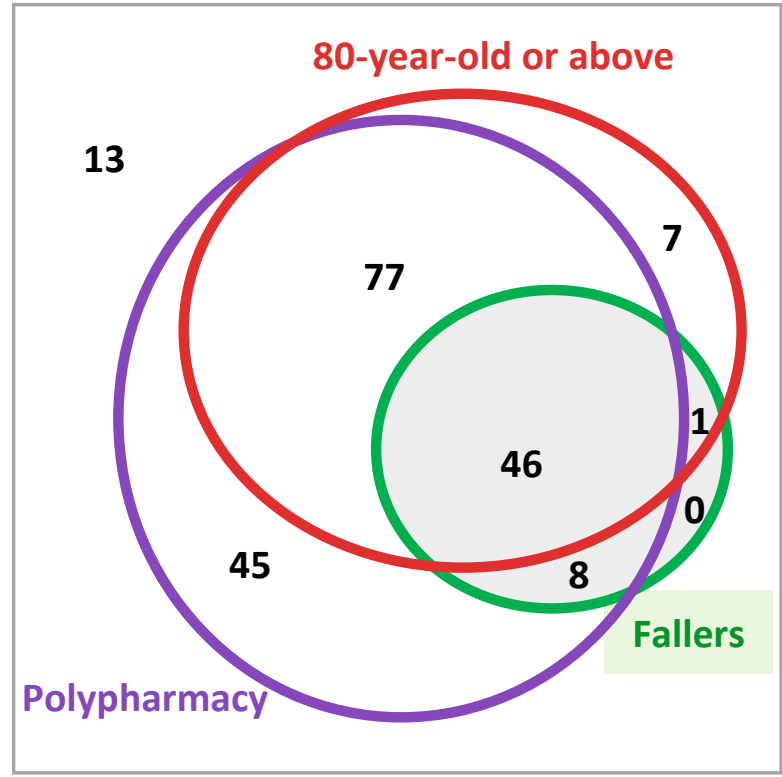

Figure 7B Venn diagram illustrates the populations (sets) that were subject to multiple drug use: those residents taking 4 or more chronic drugs (Polypharmacy); fallers; patients who were 80 years old or older, and those who were not part of any of these three sets. 
Except for 2 non-medicated residents, 195 were taking 227 different drugs, out of which 22 drugs were taken by at least $10 \%$ of the patients (minimum 20 individuals). For the most prevalent drugs, positive predictive values (with 95\% confidence intervals) were calculated to estimate the impact of each medication on fall risk (Table 6). Considering the $27.9 \%$ annual fall prevalence rate in the nursing home, the lower confidence interval exceeded this margin in case of trimetazidine (PPV (95\% CI) 0.48 (0.30-0.66), vinpocetine $0.44(0.31-0.59)$ and pantoprazole $0.40(0.30-0.52)$. Hence, those drugs seem to be significant risk factors for falls (Figure 8).

Table 6 Positive predictive values (PPV) of drugs (with 95\% CI: confidence intervals). Displayed drugs were taken by minimum 20 individuals (10\% of all residents).

\begin{tabular}{lccc}
\hline \multicolumn{1}{c}{ Active substance } & No. of takers $(\boldsymbol{\%})$ & No. of fallers & PPV (95\% CI) \\
\hline trimetazidine & $\mathbf{2 3}(\mathbf{1 1 . 6 8 \%})$ & $\mathbf{1 1}$ & $\mathbf{0 . 4 8}(\mathbf{0 . 3 0 - 0 . 6 6 )}$ \\
\hline isosorbide mononitrate & $20(10.15 \%)$ & 9 & $0.45(0.26-0.65)$ \\
vinpocetine & $\mathbf{3 6}(\mathbf{1 8 . 2 7 \%})$ & $\mathbf{1 6}$ & $\mathbf{0 . 4 4}(\mathbf{0 . 3 1 - 0 . 5 9 )}$ \\
\hline tiapride & $28(14.21 \%)$ & 12 & $0.43(0.27-0.60)$ \\
atorvastatin & $29(14.72 \%)$ & 12 & $0.41(0.27-0.58)$ \\
pantoprazole & $\mathbf{5 2}(\mathbf{2 6 . 4 \% )}$ & $\mathbf{2 1}$ & $\mathbf{0 . 4 0}(\mathbf{0 . 3 0 - 0 . 5 2})$ \\
allopurinol & $21(10.66 \%)$ & 8 & $0.38(0.21-0.58)$ \\
glyceryl trinitrate & $36(18.27 \%)$ & 13 & $0.36(0.24-0.51)$ \\
famotidine & $33(16.75 \%)$ & 11 & $0.33(0.21-0.49)$ \\
levothyroxine sodium & $30(15.23 \%)$ & 10 & $0.33(0.20-0.50)$ \\
\hline acetylsalicylic acid & $74(37.56 \%)$ & 24 & $0.32(0.25-0.41)$ \\
\hline alprazolam & $63(31.98 \%)$ & 20 & $0.32(0.23-0.42)$ \\
bisoprolol & $33(16.75 \%)$ & 10 & $0.30(0.18-0.46)$ \\
amlodipine & $42(21.32 \%)$ & 12 & $0.29(0.18-0.42)$ \\
\hline pentoxifylline & $29(14.72 \%)$ & 8 & $0.28(0.15-0.45)$ \\
metoprolol & $43(21.83 \%)$ & 10 & $0.23(0.14-0.36)$ \\
\hline furosemide & $65(32.99 \%)$ & 15 & $0.23(0.16-0.33)$ \\
\hline potassium chloride & $68(34.52 \%)$ & 15 & $0.22(0.15-0.31)$ \\
perindopril and amlodipine & $28(14.21 \%)$ & 6 & $0.21(0.10-0.39)$ \\
acenocoumarol & $20(10.15 \%)$ & 4 & $0.20(0.08-0.42)$ \\
piracetam & $40(20.3 \%)$ & 7 & $0.18(0.09-0.31)$ \\
metformin & $22(11.17 \%)$ & 3 & $0.14(0.05-0.34)$ \\
\hline
\end{tabular}

Giving an example for better understanding, the 0.40 PPV of pantoprazole shows the proportion of patients who used pantoprazole and who had fall(s). This means that taking the drug increases the fall prevalence rate by approximately $12 \%$ (compared to the annual $27.9 \%$ fall prevalence rate). 


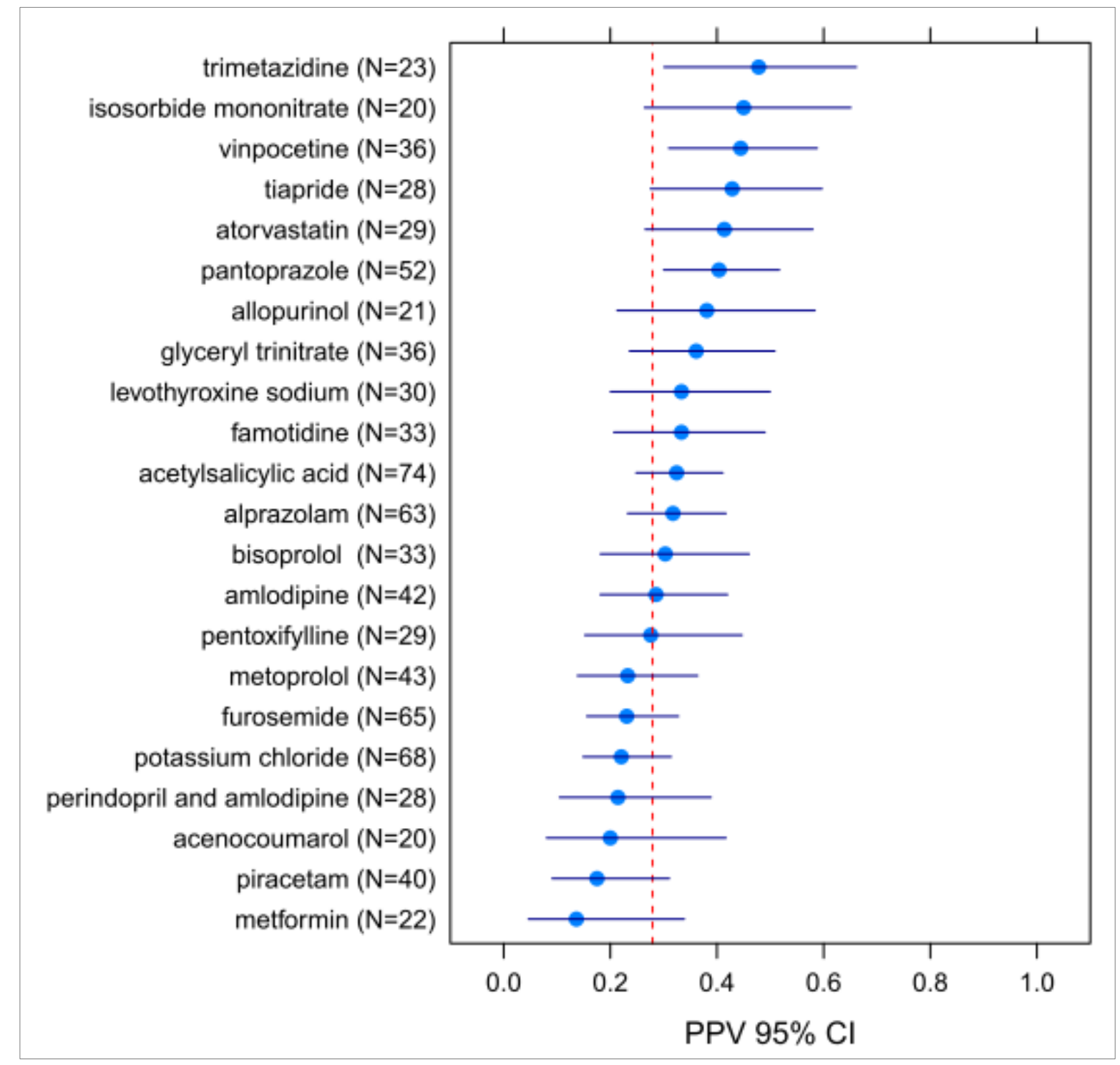

Figure 8 Positive predictive values (PPV) of drugs (with 95\% confidence intervals, CI 95\%, $\mathrm{N}=$ number of drug users). Dashed red line shows the annual fall prevalence rate $(27.9 \%)$ in the nursing home. Displayed drugs were taken by minimum $10 \%$ of all residents.

For the same drugs, the number needed to harm $(\mathrm{NNH}, 95 \% \mathrm{CI})$ was calculated (groups were the following: particular drug user or non-user, and the outcome/risk was falls). Accordingly, approximately 4-5 patients are needed to be exposed to trimetazidine and vinpocetine use to sustain a fall, while this number is about 6 in the case of pantoprazole exposure (Table 7).

Table 7 Number needed to harm (NNH) values (with 95\% CI: confidence intervals) of trimetazidine, vinpocetine and pantoprazole ( $\mathrm{N}$ : number of takers).

\begin{tabular}{|l|c|c|}
\hline \multicolumn{1}{|c|}{ Drugs (number of drug users) } & NNH & $\mathbf{9 5} \% \mathbf{C I}$ \\
\hline trimetazidine $(\mathbf{N}=\mathbf{2 3})$ & 4.5 & $2.3-55.1$ \\
\hline vinpocetine $(\mathbf{N}=\mathbf{3 6})$ & 5.0 & $2.7-32.6$ \\
\hline pantoprazole $(\mathbf{N}=\mathbf{5 2})$ & 5.9 & $3.2-47.0$ \\
\hline
\end{tabular}


These numbers are clinically remarkable. We would like to emphasize that the NNH values calculated above cannot be extended for the entire population of old people; they are valid only for the involved nursing home residents.

The variables of the binary logistic regression model were the following: age group 80 years and above, persons taking pantoprazole, vinpocetine or trimetazidine. The binary logistic regression confirmed the significant impact of the 80+ age group, pantoprazole, and vinpocetine on fall risk, odd ratios were respectively 3.92, 2.59 and 2.32, with $73.6 \%$ accuracy detected (Table 8).

Table 8 Results of binary logistic regression analysis (CI: confidence interval; OR: odds ratio).

\begin{tabular}{|l|c|c|}
\hline \multicolumn{1}{|c|}{ Variables } & Coefficients $(\mathbf{p}$-value $)$ & OR $(\mathbf{9 5 \%}$ CI) \\
\hline age group 80 years old or above & $1.3660(\mathrm{p}=0.00175)$ & $3.92(1.67-9.22)$ \\
\hline pantoprazole & $0.9498(\mathrm{p}=0.01049)$ & $2.59(1.25-5.35)$ \\
\hline vinpocetine & $0.8411(\mathrm{p}=0.03760)$ & $2.32(1.05-5.12)$ \\
\hline trimetazidine & $0.7181(\mathrm{p}=0.13296)$ & $2.05(0.80-5.23)$ \\
\hline
\end{tabular}

\subsubsection{Prevention and treatment of osteoporosis}

We analysed the prevalence of anti-osteoporotic drugs among the nursing home residents. Out of 197 subjects, 6 females have received oral bisphosphonate therapy, evenly distributed between the ages of 64 and 95 years. All the six females received calcium and vitamin D supplementation as well. Furthermore, 20 individuals took vitamin D (only 3 male patients), and 7 subjects received calcium monotherapy (only 1 male patient). 


\subsection{Vitamin D levels of elderly hospitalised patients}

\subsubsection{Demography}

Twenty-two patients were in the fractured group (mean age 84.1 years, $\mathrm{SD} \pm 6.8$ ) and 33 patients were in the control group (mean age 80.5 years, $\mathrm{SD} \pm 6.6$ ); the majority of patients were women in both groups (Table 9). Therefore the investigated groups did not differ significantly in demographic pattern, as stated in the Methods section.

Table 9 Study population characteristics. (*Student's t-test.)

\begin{tabular}{|c|c|c|c|c|c|}
\hline & & $\begin{array}{c}\text { Patients with } \\
\text { hip fracture } \\
22 ; 40 \%\end{array}$ & $\begin{array}{c}\text { Patients with no } \\
\text { fracture (controls) } \\
33 ; 60 \%\end{array}$ & p- value* & $\begin{array}{c}\text { Total } \\
55 ; 100 \%\end{array}$ \\
\hline \multirow{2}{*}{ Gender } & females & $20 ; 91 \%$ & $29 ; 88 \%$ & \multirow[t]{2}{*}{-} & $49 ; 89 \%$ \\
\hline & males & $2 ; 9 \%$ & $4 ; 12 \%$ & & $6 ; 11 \%$ \\
\hline \multirow{2}{*}{ Age (years) } & mean $\pm \mathrm{SD}$ & $84.1 \pm 6.8$ & $80.5 \pm 6.6$ & \multirow{2}{*}{$p>0.05$} & $82.0 \pm 6.84$ \\
\hline & $\min -\max$ & $71-92$ & 71-98 & & $71-98$ \\
\hline \multirow{2}{*}{$\begin{array}{l}\text { Vitamin D } \\
\text { level (ng/ml) }\end{array}$} & mean $\pm \mathrm{SD}$ & $33.8 \pm 17.2$ & $39.7 \pm 21.3$ & \multirow{2}{*}{$\mathrm{p}>0.05$} & $37.4 \pm 19.8$ \\
\hline & $\min -\max$ & $12.8-74.4$ & $17.0-107.1$ & & $12.8-107.1$ \\
\hline
\end{tabular}

\subsubsection{Vitamin D level}

Serum vitamin D level was normal (sufficient; $>30 \mathrm{ng} / \mathrm{ml}$ ) in $66.7 \%$ of the controls, and in $45.4 \%$ of fractured patients. Vitamin D insufficiency $(20-30 \mathrm{ng} / \mathrm{ml})$ was higher in the fractured group (27.3\% vs. $21.2 \%)$, as well as the prevalence of deficiency $(<20 \mathrm{ng} / \mathrm{ml})$ $(27.3 \%$ vs. $12.1 \%)$, though we couldn't find any statistical significance between the groups (Figure 9A).

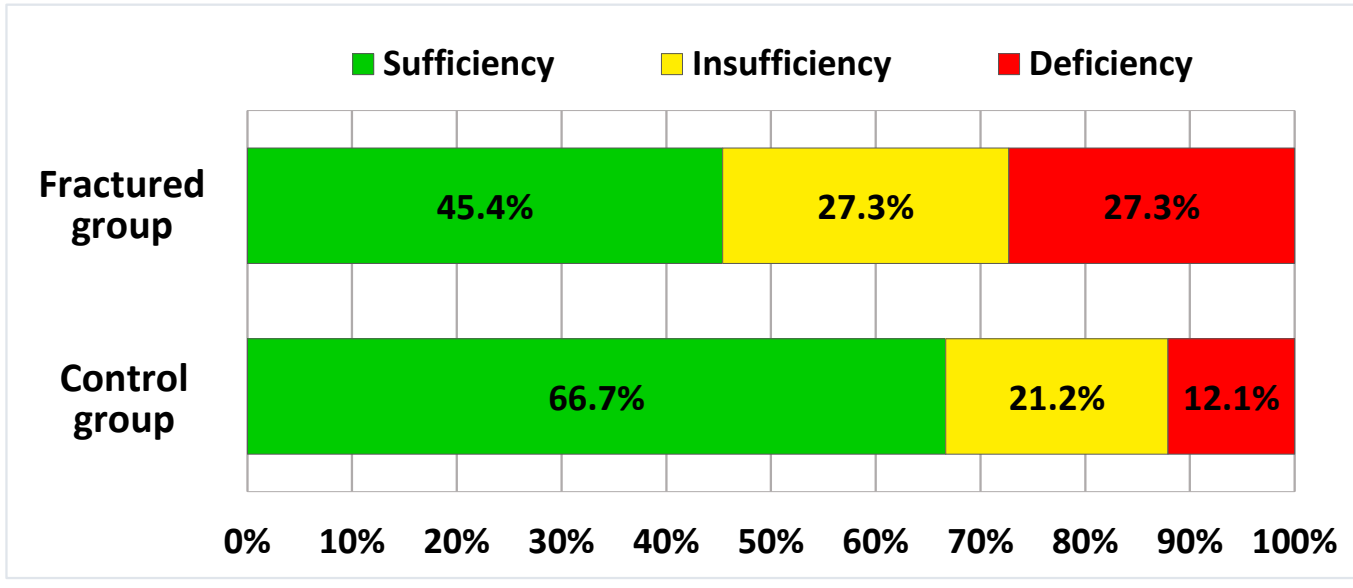

Figure 9A Proportion of vitamin D levels of fractured and control patients 
The mean vitamin D level was $33.8 \mathrm{ng} / \mathrm{ml}$ in the fractured group and $39.7 \mathrm{ng} / \mathrm{ml}$ in the control group ( $\mathrm{p}=0.230)$. Distribution of patients was similar in both groups (Figure 9B).
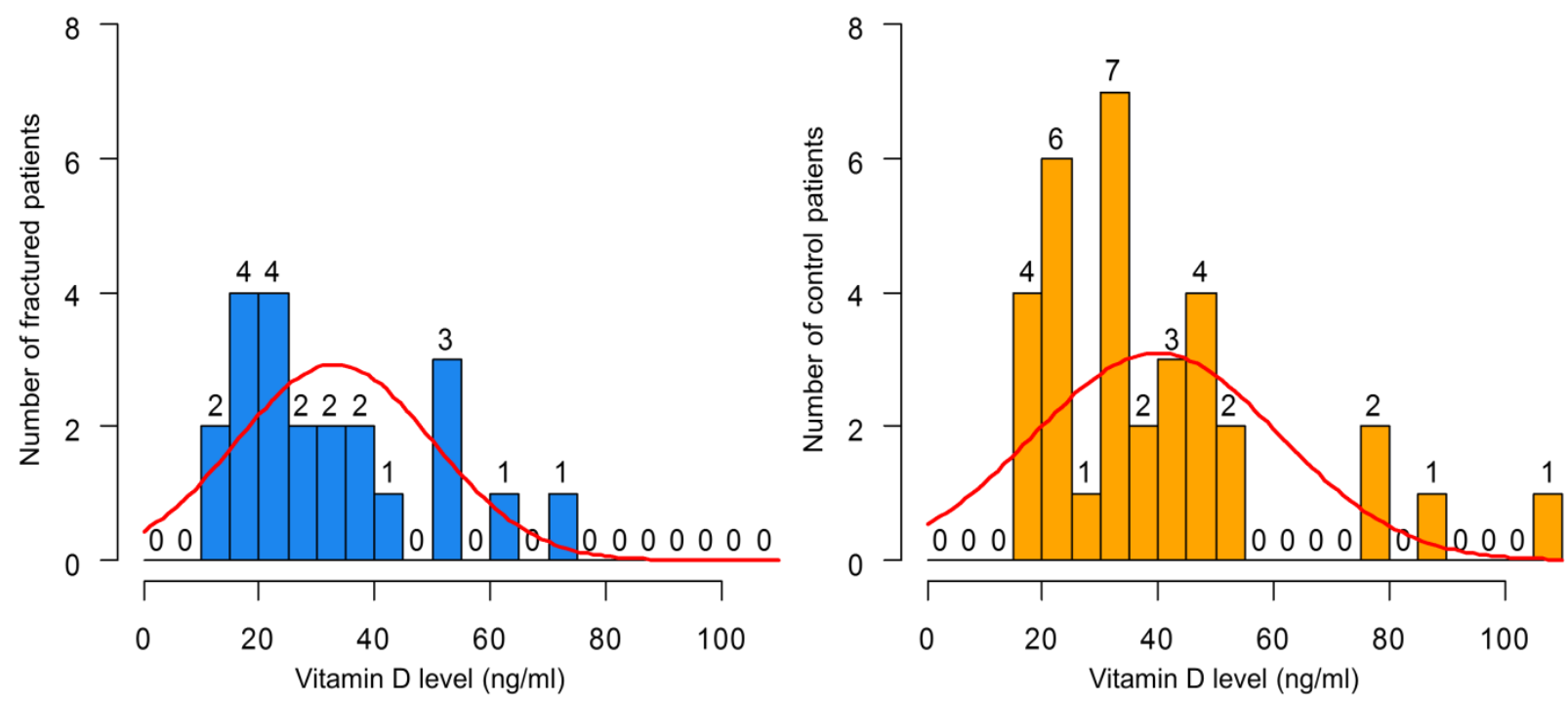

Figure 9B Distribution of fractured (blue) and control patients (yellow) by vitamin D levels

\subsubsection{Falls reported}

Patients in fractured group reported considerably more falls within one year than in the control group. An important finding may be that about $36.4 \%$ of fractured patients, and $30.3 \%$ of control patients reported more than 2 falls in the previous year (Figure 10).

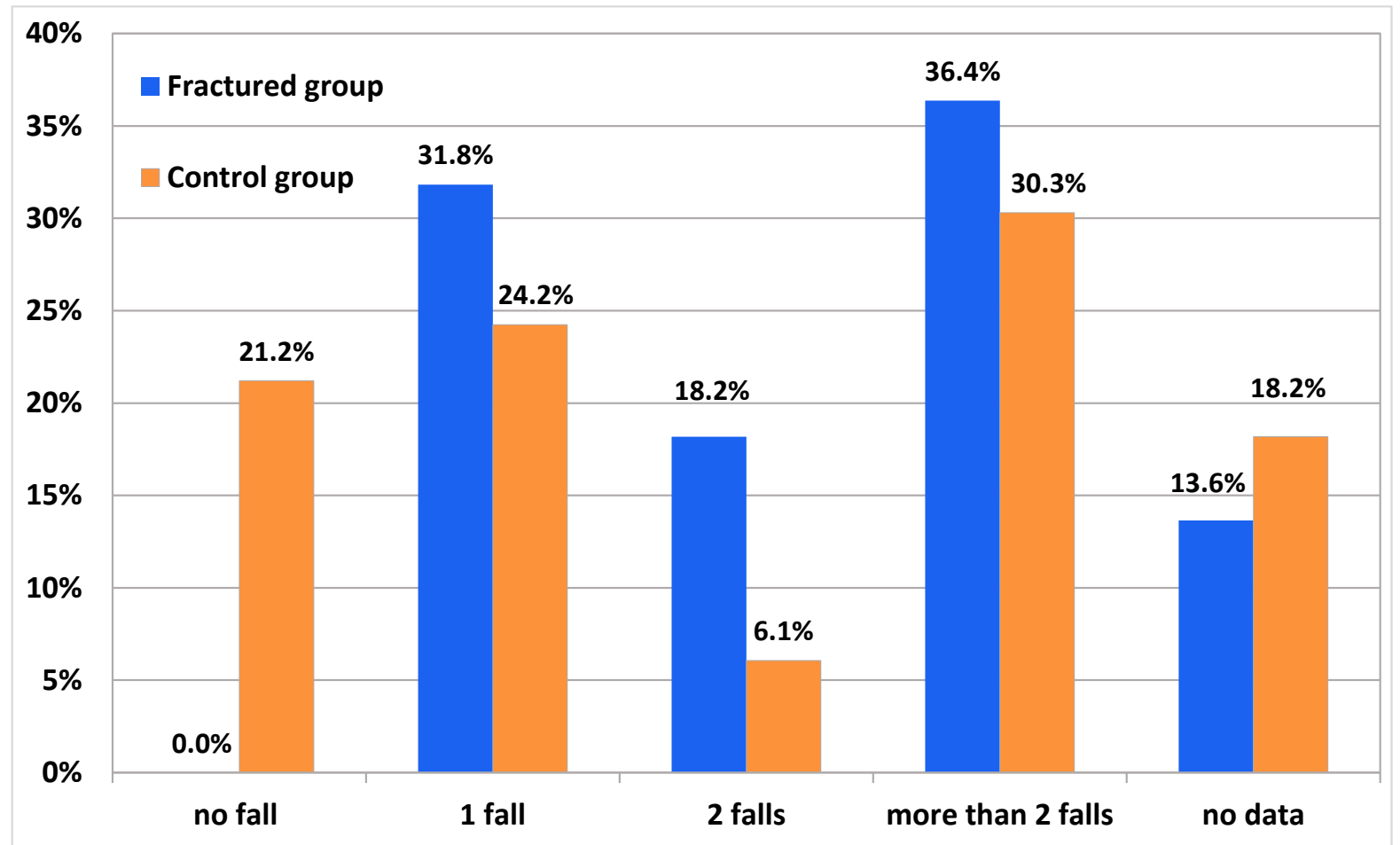

Figure 10 Prevalence of falls 


\section{DISCUSSION}

\subsection{Utilisation study of anti-osteoporotic drugs}

A retrospective gender- and age-specific drug utilisation analysis was performed of medications indicated for the treatment of osteoporosis between 2007 and 2011 in Hungary. As expected, men were disproportionately undertreated in all age groups compared to women, and treatment choice was restricted for vitamin D, calcium supplementation and bisphosphonates compared to women. The persistent 10-20-fold difference between males and females does not reflect the estimated 1:5 proportion of males and females affected by osteoporosis in Hungary. In a similar age and gender-standardised Australian study, a much milder 3-4-fold gender difference was found between the use of alendronic- and risedronic acid in 2005-2006 [64]. Recently, results of numerous randomised controlled trials have confirmed that anti-osteoporotic drugs are equally effective in males and females [65-68]. Based on those findings, the recommended treatment options for male patients are calcium and vitamin D supplementation as first line treatment, and in combination with alendronate, risedronate, zoledronate, denosumab and teriparatide. All of these drugs are available in Hungary, however, in practice, besides health professional considerations, drug choice is also determined by the costs and reimbursement criteria.

Among osteoporotic fractures, hip fractures are responsible for the greatest costs and high mortality rates, the male-female ratio is constant at about 30:70 [25, 28]. Based on international literature data, $25 \%$ of people with hip fracture die within 1 year, and the 5 -year survival is only $41 \%$, with an estimated 740,000 deaths worldwide [25, 69]. One year after hip fracture the mortality rate is almost double in men than in women: $26.8-32.5 \%$ versus $17-$ $21.9 \%$ [18, 23-32]. The rate of frailty and co-morbidities in men contribute to higher mortality rates and explains the high rate of long-term care and hospitalisation, as well as greater rates of smoking and alcohol abuse among men can worsen the outcome [65, 66]. Nevertheless, lifetime risk of osteoporotic fracture at age 50 is 20-25\% in Caucasian men (versus 45-55\% in women), which fact should not be neglected [70]. As the incidence of hip fractures showed an exponentially growing tendency with age in our study, adjusting the trend of antiosteoporotic medications to the population under the greatest risk would be considerable. Appropriate and proportional treatment of the $80+$ populations would be an important issue in both men and women. Also, in case of diagnosed osteoporosis, pharmacological fracture 
prevention may be initiated in the earliest ages as possible to reduce late-age incidence of hip fractures.

A constantly growing utilisation was seen in the case of vitamin D and calcium compounds in both genders during the investigated period. A possible reason could be the increasing number of articles on vitamin D and calcium supplementation in the past 10 years worldwide, which resulted in wider publicity and guideline implementations of these agents as first-line therapy, also in Hungary.

In contrast, bisphosphonate use showed a gradually declining tendency. The peak age of utilisation was 75-79 years in both genders, while in Australia the peak age was 80-89 years in females and 85-94 years in males [64]. This difference may be explained by the higher life expectancy rate at birth in Australia, which was 83 years in 2012, compared to 75 years in Hungary [71]. This age utilisation profile only partially corresponds to the population with the highest prevalence of osteoporotic fractures, as hip fractures are the highest in the 85+ populations in Hungary. A Swedish study also reported declining probability of bisphosphonate use with increasing age, especially in 85+ age groups [72].

Large differences were seen when comparing utilisation data of different countries. Unfortunately, a reliable explanation of these discrepancies or any similar comparison has not been found in the literature. The 2 or 3 fold differences in the utilisation rate can partially be explained with the different reimbursement policies of the investigated countries or difference in patient registration system. As an example, in Hungary, as a result of substantial cut in the reimbursement rate, the use of risedronic acid (monotherapy) dropped to one-third of its trade in 2008 compared to 2007, and it still has not reached the 2007 level in 2011.

The different screening methods and the applied diagnostic criteria can also influence the use of anti-osteoporotic drugs. In Finland and in Hungary - and in most European countries - DEXA (Dual-Energy X-Ray Absorptiometry) is the gold standard diagnostic tool for osteoporosis [73]. Yet, there is a debate on the reference values of DEXA, the International Osteoporosis Foundation recommends a sex-specific T-score, while the WHO recommends using the reference values of a 20 to 30-year-old white U.S. woman to define DEXA T-score (-2.5 T-score) [65]. In a Dutch study, using a T-score value $<-2.5$, only $21 \%$ of men and $44 \%$ of women were identified among those sustained non-vertebral fracture [74]. Hence, there is a great need to develop more sensitive fracture prediction tools, and implement them into the diagnostic criteria. Integrating several relevant clinical risk factors, 
FRAX is the most widely used fracture risk assessment tool for prediction of 10-year probability of a major osteoporotic (i.e. spine, forearm or shoulder) and hip fracture [75]. If available, femoral neck BMD value of the individual can be also typed in, therefore FRAX results can be further specified.

Furthermore, adequate patient compliance and persistence is a crucial determinant of successful pharmacological therapy of osteoporosis. Compliance is defined as taking drugs as directed (timing, dosage and frequency) and persistence as continuing the treatment for the prescribed duration [76]. A novel German study found 55.2\% non-compliance of more than 10,000 treated osteoporotic patients, who were followed for one year. Compliance increased with age and was better in patients with previous osteoporotic fracture(s). Non-compliance was higher in men versus women $(\mathrm{OR}=1.15)$ and patients receiving oral versus injectable therapy $(\mathrm{OR}=1.68)$. Daily and monthly therapies were associated with poorer compliance than weekly regimens; three-or six monthly injectable therapies showed the best results [21]. Similarly, in a recent Italian retrospective analysis, with 30,000 osteoporotic subjects, male gender carried $11 \%$ higher risk of discontinuation (persistence) compared to female gender $(\mathrm{HR}=0.89)$. Also, patients who started treatment with a co-administration of calcium and vitamin $\mathrm{D}$ had a lower risk of early discontinuation $(\mathrm{HR}=0.72)$. The best persistence at one year was reported in patients treated with monthly bisphosphonates $(21.6 \%)$ than subjects treated with daily bisphosphonates or strontium ranelate [77]. A recent Hungarian survey found only $24 \%$ and $39 \%$ compliance for daily and weekly oral osteoporosis therapy after 12 months of treatment initiation, while compliance rate was $64 \%$ and $70 \%$ for 3 -monthly and 6monthly parenteral therapy in post-menopausal women. Good compliance was associated with a statistically significant reduction in the risk of fracture, fracture-related hospitalisation and in risk of death [78]. A former British study reported that $58.3 \%$ of the patients continued bisphosphonate treatment for more than 1 year and $23.6 \%$ for more than 5 years. They also found positive correlation between weekly bisphosphonates therapy and compliance compared with patients using daily bisphosphonates [79]. Thus, males and patients on oral therapies (other than weekly regimen) should be prioritised in terms of improving compliance and persistence.

Bisphosphonates are pyrophosphate analogues that bind to the hydroxyapatite crystals in bone tissue and suppress osteoclast-mediated bone resorption by inducing the apoptosis of osteoclast [80]. Advantages and efficacy of these agents in the treatment of osteoporosis are proven and well-established. However, growing concern has been raised regarding the 
potential complications of prolonged bisphosphonates therapy, such as BRONJ (bisphosphonate-related osteonecrosis of the jaw) and atypical fractures. A systematic review article published wide incidence rates of BRONJ, ranging from $0.01 \%$ to $4.3 \%$ [81]. The Hungarian Dental Association estimates 0.1-0.2\% prevalence in Hungary, being higher in association with intravenous and anti-cancer therapy [82]. Despite BRONJ is a relatively rare condition, prevention and early recognition are primary, as treatment options are limited and the results are unsatisfying. Therefore national guidelines and literature suggest careful dental examination and appropriate management before the initiation of bisphosphonates therapy [80, 82, 83]. Atypical femoral fractures are also associated with long-term use of bisphosphonates, and described as 'unusual' low-energy fractures, with atypical radiographic appearance (Figure 11). They are located in the subtrochanteric region and diaphysis of the femur and are characterised by simple transverse, or short oblique fracture in areas of thickened cortices with a unicortical beaking [84-87]. The absolute risk varies between 3.2-100 cases per 100,000 person-years, strongly depending on the duration of bisphosphonate therapy $[84,85,88]$. Bone healing is often delayed or failed in approximately $30 \%$ of these patients $[87,89,90]$. Thus, in harmony with the FDA recommendations, interruption and evaluation of bisphosphonates therapy is suggested after 3 years of continuous administration. Additionally, the termination of treatment is considerable after 5 years, as there is no evidence of further efficacy over this period of time [83, 85, 91].

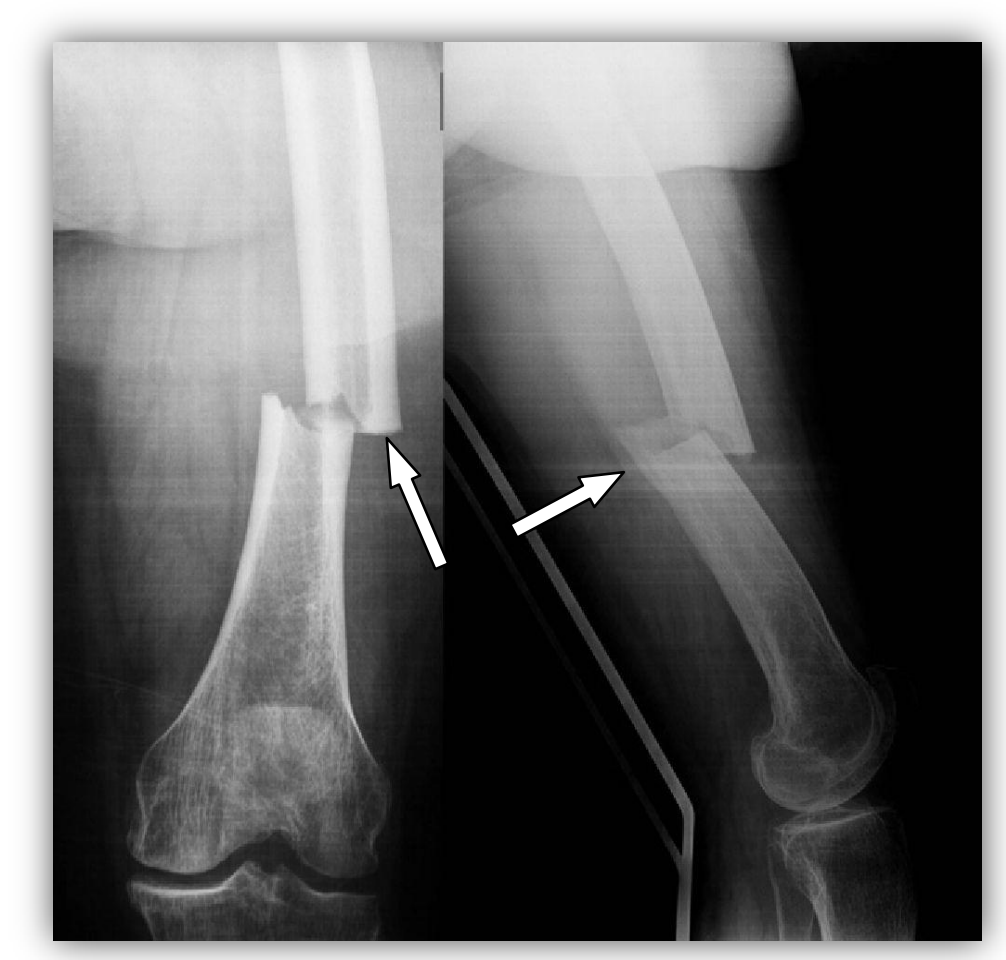

Figure 11 Radiographic picture of an atypical femur fracture. The arrows show the transversal fracture and thickened cortices with a unicortical beaking [90]. (Permission to use images granted by Ana Méndez.) 
The recent concerns about strontium ranelate (Protelos/Osseor) treatment must also be mentioned. Protelos/Osseor must not be used in patients with established, current or past history of ischaemic heart disease, peripheral arterial disease and/or cerebrovascular disease, or those with uncontrolled hypertension (European Medicines Agency letter No: EMA/84749/2014) [92]. These restrictions are unlikely to cause significant changes in the use of strontium ranelate in Hungary, as similar recommendations were in effect previously.

\subsubsection{Limitations of the study}

There are some limitations to our study. NHIF database does not provide full data access for research purposes, therefore the information on ICD codes and age of patients was not complete. Nevertheless, for our analysis ICD codes for the first 3 digits and 5-year-long age clusters were used. There might be some uncertainties derived from limited ICDs in the case of vitamin D and calcium prescriptions (E55-E58, vitamin deficiency), since the indication of use is widespread. However, M80 (osteoporosis with pathological fracture) and M81 (osteoporosis without pathological fracture) codes clearly and sufficiently refer to osteoporosis. Also, this database does not include over-the-counter medication claims. Thus, in this study we cannot estimate the OTC calcium and vitamin D consumption in Hungary.

\subsection{Medication use and fall prevalence among nursing home residents}

A retrospective cohort study was carried out over a period of five years (2010-2015) regarding the medication use and fall prevalence among nursing home residents in Szeged, Hungary. We found $27.9 \%$ annual fall prevalence rate among nursing home residents, which is slightly lower than the literature data. This fact bears evidence of the high-standard nursing care service the investigated nursing home provides. According to CDC and WHO reports, approximately $30-50 \%$ of people living in long-term care institutions fall each year, which is twice the rate of falls among community-dwelling older adults, and the frequency of falls increases with age $[1,3,93]$. Our results correspond to these findings: the age of 80 years and above was found to be statistically significant risk factor of falls, and fallers were 4 years older than non-faller residents on average. Therefore, attention should be paid to the $80+$ population, since they had almost a 4-fold risk of falling (odds ratio 3.92) compared to those who were under the age of 80 years. 
Although many geriatricians consider polypharmacy (defined as taking 4 or more chronic medications) to be unavoidable among older patients, PP was a significant risk factor of falls in our study, as it is supported by different surveys and reviews $[6,13,18]$.

Higher numbers of chronic medications was a predisposing factor for falls in male patients. This is an important finding, since fatal fall outcome rates are much higher in men $(46 \%)$ than in women $(27 \%)$ over the age of 65 years [94]. The underlying causes of higher incidence in men are not obvious. Some studies found that males suffer from more co-morbid conditions or they may fall from greater heights and, having poorer health status, they are less likely to survive a fall-related injury than women of comparable age [94, 95]. Among the potential causes, the greater rates of smoking and alcohol abuse in men, along with commoner causes of secondary osteoporosis (e.g., glucocorticoid excess and hypogonadism) can be mentioned $[65,66]$. As was highlighted earlier, the mortality rates are also nearly double in men than in women after sustaining a hip fracture [18, 23, 24, 29-32]. Thus guidelines and policies on fall prevention need to be designed on gender perspective, particularly in vulnerable nursing home populations.

As the most serious non-fatal consequence of falls, bone fractures occurred in 24 patients (43.6\% among fallers). Although huge differences can be seen in fracture rates worldwide, our study reports higher percentages than a Sweden study (1-33\%) or a US study $(10-25 \%)$ do, and lower than the one identified in a recent Australian paper (about 48\%) [96-98].

One possible way of reducing fall risk (and consequences) of elderly patients is the frequent and regular medication review, as some of the medications are considered potentially inappropriate for elderly people $[17,58-60]$. Although our results did not show a difference in the number of overall PIM-use between fallers and non-fallers, three active agents have emerged from the others. Neither trimetazidine nor vinpocetine have been considered as PIM agents in the literature previously. Pantoprazole was included in the 2015 Beers criteria, but was not included in any PIM lists before. The updated Beers criteria suggests the avoidance of the use of pantoprazole beyond 8 weeks without justification, since long-term proton-pump inhibitor exposure carries high risk of Clostridium difficile infection, bone loss and fractures. Thus, our empirical findings extend the relevancy of pantoprazole being mentioned as a PIM agent with a new aspect: its use showed 2.5-fold risk of falls compared to non-takers, and one in every six patients would be expected to experience a fall (NNH value 5.9). As stated in the summary of product characteristics (SPC), severe hypomagnesaemia has been reported in 
patients, causing fatigue, tetany, delirium, convulsions and dizziness, especially on long-term use (more than 3 months), which can directly lead to geriatric falls [99]. As pantoprazole is an extensively used proton pump inhibitor, its side effects are widely studied. In fact, several recent articles suggest that its use in high doses over long durations ( $>1$ year) may modestly increase the risk of bone fractures; thus, patients at risk of osteoporosis should receive adequate intake of calcium and vitamin D and should be kept under regular surveillance [99, $100]$.

Both vinpocetine (nootropic agent) and trimetazidine (anti-anginal agent) can have side effects that may increase the risk of falls, such as tremors, gait instability and dizziness [101103]. However, we could not find any research that would confirm the direct association between falls and the use of these medications. Our results from the binary logistic regression analysis revealed that taking vinpocetine will double the risk of falls (odds ratio 2.32), and the obtained NNH values suggest that every fourth or fifth exposure to trimetazidine or vinpocetine will result in a fall - within the given circumstances. We would like to emphasise that the role of trimetazidine as a risk factor for falls was confirmed only by univariate analysis. Larger patient numbers are necessary to support this finding, since the more robust multivariate analysis did not confirm this result. The use of tiapride (PPV (CI 95\%) 0.43 (0.27-0.60), atorvastatin $0.41(0.27-0.58)$ or isosorbide mononitrate $0.45(0.26-0.65)$ was found to be a statistically non-significant (as the confidence interval overlap the average annual fall rate), but still mentionable risk for falls.

Our methods applied in this study would fit in larger population analysis as well, and it may allow us deeper understanding of the role of each medication (or their combinations) concerning falls, especially as geriatric falls are multifactorial. Hence an explicit detachment of the causative circumstances is challenging. Physical state, impaired balance and gait, older age, visual impairment, cognitive decline and environmental factors all carry remarkable fall risk $[6,18]$. Despite these facts, the most broadly examined iatrogenic risk factors are polypharmacy and PIM use, since those are closely associated with ageing [9, 13-15, 17, 61]. As mentioned earlier, wider, comprehensive epidemiological studies would be necessary to confirm the role of particular active agents, and to help professionals prescribe, evaluate and review geriatric medication use based on real-life epidemiological data. Our results may contribute to and inspire further research in this field. 


\subsubsection{Limitations of the study}

The source of data for our analysis came from the same nursing home, and we did not have access to the medical information of deceased patients. This limitation may cause some bias in our results. Furthermore, while some falls may have remained hidden and unreported for any reason, the documented cases were well-established. Finally, larger patient data are needed to confirm our findings, since we had relatively small sample sizes for epidemiological analyses.

\subsection{Vitamin D levels of elderly hospitalised patients}

Serum vitamin D levels of old, hospitalised, hip fractured patients were compared to non-fractured hospitalised patients in a prospective pilot study. Although cholecalciferol level was measured during summertime, the insufficiency was markedly presented in both patient groups, and was higher in the fractured group. Prevalence of vitamin D deficiency was more than double in the fractured group. Correspondently, the mean vitamin D level was slightly higher in the control group. Falls were prevalent in both investigated groups: nearly 55\% of fractured patients and roughly one-third of controls reported multiple falls in the previous year. However, the statistical significance could not be verified of these findings, some conclusions might be made.

Many articles call our attention to the moderate or serious vitamin D hypovitaminosis, which affects the majority of the European, Asian and American population, mainly the elderly. In a Dutch study, serious $25(\mathrm{OH}) \mathrm{D}_{3}$ deficiency was noticed $(<25 \mathrm{nmol} / \mathrm{L}$ range was used) in $2-30 \%$ of adults, increasing in the elderly and institutionalised to more than $80 \%$ across Europe [104]. According to the National Health and Nutrition Examination Survey (NHANES) in non-Hispanic white Americans mean serum 25(OH) $\mathrm{D}_{3}$ was about $65 \mathrm{nmol} / \mathrm{L}$, but only $40 \mathrm{nmol} / \mathrm{L}$ in non-Hispanic blacks and Mexican-Americans [105]. Approximately $10 \%$ of the inhabitants have been suffering from extreme serious hypovitaminosis D in the USA $(<25 \mathrm{nmol} / \mathrm{L})$ [106]. Suboptimal vitamin D levels are also common in Hungary. A recent study of the Semmelweis University (Budapest, Capital region of Hungary) analysed the results of a one-year long survey (from 2009 to 2010), which has involved nearly 6000 patients. Suboptimal vitamin D level $(<75 \mathrm{nmol} / \mathrm{L})$ occurred in $72 \%$, while the rate of serious deficiency was $12 \%$ ( $<35 \mathrm{nmol} / \mathrm{L})$ [107]. Another Hungarian survey found $32 \%$ vitamin D insufficiency $(<75 \mathrm{nmol} / \mathrm{L})$ and $9.6 \%$ deficiency $(<50 \mathrm{nmol} / \mathrm{L})$ rates among healthy 
blood donors in Vas County during summertime. Over 43 years, suboptimal vitamin D levels were more prevalent, $57 \%$ in females and $67 \%$ in males [108].

The role of $25(\mathrm{OH}) \mathrm{D}_{3}$ vitamin in calcium and bone homeostasis is well-known - its main effects on the bone metabolism include: the increase of calcium absorption from the intestine, the activation of osteoblasts, differentiation of osteoclasts and the inhibition of parathyroid hormone synthesis [109, 110]. Adequate vitamin D status is elementary part of treating osteoporosis in both women and men. However, numerous studies refer to the extraskeletal functions of vitamin D, verifying various systemic effects of it (see Introduction section). The vitamin D receptor (a member of the nuclear steroid hormone receptor family) is almost universally expressed in nucleated cells, and the expression of several hundred known cytokines and molecules is being influenced by cholecalciferol [111-113]. Thus it may be treated as a hormone rather than a vitamin [114-117].

Several lines of evidence support the concept that vitamin D is essential for maintaining muscle strength and coordination, for example the fact that genetic depletion of the receptor can lead to poor muscle function in mice [118]. Also, the high degree of muscle weakness in heritable conditions of vitamin D resistance and impaired receptor function confirms the strong and direct effect of vitamin D on muscles [119-121]. Vitamin D administration can improve the grip strength, the maximum voluntary contraction and maximal relaxation rate of quadriceps muscle, as well as the knee extension strength in patients with hypovitaminosis [122-124]. Thus, vitamin D supplementation may improve falls, as functional outcomes. In a meta-analysis vitamin D was associated with statistically significant reduction in the risk of falls (odds ratio 0.86), showing more reduction in deficient patients and when calcium was co-administered [40]. Vitamin D supplementation with calcium reduced the prevalence of hip fractures more effectively in community-dwelling elderly, than without calcium [125]. Vitamin D alone did not affect the mortality rate in old patients, but the risk of death was reduced if vitamin D was given with calcium in a Danish cohort [126].

Nevertheless, optimal serum concentration levels of vitamin D, with respect to its extraosseal effects, are still debated. The British National Osteoporosis Society (NOS) suggests that serum $25(\mathrm{OH}) \mathrm{D}_{3}>50 \mathrm{nmol} / \mathrm{L}(20 \mathrm{ng} / \mathrm{ml})$ is sufficient for almost the whole population [127]. The most recent Bischoff-Ferrari study set out 50-75 nmol/L (20-30 ng/ml) serum level as on optimal range, since higher serum vitamin D levels (over $111 \mathrm{nmol} / \mathrm{L}$ ) were associated with more than 5 times higher risk of falls compared to the deficient group [128]. An epidemiological study reported higher morbidity and mortality rates in patients both under 
and over the level of $50-90 \mathrm{nmol} / \mathrm{L}$ serum vitamin D [129]. For reaching the desirable $50 \mathrm{nmol} / \mathrm{L}$ value, the Institute of Medicine recommends $600 \mathrm{IU}$ (international units) daily vitamin D intake between the ages of 19-70, and 800 IU per day over 70 years [130]. At the same time, under 70 years in males and under 50 years in females $1000 \mathrm{mg}$ daily calcium intake is suggested, and $1200 \mathrm{mg}$ over those ages - European recommendations suggest only 700-800 $\mathrm{mg}$ of calcium [39, 130]. The International Osteoporosis Foundation (IOF) and the USPSTF (U.S. Preventive Services Task Force) evaluated the fall-risk reducing effects of daily 800-1000 IU vitamin D intake 'convincing' over 60 and 65 years $[131,132]$. The Endocrine Society (ENDO) suggests general vitamin D supplementation of 800 IU over 65 years to prevent falls [133]. The ENDO considers the optimal vitamin D level to be above $75 \mathrm{nmol} / \mathrm{L}$, and it can be reached by giving 1500-2000 IU daily amount, and continue as maintenance therapy [133]. The Hungarian guidelines (issued in 2012) agree with this standpoint, yet the workgroups of the consensus did not distinguish 'elderly' from 'adult' [116]. On the other hand, none of the health organisations recommend extreme amounts of vitamin $\mathrm{D}$ intake for extra-osseal purposes. In two studies, high dose vitamin $\mathrm{D}$ treatment (500,000 IU once yearly and 60,000 IU monthly) was associated with increased risk of falls, while it was not associated with better lower extremity function [128, 134].

With respect to the origin of vitamin $\mathrm{D}$, the IOF prioritises natural sources (UVB radiation, diet), supplemented by pharmacological vitamin D products if needed [131]. The main vitamin D source for the majority of the population is the sunlight UVB exposure, rather than diet $[131,135]$. Various environmental factors influence the amount of UVB radiation, such as latitude, weather conditions, duration of sunlight exposure, etc. [136]. The most endangered groups under the greatest risk of vitamin D deficiency are infants and children under 5 years, pregnant and breastfeeding women, old people aged 65 years and over, people who have low or no exposure of sunlight (who are housebound or confined indoors for long periods, people who have darker skin, or those who cover their skin for cultural reason) [137]. Also, winter season is a strong determinant almost everywhere [138].

Vitamin D treatment is essential for the populations at risk, but several precautions can be taken into account. In contrast with certain previous views, vitamin D supplementation in general populations is not recommended. Moreover, if the optimal range of vitamin D level is truly between $50-75 \mathrm{nmol} / \mathrm{L}$, widespread screening of the population is essential before the initiation of general supplementation programme, since it is not reasonable or even riskful for people within the optimal range $[39,132,133]$. Several trials are in progress to clarify the role 
and the optimal range of vitamin D under different conditions, such as cardiovascular diseases, cancer, diabetes or fracture [139].

Based on the above, we can come to the conclusion that in our study, more than $50 \%$ of fractured patients and about one-third of controls should receive vitamin D supplementation and it should be between 1500-2000 IU per day until the desirable range is reached. If available, UVB exposure and dietary sources should be also implemented to the supplementation therapy. The current recommendations do not suggest higher doses than 800 IU daily vitamin D over 70 years as maintenance dose -not even to prevent falls. Giving a maximum dose of $1000 \mathrm{mg}$ calcium per day may also be considered.

\subsubsection{Limitations of the study}

There are some limitations to our study. Firstly, the number of patients was relatively small for an epidemiological study. Nonetheless, this pilot study may provide useful information for the health care professionals about the vitamin D status of hospitalised elderly patients. Secondly, lack of patient data also limited our analysis. As falls are multifactorial, detailed patient history (e.g. medication history, body mass indices) would have been more informative, as well as performing grip strength test or walking test may improve the standard of this study. 


\section{SUMMARY AND CONCLUSIONS}

Falls are prevalent among elderly people, leading to hospital trauma admissions and early death. Osteoporotic fractures, as a consequences of geriatric falls, are responsible for high hospital admission- and mortality rates worldwide, significantly affect quality of life, and put huge financial burden on the society. Undoubtedly, postmenopausal women are under the greatest risk of osteoporotic bone fractures; however, outcomes are even much worse among male patients. A retrospective gender- and age-specific drug utilisation analysis of this study showed that men are significantly undertreated with medications indicated for the treatment of osteoporosis in all age groups, compared to women. The 10 to 20 -fold difference calls our attention to this unrecognised problem and to the need for extended screening aids. The incidence of hip fractures in Hungary showed an exponentially growing tendency with age in our study, therefore adjusting the trend of anti-osteoporotic medications to the population under the greatest risk (population over 80 years) would be considerable in both men and women. Also, based on our results, screening for osteoporosis in earlier ages, ideally 2 or 3-yearly after menopause in women, and over 65 years in men may accurately identify those individuals who need medication treatment. The earlier initiation of appropriate osteoporosis therapy could prevent fractures in older ages and may improve mortality rates. Our research is the first study that provides both age- and gender-specific information on the use of anti-osteoporotic medications in Hungary, and according to our knowledge there is no such study freely available across Europe. We hope this study will be helpful not only for Hungarian colleagues, but also a gap-filling work for other health care professionals in Europe.

Nursing home residents are especially endangered by falls, about 30-50\% of people living in long-term care institutions fall each year, which is twice the rate of falls among community-dwelling older adults. Appropriate medication use is a basic factor in terms of falls, as some drugs may carry increased risk of falling. We performed a retrospective cohort study regarding medication use and fall risk among nursing home residents. Older age (80 years or above), polypharmacy, and the independent use of 3 active agents (pantoprazole, vinpocetine and trimetazidine) were found to be major risk factors for falls. Neither trimetazidine nor vinpocetine have been considered as PIM agents in the literature previously. High numbers of chronic medications taken was a significant risk factor in male patients. Our results showed that polypharmacy itself could be defined as an independent risk 
factor for falls. Nevertheless, the benefit-to-risk ratio of fall-risk drugs also should be taken into account for safe prescribing. Drug-related problems can be reduced by means of the potentially inappropriate medication lists; however, these theoretical criteria need to be confirmed by real-life epidemiological data. Our methods and results could serve as a strong base for further research in this field, as well as they can attract health care professionals' attention to the most vulnerable populations of elderly patients in terms of falls.

The role of vitamin D in calcium and bone homeostasis is well-known. However, many research papers are dedicated and growing attention is oriented to the pleiotropic (extraskeletal) effects of $25(\mathrm{OH}) \mathrm{D}_{3}$. Vitamin $\mathrm{D}$ insufficiency is associated with decreased muscleand grip strength, higher incidence of falls, cancer, diabetes, autoimmune- or cardiovascular diseases in numerous articles. In our prospective pilot study, serum vitamin D levels of elderly hospitalised, hip fractured patients were compared to non-fractured hospitalised patients. Although cholecalciferol level was measured during summertime, the insufficiency was markedly presented in both patient groups, and was higher (more than double) in the fractured group, yet we could not prove the statistical significance. Also, falls were prevalent in both investigated groups. Based on the current, evidence based guidelines, elderly people under the normal cholecalciferol level $(30 \mathrm{ng} / \mathrm{ml}$ or $75 \mathrm{nmol} / \mathrm{L}$ ) should receive vitamin $\mathrm{D}$ supplementation for both skeletal and extra-skeletal purposes. Nevertheless, high dose boluses should be avoided, because extreme amounts of vitamin D intake may increase the risk of falls. Sunlight exposure and dietary sources are highly recommended as part of the supplementation therapy. 


\section{Key messages and novelties}

\section{Gender- and age-specific utilisation study of anti-osteoporotic drugs}

- Osteoporosis in no longer the condition of postmenopausal women, significant portion of men is also affected, and survival rate of hip fractures is worse in men.

- Males over 65 years should be also screened for osteoporosis and treated accordingly.

- Pharmacological fracture prevention may be started in earlier ages to reduce late-age incidence of hip fractures in both genders. This intervention may improve mortality rates and decrease fracture-related costs.

\section{Medication use and fall prevalence among nursing home residents}

- Geriatric falls are prevalent among individuals living in long-term care institutions, and are the leading causes of injury-related deaths.

- Older age, polypharmacy, and the independent use of 3 active agents (pantoprazole, vinpocetine and trimetazidine) were found to be major risk factors for falls in our study.

- Frequent and regular medication review is one possible way to reduce the risk of falling in elderly patients.

\section{Vitamin D levels of elderly hospitalised patients}

- Suboptimal vitamin D levels are prevalent among hospitalised older adults, as well as the prevalence of falls: nearly $55 \%$ of fractured patients and roughly one-third of controls reported multiple falls in the previous year.

- Vitamin D insufficiency was higher among hip fractured patient compared to controls; however we cannot prove the statistical significance.

- Based on current guidelines, elderly people under the normal cholecalciferol level (30 ng/ml or $75 \mathrm{nmol} / \mathrm{L}$ ) should receive vitamin D supplementation. 


\section{ACKNOWLEDGEMENTS}

First of all, I would like to express my sincere gratitude to my tutor and supervisor Prof. Dr. Gyöngyvér Soós, for her support and guidance of my Ph.D. study and related research, for her advices, criticism and immense knowledge. I am grateful to her commitment towards pharmacy and education.

I am indebted to my friend and supervisor Dr. Péter Doró, for his motivation, patience and continuous encouragement. His guidance and innovative way of thinking helped me in all the time of research and writing of this thesis. I could not have imagined having a better advisor and mentor for my Ph.D. study.

My special thanks go to Dr. Mária Matuz, my colleague and advisor, for her neverending endurance and invaluable statistical assistance of my research. I could not finish my Ph.D. work without her inspiration and unceasing support. I express my thanks to Dr. Nóra Gyimesi, Dr. Márta Csatordai, Dr. Zsuzsanna Biczók and Dr. Gábor Szalai, my closest colleagues, co-authors and friends for their technical assistance and for the cosy work-atmosphere. I am deeply grateful to all my co-authors for their collaboration and help in this work: Dr. Ria Benkő, Dr. Réka Viola and Dr. András Bálint.

It is a great pleasure to acknowledge my deep appreciation to all members of the University of Toledo, especially to Johnnie Lee Early, dean and professor, for the fantastic opportunity for me to work at the UT. My special thanks go to Dr. Martin Ohlinger, my friend and preceptor, for his guidance and motivation, as well as to my friends, Dr. Gabriella Baki and Dr. Amanda Bryant-Friedrich for their acceptance and immense inspiration.

I would like to express my gratitude to Éva Erdélyiné and Marietta Balázsi for their numberless help, humour and encouragement.

My sincere thanks also go to my friend and colleague Dr. Henriett Diána Szücs. Her everlasting support and her practical, realistic way of thinking highly inspired me in my decisions.

I would like to give special thanks to Dr. János Karsai. He played a key role in that I ended up dedicating a career to research and education.

Last but not least, I also wish to thank my dearest friends and family for their constant support, encouragement and patience. 


\section{REFERENCES}

[1] Centers for Disease Control and Prevention Falls in Nursing Homes (2016). Available at: http://www.cdc.gov/HomeandRecreationalSafety/Falls/ nursing.html. Accessed 02 Aug 2016.

[2] Phelan EA, Aerts S, Dowler D et al. Adoption of Evidence-Based Fall Prevention Practices in Primary Care for Older Adults with a History of Falls. Front Public Health 2016; 4: 190.

[3] World Health Organization Global report on falls prevention in older age (2007). Available at: http://www.who.int/ageing/projects/ falls_prevention_older_age/en/. Accessed 22 Aug 2016.

[4] Ambrose AF, Cruz L, Paul G. Falls and Fractures: A systematic approach to screening and prevention. Maturitas 2015; 82: 85-93.

[5] United Nations, Department of Economic and Social Affairs, Population Division (2015). World Population Prospects: The 2015 Revision, Key Findings and Advance Tables. Working Paper No. ESA/P/WP.241. Available at: https://esa.un.org/unpd/wpp/Publications/Files/Key_Findings_WPP _ 2015.pdf Accessed 23 Aug 2016.

[6] Freeland KN, Thompson AN, Zhao Y et al. Medication use and associated risk of falling in a geriatric outpatient population. Ann Pharmacother 2012; 46: 1188-92.

[7] Fialova D, Topinkova E, Gambassi G et al. Potentially inappropriate medication use among elderly home care patients in Europe. JAMA 2005; 293: 1348-58.

[8] Wu TY, Chie WC, Yang RS et al. Factors associated with falls among community-dwelling older people in Taiwan. Ann Acad Med Singapore 2013; 42: 320-7.

[9] Weber V, White A, McIlvried R. An electronic medical record (EMR)-based intervention to reduce polypharmacy and falls in an ambulatory rural elderly population. J Gen Intern Med 2008; 23: 399-404.

[10] Willeboordse F, Grundeken LH, van den Eijkel LP et al. Information on actual medication use and drug-related problems in older patients: questionnaire or interview? Int J Clin Pharm 2016; 38: 380-7.

[11] Chau SH, Jansen AP, van de Ven PM et al. Clinical medication reviews in elderly patients with polypharmacy: a cross-sectional study on drug-related problems in the Netherlands. Int J Clin Pharm 2016; 38: 46-53.

[12] Ziere G, Dieleman JP, Hofman A et al. Polypharmacy and falls in the middle age and elderly population. Br J Clin Pharmacol 2006; 61: 218-23.

[13] Zia A, Kamaruzzaman SB, Tan MP. Polypharmacy and falls in older people: Balancing evidencebased medicine against falls risk. Postgrad Med 2015; 127: 330-7.

[14] Hajjar ER, Cafiero AC, Hanlon JT. Polypharmacy in elderly patients. Am J Geriatr Pharmacother 2007; 5: 345-51.

[15] Ambrose AF, Paul G, Hausdorff JM. Risk factors for falls among older adults: a review of the literature. Maturitas 2013; 75: 51-61.

[16] Beers MH, Ouslander JG, Rollingher I et al. Explicit criteria for determining inappropriate medication use in nursing home residents. UCLA Division of Geriatric Medicine. Arch Intern Med 1991; 151: 1825-32.

[17] American Geriatrics Society 2015 Updated Beers Criteria for Potentially Inappropriate Medication Use in Older Adults. J Am Geriatr Soc 2015; 63: 2227-46.

[18] Cawthon PM. Gender differences in osteoporosis and fractures. Clin Orthop Relat Res 2011; 469: 1900-5.

[19] NIH Consensus Development Panel on Osteoporosis Prevention, Diagnosis, and Therapy. JAMA 2001; 285: 785-95.

[20] Jayasinghe JA, Jones SJ, Boyde A. Three-dimensional photographic study of cancellous bone in human fourth lumbar vertebral bodies. Anat Embryol (Berl) 1994; 189: 259-74. 
[21] Hadji P, Jacob L, Kostev K. Gender- and age-related treatment compliance in patients with osteoporosis in Germany. Patient Prefer Adherence 2016; 10: 2379-85.

[22] Center JR, Nguyen TV, Schneider D et al. Mortality after all major types of osteoporotic fracture in men and women: an observational study. Lancet 1999; 353: 878-82.

[23] Hernlund E, Svedbom A, Ivergard M et al. Osteoporosis in the European Union: medical management, epidemiology and economic burden. A report prepared in collaboration with the International Osteoporosis Foundation (IOF) and the European Federation of Pharmaceutical Industry Associations (EFPIA). Arch Osteoporos. 2013;8:136.

[24] Bor A, Matuz M, Gyimesi N et al. Gender inequalities in the treatment of osteoporosis. Maturitas. 2015;80:162-9.

[25] Hungarian Society of Osteoporosis and Osteoarthrology. [Recognition, prevention and treatment of osteoporosis] (Article in Hungarian) Ca \& Bone 2008;11: 4-56.

[26] Wilk R, Skrzypek M, Kowalska M et al. Standardized incidence and trend of osteoporotic hip fracture in Polish women and men: a nine year observation. Maturitas 2014; 77: 59-63.

[27] Willems JM, de Craen AJ, Nelissen RG et al. Haemoglobin predicts length of hospital stay after hip fracture surgery in older patients. Maturitas 2012; 72: 225-8.

[28] Forsen L, Sogaard AJ, Meyer HE et al. Survival after hip fracture: short- and long-term excess mortality according to age and gender. Osteoporos Int 1999; 10: 73-8.

[29] Floris I, Belicza E. [Analysis of hip fracture care in Hungary between 2004-2009]. Orv Hetil 2016; 157: 1642-8.

[30] Schnell S, Friedman SM, Mendelson DA et al. The 1-year mortality of patients treated in a hip fracture program for elders. Geriatr Orthop Surg Rehabil 2010; 1: 6-14.

[31] Bliuc D, Nguyen ND, Milch VE et al. Mortality risk associated with low-trauma osteoporotic fracture and subsequent fracture in men and women. JAMA 2009; 301: 513-21.

[32] Brauer CA, Coca-Perraillon M, Cutler DM, Rosen AB. Incidence and mortality of hip fractures in the United States. JAMA 2009; 302: 1573-9.

[33] Horváth C. [Osteoporosis - not only disease, but investment?] (2008) (Article in Hungarian). Available at: http://hetivalasz.hu/pr/a-csontritkulas-nemcsak-betegseg-hanem-befektetes-is38258/ ?cikk_ertekel=1\& ertekeles=1. Accessed 24 Aug 2016.

[34] Bischoff-Ferrari HA, Giovannucci E, Willett WC et al. Estimation of optimal serum concentrations of 25-hydroxyvitamin D for multiple health outcomes. Am J Clin Nutr 2006; 84: $18-28$.

[35] Lips P. Vitamin D deficiency and secondary hyperparathyroidism in the elderly: consequences for bone loss and fractures and therapeutic implications. Endocr Rev 2001; 22: 477-501.

[36] Wang S. Epidemiology of vitamin D in health and disease. Nutr Res Rev 2009; 22: 188-203.

[37] Muldowney S, Kiely M. Vitamin D and cardiometabolic health: a review of the evidence. Nutr Res Rev 2011; 24: 1-20.

[38] Schierbeck LL, Rejnmark L, Tofteng CL et al. Vitamin D deficiency in postmenopausal, healthy women predicts increased cardiovascular events: a 16-year follow-up study. European journal of endocrinology / European Federation of Endocrine Societies 2012; 167: 553.

[39] Bajnok L. [Vitamin D and calcium in the mirror of clinical evidence]. Orv Hetil 2016; 157: 12427.

[40] Murad MH, Elamin KB, Abu Elnour NO et al. Clinical review: The effect of vitamin D on falls: a systematic review and meta-analysis. J Clin Endocrinol Metab 2011; 96: 2997-3006.

[41] ICD-10 Classification. World Health Organization. Available at: http://www.who.int/ classifications/ icd/en/. Accessed 23 Aug 2016.

[42] Estonian drug consumption database. Available at: http://pxweb.tai.ee/esf/pxweb2008/ Database_en/Medicines/Medicines/Medicines.asp. Accessed 14 April 2014. 
[43] Finnish Medicines Agency Fimea and Social Insurance Institution (2010) Finnish statistics on medicines 2009. Finnish Medicines Agency, Helsinki, ISSN 0786-2180

[44] Finnish Medicines Agency Fimea and Social Insurance Institution (2011) Finnish statistics on medicines 2010. Finnish Medicines Agency, Helsinki ISSN 0786-2180

[45] Finnish Medicines Agency Fimea and Social Insurance Institution (2012) Finnish statistics on medicines 2011. Finnish Medicines Agency, Helsinki ISSN 0786-2180

[46] Estonian State Agency of Medicines. Baltic Statistics on Medicines 2010-2012. Estonian State Agency of Medicines, Tartu, 2013. ISBN 978-9949-33-396-7

[47] Norwegian Prescription Database. Available at: http://www.norpd.no/Prevalens.aspx. Accessed 20 May 2014.

[48] Birkett DJ. The future of ATC/DDD and drug utilization research. WHO Drug Information 2002;16: 238-40.

[49] Guidelines for ATC classification and DDD assignment 2013. Norwegian Institute of Public Health, Oslo ISBN 978-82-8082-525-4, Available at: http://www.whocc.no/filearchive/ publications/1_2013guidelines.pdf. Accessed 24 Aug 2016.

[50] The IUPHAR compendium of basic principles for pharmacological research in humans 2014. IUPHAR Administrative Office, Irvine ISBN 0-9533510-6-X, Available at: http://www.iuphar.org/ files/Clinical\%20Division / HumanResearchCompendium2004.pdf Accessed 24 Aug, 2016.

[51] Hungarian Central Statistical Office. Available at: http://statinfo.ksh.hu/Statinfo/themeSelector. jsp?page $=2 \&$ szst=WNT. Accessed 24 Feb 2014.

[52] Tables of basic data on Hungarian health care. Available at: http://tea.gyemszi.hu/ Accessed 20 March 2014.

[53] Brunner LC, Eshilian-Oates L, Kuo TY. Hip fractures in adults. Am Fam Physician 2003; 67: $537-42$.

[54] Mercaldo ND, Lau KF, Zhou XH. Confidence intervals for predictive values with an emphasis to case-control studies. Stat Med 2007; 26: 2170-83.

[55] Altman DG, Bland JM. Diagnostic tests 2: Predictive values. BMJ 1994; 309: 102.

[56] Agresti A. Categorical Data Analysis. 2nd Edition. Wiley; 2002.

[57] Agresti A, Caffo B. Simple and effective confidence intervals for proportions and difference of proportions result from adding two successes and two failures. The American Statistician 2000;54:280-288.

[58] Laroche ML, Charmes JP, Merle L. Potentially inappropriate medications in the elderly: a French consensus panel list. Eur J Clin Pharmacol 2007; 63: 725-31.

[59] Holt S, Schmiedl S, Thurmann PA. Potentially inappropriate medications in the elderly: the PRISCUS list. Dtsch Arztebl Int 2010; 107: 543-51.

[60] Mann E, Bohmdorfer B, Fruhwald $\mathrm{T}$ et al. Potentially inappropriate medication in geriatric patients: the Austrian consensus panel list. Wien Klin Wochenschr 2012; 124: 160-9.

[61] Bor A, Matuz M, Doró P et al. [Drug-related problems in the elderly]. Orv Hetil 2012; 153: 192636.

[62] Bjerrum L, Rosholm JU, Hallas J, Kragstrup J. Methods for estimating the occurrence of polypharmacy by means of a prescription database. Eur J Clin Pharmacol 1997; 53: 7-11.

[63] Vieth R. What is the optimal vitamin D status for health? Prog Biophys Mol Biol 2006; 92: 2632.

[64] Hollingworth SA, Gunanti I, Nissen LM, Duncan EL. Secondary prevention of osteoporosis in Australia: analysis of government-dispensed prescription data. Drugs Aging 2010; 27: 255-64.

[65] Laurent M, Gielen E, Claessens $F$ et al. Osteoporosis in older men: recent advances in pathophysiology and treatment. Best Pract Res Clin Endocrinol Metab 2013; 27: 527-39. 
[66] Gielen E, Vanderschueren D, Callewaert F, Boonen S. Osteoporosis in men. Best Pract Res Clin Endocrinol Metab 2011; 25: 321-35.

[67] Kaufman JM, Audran M, Bianchi G et al. Efficacy and safety of strontium ranelate in the treatment of osteoporosis in men. J Clin Endocrinol Metab 2013; 98: 592-601.

[68] Boonen S, Lorenc RS, Wenderoth D et al. Evidence for safety and efficacy of risedronate in men with osteoporosis over 4 years of treatment: Results from the 2-year, open-label, extension study of a 2-year, randomized, double-blind, placebo-controlled study. Bone 2012; 51: 383-8.

[69] White SC, Atchison KA, Gornbein JA et al. Risk factors for fractures in older men and women: The Leisure World Cohort Study. Gend Med 2006; 3: 110-23.

[70] Lippuner K, Johansson H, Kanis JA, Rizzoli R. Remaining lifetime and absolute 10-year probabilities of osteoporotic fracture in Swiss men and women. Osteoporos Int 2009; 20: 113140.

[71] World Health Organisation life expectancy. Available at: http://apps.who.int/ gho/data/node.main.3 ?lang=en. Accessed 20 March 2014.

[72] Johnell K, Fastbom J. Undertreatment of osteoporosis in the oldest old? A nationwide study of over 700,000 older people. Arch Osteoporos 2009; 4: 17-23.

[73] Karjalainen J. Novel pulse-echo ultrasound methods for diagnostics of osteoporosis. Academic Dissertation 2011, University of Eastern Finland

[74] Schuit SC, van der Klift M, Weel AE et al. Fracture incidence and association with bone mineral density in elderly men and women: the Rotterdam Study. Bone 2004; 34: 195-202.

[75] FRAX test. Available at: https://www.shef.ac.uk/FRAX/. Accessed 24 April 2015.

[76] Cramer JA, Roy A, Burrell A et al. Medication compliance and persistence: terminology and definitions. Value Health 2008; 11: 44-7.

[77] Iolascon G, Gimigliano F, Moretti A et al. Rates and reasons for lack of persistence with antiosteoporotic drugs: analysis of the Campania region database. Clin Cases Miner Bone Metab 2016; 13: 127-30.

[78] Lakatos P, Takacs I, Marton I et al. A Retrospective Longitudinal Database Study of Persistence and Compliance with Treatment of Osteoporosis in Hungary. Calcif Tissue Int 2016; 98: 215-25.

[79] Gallagher AM, Rietbrock S, Olson M, van Staa TP. Fracture outcomes related to persistence and compliance with oral bisphosphonates. J Bone Miner Res 2008; 23: 1569-75.

[80] Kim HY, Kim JW, Kim SJ et al. Uncertainty of Current Algorithm for Bisphosphonate-related Osteonecrosis of the Jaw in Population-based Studies: A Systematic Review. J Bone Miner Res 2016.

[81] Solomon DH, Mercer E, Woo SB et al. Defining the epidemiology of bisphosphonate-associated osteonecrosis of the jaw: prior work and current challenges. Osteoporos Int 2013; 24: 237-44.

[82] [Prevention and treatment of bisphosphonate-induced osteonecrosis of the jaw] (Article in Hungarian) Stomatologia Hungarica 2014, 107:106-7.

[83] Hungarian guideline on prevention of osteoporosis. Available at: http://docplayer.hu/1417473220-melleklet-az-59-2015-xii-30-emmi-rendelethez-15-melleklet-a-31-2010-v-13-eumrendelethez-oszteoporozis-kovetkezteben-kialakulo.html. Accessed 20 Jan 2017.

[84] Donnelly E, Saleh A, Unnanuntana A, Lane JM. Atypical femoral fractures: epidemiology, etiology, and patient management. Curr Opin Support Palliat Care 2012; 6: 348-54.

[85] Shane E, Burr D, Abrahamsen B et al. Atypical subtrochanteric and diaphyseal femoral fractures: second report of a task force of the American Society for Bone and Mineral Research. J Bone Miner Res 2014; 29: 1-23.

[86] Patel RN, Ashraf A, Sundaram M. Atypical Fractures Following Bisphosphonate Therapy. Semin Musculoskelet Radiol 2016; 20: 376-81.. 
[87] Giusti A, Hamdy NA, Papapoulos SE. Atypical fractures of the femur and bisphosphonate therapy: A systematic review of case/case series studies. Bone 2010; 47: 169-80.

[88] Sanchez A, Blanco R. Osteonecrosis of the jaw (ONJ) and atypical femoral fracture (AFF) in an osteoporotic patient chronically treated with bisphosphonates. Osteoporos Int 2016.

[89] Lim HS, Kim CK, Park YS et al. Factors Associated with Increased Healing Time in Complete Femoral Fractures After Long-Term Bisphosphonate Therapy. J Bone Joint Surg Am 2016; 98: 1978-87.

[90] Méndez-Gil A, Prat-Fabregat S, Domingo-Trepat A et al. [What do we know about atypical fractures in patients on biphosphonates treatment? A literature review using a case series]. Rev Esp Cir Ortop Traumatol 2013; 57: 95-105.

[91] Center for Drug Evaluation and Research Food and Drug Administration: Background Document for Meeting of Advisory Committee for Reproductive Health Drugs and Drug Safety and Risk Management Advisory Committee. Available at: http://www.fda.gov/downloads/ AdvisoryCommittees/CommitteesMeetingMaterials/Drugs/DrugSafetyandRiskManagementAdvis oryCommittee/UCM270958.pdf. Accessed 30 Dec 2016.

[92] Compston J. Strontium ranelate lives to fight another day. Maturitas 2014; 78: 75-6.

[93] Rubenstein LZ. Preventing falls in the nursing home. JAMA 1997; 278: 595-6.

[94] Stevens JA. Falls among older adults--risk factors and prevention strategies. J Safety Res 2005; 36: 409-11.

[95] Fatalities and injuries from falls among older adults--United States, 1993-2003 and 2001-2005. MMWR Morb Mortal Wkly Rep 2006; 55: 1221-4.

[96] Fonad E, Wahlin TB, Winblad B et al. Falls and fall risk among nursing home residents. J Clin Nurs 2008; 17: 126-34.

[97] Rubenstein LZ. Falls in older people: epidemiology, risk factors and strategies for prevention. Age Ageing 2006; 35 Suppl 2: ii37-ii41.

[98] Russell M, Clapperton A, Vu T, Day L. Trends in fall-related hospitalisations in older people living in aged care facilities. Osteoporos Int 2015; 26: 1219-24.

[99] Pantoprazole Summary of Product Characteristics. https://www.medicines.org.uk/ emc/medicine/2518. Accessed 23 Jan 2017.

[100] Ozdil K, Kahraman R, Sahin A et al. Bone density in proton pump inhibitors users: a prospective study. Rheumatol Int 2013; 33: 2255-60.

[101] Vinpocetine Summary of Product Characteristics. https://www.ogyei.gov.hu/ gyogyszeradatbazis/ index.php?action=show_details\&item=16779. Accessed $24 \mathrm{Feb} 2016$.

[102] Trimetazidine Summary of Product Characteristics. https://www.ogyei.gov.hu /gyogyszeradatbazis/ index.php?action=show_details\&item=27756 Accessed 24 Feb 2016.

[103] European Medicines Agency Recommendation on restricted use of trime-tazidine-containing medicines. 2012. http://www.ema.europa.eu/ema/index.jsp?curl=pages/news_and_events/news/ 2012/06/news_detail_001541.jsp\&mid=WC0b01ac058004d5c1 Accessed 24 Feb 2016.

[104] Lips P. Vitamin D status and nutrition in Europe and Asia. J Steroid Biochem Mol Biol 2007; 103: 620-5.

[105] Looker AC, Pfeiffer CM, Lacher DA et al. Serum 25-hydroxyvitamin D status of the US population: 1988-1994 compared with 2000-2004. Am J Clin Nutr 2008; 88: 1519-27.

[106] Looker AC, Dawson-Hughes B, Calvo MS et al. Serum 25-hydroxyvitamin D status of adolescents and adults in two seasonal subpopulations from NHANES III. Bone 2002; 30: 7717.

[107] Vasarhelyi B, Satori A, Olajos F et al. Low vitamin D levels among patients at Semmelweis University: retrospective analysis during a one-year period. Orv Hetil 2011; 152: 1272. 
[108] Viragh E, Horvath D, Locsei Z et al. Vitamin D supply among healthy blood donors in Vas County, Hungary. Orv Hetil 2012; 153: 1629.

[109] Fonyó A. Physiology. Seventh edition 2014 ISBN 9789632265049

[110] Goodman \& Gilman's The Pharmacological Basis of Therapeutics. Twelfth edition 2011 ISBN: 9780071769396

[111] Bouillon R, Carmeliet G, Verlinden L et al. Vitamin D and human health: lessons from vitamin D receptor null mice. Endocr Rev 2008; 29: 726-76.

[112] Norman AW. Minireview: vitamin D receptor: new assignments for an already busy receptor. Endocrinology 2006; 147: 5542-8.

[113] Rosen CJ, Adams JS, Bikle DD et al. The nonskeletal effects of vitamin D: an Endocrine Society scientific statement. Endocr Rev 2012; 33: 456-92.

[114] Norman AW. From vitamin D to hormone D: fundamentals of the vitamin D endocrine system essential for good health. Am J Clin Nutr 2008; 88: 491S-9S.

[115] Tóth EA. [Pathogenesis and treatment of male osteoporosis.] Dissertation in Hungarian 2005. Semmelweis University Budapest

[116] Takacs I, Benko I, Toldy E et al. Hungarian consensus regarding the role of vitamin D in the prevention and treatment of diseases. Orv Hetil 2012; 153 Suppl: 5.

[117] Schlereth F, Badenhoop K. [Vitamin-D : More than just a bone hormone]. Internist (Berl) 2016; 57: 646-55.

[118] Christakos S, DeLuca HF. Minireview: Vitamin D: is there a role in extraskeletal health? Endocrinology 2011; 152: 2930-6.

[119] Panda DK, Miao D, Tremblay ML et al. Targeted ablation of the 25-hydroxyvitamin D 1alpha hydroxylase enzyme: evidence for skeletal, reproductive, and immune dysfunction. Proc Natl Acad Sci U S A 2001; 98: 7498-503.

[120] Adams JS, Hewison M. Update in vitamin D. J Clin Endocrinol Metab 2010; 95: 471-8.

[121] Dardenne O, Prudhomme J, Hacking SA et al. Rescue of the pseudo-vitamin D deficiency rickets phenotype of CYP27B1-deficient mice by treatment with 1,25-dihydroxyvitamin D3: biochemical, histomorphometric, and biomechanical analyses. J Bone Miner Res 2003; 18: 63743.

[122] Visser M, Deeg DJ, Lips P, Amsterdam LAS. Low vitamin D and high parathyroid hormone levels as determinants of loss of muscle strength and muscle mass (sarcopenia): the Longitudinal Aging Study Amsterdam. J Clin Endocrinol Metab 2003; 88: 5766-72.

[123] Gupta R, Sharma U, Gupta N et al. Effect of cholecalciferol and calcium supplementation on muscle strength and energy metabolism in vitamin D-deficient Asian Indians: a randomized, controlled trial. Clin Endocrinol (Oxf) 2010; 73: 445-51.

[124] Stockton KA, Mengersen K, Paratz JD et al. Effect of vitamin D supplementation on muscle strength: a systematic review and meta-analysis. Osteoporos Int 2011; 22: 859-71.

[125] Bolland MJ, Grey A, Gamble GD, Reid IR. The effect of vitamin D supplementation on skeletal, vascular, or cancer outcomes: a trial sequential meta-analysis. Lancet Diabetes Endocrinol 2014; 2: 307-20.

[126] Rejnmark L, Avenell A, Masud T et al. Vitamin D with calcium reduces mortality: patient level pooled analysis of 70,528 patients from eight major vitamin D trials. J Clin Endocrinol Metab 2012; 97: 2670-81.

[127] Francis RM, Aspray TJ, Bowring CE et al. National Osteoporosis Society practical clinical guideline on vitamin D and bone health. Maturitas 2015; 80: 119-21.

[128] Bischoff-Ferrari HA, Dawson-Hughes B, Orav EJ et al. Monthly High-Dose Vitamin D Treatment for the Prevention of Functional Decline: A Randomized Clinical Trial. JAMA Intern Med 2016; 176: 175-83. 
[129] Dror Y, Giveon SM, Hoshen M et al. Vitamin D levels for preventing acute coronary syndrome and mortality: evidence of a nonlinear association. J Clin Endocrinol Metab 2013; 98: 2160-7.

[130] Dietary Reference Intakes for Calcium and Vitamin D. Washington DC: National Academy of Sciences. 2011.

[131] IOF comments on US Task Force recommendations regarding vitamin D and calcium supplementation. Available at www.iofbonehealth.org/iof-comments-us-task-forcerecommendations-regarding-vitamin-d-and-calcium-supplementation Accessed 1 May 2016.

[132] Moyer VA, Force* USPST. Vitamin D and calcium supplementation to prevent fractures in adults: U.S. Preventive Services Task Force recommendation statement. Ann Intern Med 2013; 158: 691-6.

[133] Holick MF, Binkley NC, Bischoff-Ferrari HA et al. Evaluation, treatment, and prevention of vitamin D deficiency: an Endocrine Society clinical practice guideline. J Clin Endocrinol Metab 2011; 96: 1911-30.

[134] Sanders KM, Stuart AL, Williamson EJ et al. Annual high-dose oral vitamin D and falls and fractures in older women: a randomized controlled trial. JAMA 2010; 303: 1815-22.

[135] Calvo MS, Whiting SJ, Barton CN. Vitamin D intake: a global perspective of current status. J Nutr 2005; 135: 310-6.

[136] Spiro A, Buttriss JL. Vitamin D: An overview of vitamin D status and intake in Europe. Nutr Bull 2014; 39: 322-50.

[137] NICE (National Institute for Health and Clinical Excellence) (2013) Vitamin D: implementation of existing guidance to prevent deficiency. Available at: https://www.nice.org.uk/ guidance/ph56/documents/implementing-vitamin-d-guidance-final-scope-2. Accessed 02 April 2015.

[138] Lips P. Worldwide status of vitamin D nutrition. J Steroid Biochem Mol Biol 2010; 121: 297300.

[139] Kupferschmidt K. Uncertain verdict as vitamin D goes on trial. Science 2012; 337: 1476-8. 
SUPPLEMENT 
The Hungarian PIM list

\begin{tabular}{|c|c|c|c|c|c|c|c|c|c|}
\hline & Drug & $\begin{array}{l}\text { ATC } \\
\text { code }\end{array}$ & Reasons & Alternative drugs & $\begin{array}{l}\text { Beers } \\
2015\end{array}$ & $\begin{array}{l}\text { La- } \\
\text { Roche } \\
2007\end{array}$ & $\begin{array}{l}\text { Priscuss } \\
2010\end{array}$ & $\begin{array}{c}\text { Mann } \\
2011\end{array}$ & $\begin{array}{l}\text { Risk } \\
\text { of falls }\end{array}$ \\
\hline 1 & Liquid paraffin & A06АA01 & $\begin{array}{l}\text { Can lead to hypocalcaemia and } \\
\text { hypokalaemia, can lead to lipid } \\
\text { pneumonia in case of aspiration } \\
\text { pneumonia. }\end{array}$ & Lactulose, macrogol & $\mathbf{x}$ & & $\mathbf{x}$ & $\mathbf{x}$ & \\
\hline 2 & Bisacodyl & A06AB02 & Worsening of irritable bowel syndrome. & Osmotic laxatives & $\mathbf{x}$ & $\mathbf{x}$ & & $\mathbf{x}$ & \\
\hline 3 & Sennosides & A06AB06 & Worsening of irritable bowel syndrome. & Osmotic laxatives & & $\mathbf{x}$ & & & \\
\hline 4 & $\begin{array}{l}\text { Sodium } \\
\text { picosulfate }\end{array}$ & А06АВ08 & Worsening of irritable bowel syndrome. & Osmotic laxatives & & $\mathbf{x}$ & & & \\
\hline 5 & Docusate & A06AG10 & Worsening of irritable bowel syndrome. & Osmotic laxatives & & $\mathbf{x}$ & & & \\
\hline 6 & Diphenoxylate & A07DA01 & $\begin{array}{l}\text { Muscarinic-blocking agents. No proven } \\
\text { efficacy. }\end{array}$ & Mebeverine, phloroglucinol & $\mathbf{x}$ & & & & \\
\hline 7 & Glibenclamide & A10BB01 & $\begin{array}{l}\text { Long-acting sulphonylureas can cause an } \\
\text { increased risk of hypoglycaemia. }\end{array}$ & Short-acting sulphonylureas & & & & $\mathbf{x}$ & \\
\hline 8 & Ticlopidine & B01AC05 & $\begin{array}{l}\text { Can lead to life-threatening } \\
\text { haematological side effects, including } \\
\text { neutropenia/agranulocytosis, thrombotic } \\
\text { thrombocytopenic purpura, and aplastic } \\
\text { anaemia, may cause altered blood counts. }\end{array}$ & Clopidogrel, acetylsalicylic-acid & $\mathbf{x}$ & $\mathbf{x}$ & $\mathbf{x}$ & $\mathbf{x}$ & \\
\hline 9 & Prasugrel & B01AC22 & $\begin{array}{l}\text { May cause altered blood counts. } \\
\text { Unfavorable risk/benefit ratio, } \\
\text { particularly over } 75 \text { years. }\end{array}$ & Clopidogrel, acetylsalicylic-acid & & & $\mathbf{x}$ & & \\
\hline 10 & Ferrous sulfate & В03АA02 & & & $\mathbf{x}$ & & & & \\
\hline 11 & Digoxin & C01AA05 & $\begin{array}{l}\text { Increased sensitivity of the elderly. The } \\
\text { dose should remain } \leq 0.125 \mathrm{mg} / \text { day or } \\
\text { preferably should be adapted to maintain } \\
\text { serum concentration }<1.2 \mathrm{ng} / \mathrm{ml} \text {. Risk of } \\
\text { overdose in renal insufficiency: nausea, } \\
\text { vomiting, drowsiness, visual } \\
\text { disturbances, cardiac rhythm } \\
\text { disturbances. }\end{array}$ & $\begin{array}{l}\text { Digoxin dose } \leq 0.125 \mathrm{mg} / \text { day or } \\
\text { serum concentration between } \\
0.5 \text { and } 1.2 \mathrm{ng} / \mathrm{ml} .\end{array}$ & $\mathbf{x}$ & $\mathbf{x}$ & $\mathbf{x}$ & $\mathbf{x}$ & YES \\
\hline
\end{tabular}




\begin{tabular}{|c|c|c|c|c|c|c|c|c|c|}
\hline & Drug & $\begin{array}{l}\text { ATC } \\
\text { code }\end{array}$ & Reasons & Alternative drugs & $\begin{array}{l}\text { Beers } \\
2015\end{array}$ & $\begin{array}{l}\text { La- } \\
\text { Roche } \\
2007\end{array}$ & $\begin{array}{l}\text { Priscuss } \\
2010\end{array}$ & $\underset{2011}{\operatorname{Mann}}$ & $\begin{array}{c}\text { Risk } \\
\text { of falls }\end{array}$ \\
\hline 12 & Quinidine & C01BA01 & $\begin{array}{l}\text { Central nervous side effects, increased } \\
\text { mortality. Quinidine plus verapamil: not } \\
\text { recommended for patients over age } 75 \text {. } \\
\text { Monitoring for central nervous effects, } \\
\text { monitoring of cardiovascular function } \\
\text { (proarrhythmia, QT duration), monitoring } \\
\text { of renal function. }\end{array}$ & $\begin{array}{l}\text { Beta-blockers, verapamil, diltiazem, } \\
\text { amiodarone, defibrillator } \\
\text { implantation. }\end{array}$ & & & $\mathbf{x}$ & & \\
\hline 13 & Disopyramide & C01BA03 & Heart failure, anticholinergic effect. & Amiodarone, other antiarrhythmics & $\mathbf{x}$ & $\mathbf{X}$ & & & YES \\
\hline 14 & Propafenone & С01BC03 & $\begin{array}{l}\text { Pro-arrhythmogenic effect can lead to } \\
\text { AV block, intraventricular conduction } \\
\text { delays, common neurotoxic and } \\
\text { gastrointestinal side effects. }\end{array}$ & $\begin{array}{l}\text { Indication of cardioversion: } \\
\text { amiodarone, indication of frequency } \\
\text { control: beta-blockers, verapamil, } \\
\text { diltiazem, digitoxin. }\end{array}$ & & & & $\mathbf{x}$ & \\
\hline 15 & Flecainide & $\mathrm{C01BC04}$ & $\begin{array}{l}\text { Higher rate of adverse effects in general, } \\
\text { pro-arrhythmogenic effect can lead to } \\
\text { ventricular arrhythmias, ventricular } \\
\text { fibrillation and cardiac arrest. }\end{array}$ & $\begin{array}{l}\text { Beta-blockers, amiodarone, } \\
\text { verapamil, diltiazem, digitoxin. } \\
\text { Monitoring for central nervous } \\
\text { effects (e.g., vertigo, cognitive } \\
\text { impairment), monitoring of } \\
\text { cardiovascular function, monitoring } \\
\text { of renal function (dose adjustment). }\end{array}$ & & & $\mathbf{x}$ & $\mathbf{x}$ & YES \\
\hline 16 & Amiodarone & C01BD01 & $\begin{array}{l}\text { Common side effects: extra-pyramidal } \\
\text { tremors, insomnia, nightmares. Inhibition } \\
\text { of liver enzimes. }\end{array}$ & & $\mathbf{x}$ & & & & YES \\
\hline 17 & Dronedarone & C01BD07 & $\begin{array}{l}\text { Severe liver dysfunction up to liver } \\
\text { failure, increased mortality in patients } \\
\text { with heart failure, "reserve drug" for } \\
\text { amiodarone or beta-blockers in KI, } \\
\text { indication made by specialists. }\end{array}$ & $\begin{array}{l}\text { Indication of cardioversion: } \\
\text { amiodarone, indication of frequency } \\
\text { control: beta-blockers. }\end{array}$ & & & & $\mathbf{x}$ & \\
\hline 18 & Methyldopa & C02AB01 & $\begin{array}{l}\text { Can cause orthostatic hypotension, can } \\
\text { cause sedation. }\end{array}$ & & $\mathbf{x}$ & $\mathbf{x}$ & & $\mathbf{x}$ & YES \\
\hline 19 & Guanfacine & $\mathrm{CO2AC02}$ & $\begin{array}{l}\text { The aged are more sensitive to sedation, } \\
\text { hypotension, bradycardia, syncope. }\end{array}$ & $\begin{array}{l}\text { Other antihypertensive drugs, except } \\
\text { short-acting calcium-channel } \\
\text { blockers and reserpine. }\end{array}$ & & $\mathbf{x}$ & & & YES \\
\hline
\end{tabular}




\begin{tabular}{|c|c|c|c|c|c|c|c|c|c|}
\hline & Drug & $\begin{array}{l}\text { ATC } \\
\text { code }\end{array}$ & Reasons & Alternative drugs & $\begin{array}{l}\text { Beers } \\
2015\end{array}$ & $\begin{array}{l}\text { La- } \\
\text { Roche } \\
2007\end{array}$ & $\begin{array}{l}\text { Priscuss } \\
2010\end{array}$ & $\underset{2011}{\text { Mann }}$ & $\begin{array}{c}\text { Risk } \\
\text { of falls }\end{array}$ \\
\hline 20 & Moxonidine & $\mathrm{C02AC05}$ & $\begin{array}{l}\text { The aged are more sensitive to sedation, } \\
\text { hypotension, bradycardia, syncope. }\end{array}$ & $\begin{array}{l}\text { Other antihypertensive drugs, except } \\
\text { short-acting calcium-channel } \\
\text { blockers and reserpine. }\end{array}$ & & $\mathbf{x}$ & & & YES \\
\hline 21 & Rilmenidine & С02АC06 & $\begin{array}{l}\text { The aged are more sensitive to sedation, } \\
\text { hypotension, bradycardia, syncope. }\end{array}$ & $\begin{array}{l}\text { Other antihypertensive drugs, except } \\
\text { short-acting calcium-channel } \\
\text { blockers and reserpine. }\end{array}$ & & $\mathbf{x}$ & & & YES \\
\hline 22 & Prazosine & C02CA01 & $\begin{array}{l}\text { Aggravation of urinary incontinence, } \\
\text { postural hypotension. }\end{array}$ & $\begin{array}{l}\text { Monitoring of cardiovascular } \\
\text { function }\end{array}$ & & $\mathbf{x}$ & $\mathbf{x}$ & & YES \\
\hline 23 & Doxazosin & C02CA04 & $\begin{array}{l}\text { Hypotension (positional), dry mouth, } \\
\text { urinary incontinence/impaired } \\
\text { micturition. }\end{array}$ & $\begin{array}{l}\text { Monitoring of cardiovascular } \\
\text { function }\end{array}$ & $\mathbf{x}$ & & $\mathbf{x}$ & & YES \\
\hline 24 & Urapidil & C02CA06 & $\begin{array}{l}\text { Aggravation of urinary incontinence, } \\
\text { postural hypotension. }\end{array}$ & $\begin{array}{l}\text { Monitoring of cardiovascular } \\
\text { function }\end{array}$ & & $\mathbf{x}$ & & & YES \\
\hline 25 & Ethacrynic acid & $\mathrm{C03CC01}$ & Can cause postural hypotension. & & $\mathbf{x}$ & & & & YES \\
\hline 26 & Pentoxifylline & C04AD03 & Hypotension & & $\mathbf{x}$ & $\mathbf{x}$ & $\mathbf{x}$ & $\mathbf{x}$ & YES \\
\hline 27 & Nicergoline & C04AE02 & $\begin{array}{l}\text { No really proven efficacy while postural } \\
\text { hypotension and fall risks are increased } \\
\text { with most vasodilators. }\end{array}$ & & & $\mathbf{x}$ & $\mathbf{x}$ & $\mathbf{x}$ & YES \\
\hline 28 & Naftidrofuryl & C04AX21 & $\begin{array}{l}\text { No really proven efficacy while postural } \\
\text { hypotension and fall risks are increased } \\
\text { with most vasodilators. }\end{array}$ & & & $\mathbf{x}$ & $\mathbf{x}$ & $\mathbf{x}$ & YES \\
\hline 29 & Sotalol & C07АA07 & $\begin{array}{l}\text { Pro-arrhythmogenic effect, can lead to } \\
\text { torsade de pointes or ventricular } \\
\text { tachycardia/ventricular fibrillation, QT } \\
\text { interval prolongation, and accumulation } \\
\text { in patients with renal insufficiency. }\end{array}$ & $\begin{array}{l}\text { Other beta-blockers (except atenolol, } \\
\text { which has unfavourable data } \\
\text { regarding the endpoint of stroke). }\end{array}$ & & & $\mathbf{x}$ & $\mathbf{x}$ & \\
\hline 30 & Nifedipine & C08CA05 & $\begin{array}{l}\text { Postural hypotension, myocardial } \\
\text { infarction or stroke. }\end{array}$ & $\begin{array}{l}\text { Other antihypertensive drugs, except } \\
\text { centrally acting antihypertensives } \\
\text { and reserpine. }\end{array}$ & $\mathbf{x}$ & $\mathbf{x}$ & $\mathbf{x}$ & $\mathbf{x}$ & YES \\
\hline 31 & Oxybutynin & G04BD04 & $\begin{array}{l}\text { Can cause delirium and cognitive } \\
\text { impairment, can worsen glaucoma and } \\
\text { lead to partial or complete } \\
\text { gastrointestinal obstruction. }\end{array}$ & Trospium chloride & $\mathbf{x}$ & $\mathbf{x}$ & $\mathbf{x}$ & $\mathbf{x}$ & YES \\
\hline
\end{tabular}




\begin{tabular}{|c|c|c|c|c|c|c|c|c|c|}
\hline & Drug & $\begin{array}{l}\text { ATC } \\
\text { code }\end{array}$ & Reasons & Alternative drugs & $\begin{array}{l}\text { Beers } \\
2015\end{array}$ & $\begin{array}{l}\text { La- } \\
\text { Roche } \\
2007\end{array}$ & $\begin{array}{c}\text { Priscuss } \\
2010\end{array}$ & $\begin{array}{c}\text { Mann } \\
2011\end{array}$ & $\begin{array}{c}\text { Risk } \\
\text { of falls }\end{array}$ \\
\hline 32 & Tolterodine & G04BD07 & $\begin{array}{l}\text { Can cause delirium and cognitive } \\
\text { impairment, can worsen glaucoma and } \\
\text { lead to partial or complete } \\
\text { gastrointestinal obstruction. }\end{array}$ & Trospium chloride & & $\mathbf{x}$ & $\mathbf{x}$ & $\mathbf{x}$ & YES \\
\hline 33 & Solifenacin & G04BD08 & $\begin{array}{l}\text { Anticholinergic side effects (e.g., } \\
\text { constipation, dry mouth, CNS ), ECG } \\
\text { changes (prolonged QT). }\end{array}$ & & & $\mathbf{x}$ & $\mathbf{x}$ & & YES \\
\hline 34 & Terazosine & G04CA03 & $\begin{array}{l}\text { Increased risk of cerebrovascular and } \\
\text { cardiovascular disease. }\end{array}$ & & & & $\mathbf{x}$ & & \\
\hline 35 & Nitrofurantoin & J01XE01 & $\begin{array}{l}\text { Unfavorable risk/benefit ratio, } \\
\text { particularly with long-term use } \\
\text { (pulmonary side effects, liver damage, } \\
\text { etc.) }\end{array}$ & $\begin{array}{l}\text { Other antibiotics (e.g., } \\
\text { cephalosporins, cotrimoxazole, } \\
\text { trimethoprim-in accordance with } \\
\text { sensitivity and resistance testing, as } \\
\text { far as possible). Non- } \\
\text { pharmacological measures: more } \\
\text { fluid intake, incontinence aids. } \\
\text { Monitoring of renal, pulmonary, and } \\
\text { hepatic function. }\end{array}$ & $\mathbf{x}$ & $\mathbf{x}$ & $\mathbf{x}$ & & \\
\hline 36 & Celecoxib & L01XX33 & $\begin{array}{l}\text { Serious adverse drug reactions: } \\
\text { gastrointestinal ulcers, bleeding, kidney } \\
\text { and liver insufficiency, hypertension. }\end{array}$ & & & & & $\mathbf{x}$ & \\
\hline 37 & Indomethacin & M01AB01 & $\begin{array}{l}\text { Highest incidence of CNS side effects } \\
\text { (e.g. delirium) of all NSAIDs. Very high } \\
\text { risk of gastrointestinal haemorrhage. }\end{array}$ & Paracetamol or other NSAID. & $\mathbf{x}$ & $\mathbf{x}$ & $\mathbf{x}$ & $\mathbf{x}$ & \\
\hline 38 & Diclofenac & M01AB05 & $\begin{array}{l}\text { Serious adverse drug reactions: } \\
\text { gastrointestinal ulcers, bleeding, kidney } \\
\text { and liver insufficiency, hypertension. }\end{array}$ & $\begin{array}{l}\text { In the analgetic indication: } \\
\text { paracetamol, metamizole, } \\
\text { hydromorphone. }\end{array}$ & & & & $\mathbf{x}$ & \\
\hline 39 & Ibuprofen & M01AE01 & $\begin{array}{l}\text { Serious adverse drug reactions: } \\
\text { gastrointestinal ulcers, bleeding, kidney } \\
\text { and liver insufficiency, hypertension. }\end{array}$ & & & & & $\mathbf{x}$ & \\
\hline 40 & Acemetacin & M01AB11 & $\begin{array}{l}\text { Serious adverse drug reactions: } \\
\text { gastrointestinal ulcers, bleeding, kidney } \\
\text { and liver insufficiency, hypertension. }\end{array}$ & $\begin{array}{l}\text { In the analgetic indication: } \\
\text { paracetamol, metamizole, } \\
\text { hydromorphone. }\end{array}$ & & & $\mathbf{x}$ & $\mathbf{x}$ & \\
\hline
\end{tabular}




\begin{tabular}{|c|c|c|c|c|c|c|c|c|c|}
\hline & Drug & $\begin{array}{l}\text { ATC } \\
\text { code }\end{array}$ & Reasons & Alternative drugs & $\begin{array}{l}\text { Beers } \\
2015\end{array}$ & $\begin{array}{l}\text { La- } \\
\text { Roche } \\
2007\end{array}$ & $\begin{array}{l}\text { Priscuss } \\
2010\end{array}$ & $\begin{array}{c}\text { Mann } \\
2011\end{array}$ & $\begin{array}{l}\text { Risk } \\
\text { of falls }\end{array}$ \\
\hline 41 & Piroxicam & M01AC01 & $\begin{array}{l}\text { Serious adverse drug reactions: } \\
\text { gastrointestinal ulcers, bleeding, kidney } \\
\text { and liver insufficiency, hypertension. }\end{array}$ & $\begin{array}{l}\text { In the analgetic indication: } \\
\text { paracetamol, metamizole, } \\
\text { hydromorphone. }\end{array}$ & $\mathbf{x}$ & & $\mathbf{x}$ & $\mathbf{x}$ & \\
\hline 42 & Meloxicam & M01AC06 & $\begin{array}{l}\text { Serious adverse drug reactions: } \\
\text { gastrointestinal ulcers, bleeding, kidney } \\
\text { and liver insufficiency, hypertension. }\end{array}$ & $\begin{array}{l}\text { In the analgetic indication: } \\
\text { paracetamol, metamizole, } \\
\text { hydromorphone. }\end{array}$ & & & $\mathbf{x}$ & $\mathbf{x}$ & \\
\hline 43 & Naproxen & M01AE02 & $\begin{array}{l}\text { Serious adverse drug reactions: } \\
\text { gastrointestinal ulcers, bleeding, kidney } \\
\text { and liver insufficiency, hypertension. }\end{array}$ & $\begin{array}{l}\text { In the analgetic indication: } \\
\text { paracetamol, metamizole, } \\
\text { hydromorphone. }\end{array}$ & $\mathbf{x}$ & & & $\mathbf{x}$ & \\
\hline 44 & Ketoprofen & M01AE03 & $\begin{array}{l}\text { Serious adverse drug reactions: } \\
\text { gastrointestinal ulcers, bleeding, kidney } \\
\text { and liver insufficiency, hypertension. }\end{array}$ & $\begin{array}{l}\text { In the analgetic indication: } \\
\text { paracetamol, metamizole, } \\
\text { hydromorphone. }\end{array}$ & & & $\mathbf{x}$ & $\mathbf{x}$ & \\
\hline 45 & $\begin{array}{l}\text { Mefenamic } \\
\text { acid }\end{array}$ & M01AG01 & $\begin{array}{l}\text { Serious adverse drug reactions: } \\
\text { gastrointestinal ulcers, bleeding, kidney } \\
\text { and liver insufficiency, hypertension. }\end{array}$ & $\begin{array}{l}\text { In the analgetic indication: } \\
\text { paracetamol, metamizole, } \\
\text { hydromorphone. }\end{array}$ & $\mathbf{x}$ & & & & \\
\hline 46 & Etoricoxib & M01AH05 & Cardiovascular contraindications. & $\begin{array}{l}\text { In the analgetic indication: } \\
\text { paracetamol, metamizole, } \\
\text { hydromorphone. }\end{array}$ & & & $\mathbf{x}$ & & \\
\hline 47 & Chlorzoxazone & M03BВ03 & & & $\mathbf{x}$ & & & & YES \\
\hline 48 & Baclofen & M03BX01 & $\begin{array}{l}\text { Common side effects: delirium, falls, } \\
\text { headache, sedation, drowsiness, amnesia. }\end{array}$ & Thiocolchicoside, mephenesine & & $\mathbf{x}$ & $\mathbf{x}$ & $\mathbf{x}$ & YES \\
\hline 49 & Pethidine & N02AB02 & $\begin{array}{l}\text { The major metabolite normeperidine can } \\
\text { cause convulsions, delirium, sedation, } \\
\text { and respiratory depression. }\end{array}$ & Hydromorphone & & & $\mathbf{x}$ & $\mathbf{x}$ & YES \\
\hline 50 & Buprenorphine & N02AE01 & $\begin{array}{l}\text { CNS side effects: sedation and delirium, } \\
\text { gastrointestinal effects: nausea at the } \\
\text { beginning and constipation with medium- } \\
\text { and long-term administration, } \\
\text { anticholinergic side effects. }\end{array}$ & Hydromorphone & & & & $\mathbf{x}$ & YES \\
\hline 51 & Tramadol & N02AX02 & $\begin{array}{l}\text { Lowers seizure threshold, may lead to } \\
\text { delirium. Frequent unwanted side effects: } \\
\text { vomiting, vertigo, constipation. }\end{array}$ & $\begin{array}{l}\text { Paracetamol, metamizole, } \\
\text { hydromorphone. }\end{array}$ & & & & $\mathbf{x}$ & YES \\
\hline
\end{tabular}




\begin{tabular}{|c|c|c|c|c|c|c|c|c|c|}
\hline & Drug & $\begin{array}{l}\text { ATC } \\
\text { code }\end{array}$ & Reasons & Alternative drugs & $\begin{array}{l}\text { Beers } \\
2015\end{array}$ & $\begin{array}{l}\text { La- } \\
\text { Roche } \\
2007\end{array}$ & $\begin{array}{l}\text { Priscuss } \\
2010\end{array}$ & $\underset{2011}{\operatorname{Mann}}$ & $\begin{array}{c}\text { Risk } \\
\text { of falls }\end{array}$ \\
\hline 52 & $\begin{array}{l}\text { Acetylsalicylic } \\
\text { acid }\end{array}$ & N02BA01 & $\begin{array}{l}\text { High rate of gastrointestinal side effects } \\
\text { (bleeding) in/with long-term use. }\end{array}$ & $\begin{array}{l}\text { In the analgetic indication: } \\
\text { paracetamol, metamizole, } \\
\text { hydromorphone. }\end{array}$ & & & & $\mathbf{x}$ & \\
\hline 53 & Ergotamine & N02CA52 & $\begin{array}{l}\text { Vasoconstriction can lead to angina } \\
\text { pectoris, hypertension, glaucoma, liver } \\
\text { and renal impairment, urinary retention } \\
\text { and cramping. Unfavorable risk/benefit } \\
\text { profile. }\end{array}$ & Therapy waiver & & & $\mathbf{x}$ & & \\
\hline 54 & Phenobarbital & N03AA02 & $\begin{array}{l}\text { Sedation, paradoxical excitation, clinical } \\
\text { monitoring for adverse effects (testing of } \\
\text { gait steadiness, coordination; } \\
\text { psychopathology). }\end{array}$ & $\begin{array}{l}\text { Other antiepeleptic drugs: } \\
\text { lamotrigine, valproic acid, } \\
\text { levetiracetam, gabapentin. }\end{array}$ & & & $\mathbf{x}$ & $\mathbf{x}$ & YES \\
\hline 55 & Phenytoin & N03AB02 & $\begin{array}{l}\text { CNS depression, including delirium, } \\
\text { tremor, ataxia, nystagmus, anaemia and } \\
\text { osteomalacia. }\end{array}$ & & & & & $\mathbf{x}$ & YES \\
\hline 56 & Clonazepam & N03AE01 & $\begin{array}{l}\text { CNS depression, including delirium, } \\
\text { depression, amnesia and ataxia. }\end{array}$ & & & & & $\mathbf{x}$ & YES \\
\hline 57 & Biperiden & N04AA02 & $\begin{array}{l}\text { Anticholinergic side effects: restlessness, } \\
\text { delirium, urinary retention and negative } \\
\text { effect on cognitive functions. }\end{array}$ & L-dopa & & $\mathbf{x}$ & & $\mathbf{x}$ & YES \\
\hline 58 & Ropinirole & N04BC04 & $\begin{array}{l}\text { Higher potential for hallucinations and } \\
\text { delirium. }\end{array}$ & & & & & $\mathbf{x}$ & \\
\hline 59 & Pramipexole & N04BC05 & $\begin{array}{l}\text { Higher potential for hallucinations and } \\
\text { delirium. }\end{array}$ & & & & & $\mathbf{x}$ & \\
\hline 60 & Rotigotine & N04BC09 & $\begin{array}{l}\text { Higher potential for hallucinations and } \\
\text { delirium. }\end{array}$ & & & & & $\mathbf{x}$ & \\
\hline 61 & $\begin{array}{l}\text { Levome- } \\
\text { promazine }\end{array}$ & N05AA02 & $\begin{array}{l}\text { Main side effects: anticholinergic } \\
\text { (urinary retention, constipation, visual } \\
\text { disturbances), cognitive impairment, } \\
\text { noradrenergic (orthostatic hypotension), } \\
\text { antihistaminergic (sedation), } \\
\text { extrapyramidal symptoms including } \\
\text { Parkinson-like symptoms, dystonia, } \\
\text { akathisia and tardive dyskinesia. }\end{array}$ & So-called atypical neuroleptics. & & $\mathbf{x}$ & $\mathbf{x}$ & $\mathbf{x}$ & YES \\
\hline
\end{tabular}




\begin{tabular}{|c|c|c|c|c|c|c|c|c|c|}
\hline & Drug & $\begin{array}{l}\text { ATC } \\
\text { code }\end{array}$ & Reasons & Alternative drugs & $\begin{array}{c}\text { Beers } \\
2015\end{array}$ & $\begin{array}{l}\text { La- } \\
\text { Roche } \\
2007\end{array}$ & $\begin{array}{l}\text { Priscuss } \\
2010\end{array}$ & $\begin{array}{c}\text { Mann } \\
2011\end{array}$ & $\begin{array}{c}\text { Risk } \\
\text { of falls }\end{array}$ \\
\hline 62 & Fluphenazine & N05AB02 & $\begin{array}{l}\text { Main side effects: anticholinergic } \\
\text { (urinary retention, constipation, visual } \\
\text { disturbances), cognitive impairment, } \\
\text { noradrenergic (orthostatic hypotension), } \\
\text { antihistaminergic (sedation), } \\
\text { extrapyramidal symptoms including } \\
\text { Parkinson-like symptoms, dystonia, } \\
\text { akathisia and tardive dyskinesia. }\end{array}$ & So-called atypical neuroleptics. & & $\mathbf{X}$ & $\mathbf{x}$ & $\mathbf{x}$ & YES \\
\hline 63 & Pipotiazine & N05AC04 & $\begin{array}{l}\text { Muscarinic-blocking drugs. Second } \\
\text { choice drugs. }\end{array}$ & $\begin{array}{l}\text { Atypical antipsychotics with less } \\
\text { anticholinergic activity (clozapine, } \\
\text { risperidone, olanzapine, amisulpride, } \\
\text { quetiapine), meprobamate. }\end{array}$ & & $\mathbf{x}$ & & & \\
\hline 64 & Haloperidol & N05AD01 & $\begin{array}{l}\text { Main side effects: anticholinergic } \\
\text { (urinary retention, constipation, visual } \\
\text { disturbances), cognitive impairment, } \\
\text { noradrenergic (orthostatic hypotension), } \\
\text { antihistaminergic (sedation), } \\
\text { extrapyramidal symptoms including } \\
\text { Parkinson-like symptoms, dystonia, } \\
\text { akathisia and tardive dyskinesia. }\end{array}$ & So-called atypical neuroleptics. & & & $\mathbf{x}$ & $\mathbf{x}$ & YES \\
\hline 65 & Clozapine & N05AH02 & Can cause agranulocytosis. & & & & $\mathbf{x}$ & $\mathbf{x}$ & \\
\hline 66 & Olanzapine & N05AH03 & $\begin{array}{l}\text { Extrapyramidal and anticholinergic side } \\
\text { effects, sedation, and cognitive } \\
\text { impairment especially with higher doses. }\end{array}$ & & & & $\mathbf{x}$ & $\mathbf{x}$ & YES \\
\hline 67 & Diazepam & N05BA01 & Prolonged reaction times. & Opipramol & $\mathbf{x}$ & $\mathbf{x}$ & $\mathbf{x}$ & $\mathbf{X}$ & YES \\
\hline 68 & $\begin{array}{l}\text { Chlor- } \\
\text { diazepoxide }\end{array}$ & N05BA02 & $\begin{array}{l}\text { Risk of falling (muscle-relaxing effect) } \\
\text { with risk of hip fracture. }\end{array}$ & $\begin{array}{l}\text { Short-(/shorter-)acting } \\
\text { benzodiazepines, zolpidem, } \\
\text { zopiclone, zaleplone at a low dose. }\end{array}$ & $\mathbf{x}$ & $\mathbf{x}$ & $\mathbf{x}$ & $\mathbf{x}$ & YES \\
\hline 69 & Medazepam & N05BA03 & Long-acting benzodiazepines & & & & $\mathbf{x}$ & & YES \\
\hline 70 & Clobazam & N05BA09 & $\begin{array}{l}\text { Long-acting benzodiazepines, protracted } \\
\text { activity, increased likelihood of adverse } \\
\text { effects occurrence (drowsiness, falls). }\end{array}$ & & & $\mathbf{x}$ & $\mathbf{X}$ & & YES \\
\hline 71 & Alprazolam & N05BA12 & Long-acting benzodiazepines & & $\mathbf{x}$ & $\mathbf{x}$ & $\mathbf{X}$ & & YES \\
\hline
\end{tabular}




\begin{tabular}{|c|c|c|c|c|c|c|c|c|c|}
\hline & Drug & $\begin{array}{l}\text { ATC } \\
\text { code }\end{array}$ & Reasons & Alternative drugs & $\begin{array}{l}\text { Beers } \\
2015\end{array}$ & $\begin{array}{c}\text { La- } \\
\text { Roche } \\
\mathbf{2 0 0 7}\end{array}$ & $\begin{array}{l}\text { Priscuss } \\
2010\end{array}$ & $\begin{array}{c}\text { Mann } \\
2011\end{array}$ & $\begin{array}{l}\text { Risk } \\
\text { of falls }\end{array}$ \\
\hline 72 & Meprobamate & N05BC01 & Long-acting benzodiazepines & & $\mathbf{x}$ & $\mathbf{x}$ & & & YES \\
\hline 73 & Nitrazepam & N05CD02 & $\begin{array}{l}\text { Long-acting benzodiazepines, protracted } \\
\text { activity, increased likelihood of adverse } \\
\text { effects occurrence (drowsiness, fall). }\end{array}$ & & & $\mathbf{x}$ & $\mathbf{x}$ & $\mathbf{x}$ & YES \\
\hline 74 & Temazepam & N05CD07 & Long-acting benzodiazepines & & $\mathbf{x}$ & $\mathbf{x}$ & $\mathbf{x}$ & & \\
\hline 75 & Brotizolam & N05CD09 & $\begin{array}{l}\text { Short- and intermediate acting } \\
\text { benzodiazepines }(>0.125 \mathrm{mg} / \text { day }) .\end{array}$ & & & & $\mathbf{x}$ & $\mathbf{X}$ & \\
\hline 76 & Zopiclone & N05CF01 & Delayed reaction time (>3.75 mg/day). & & & $\mathbf{x}$ & $\mathbf{x}$ & & YES \\
\hline 77 & Zolpidem & N05CF02 & $\begin{array}{l}\text { Risk of falling and hip fracture } \\
(>5 \mathrm{mg} / \mathrm{d}) \text {. }\end{array}$ & $\begin{array}{l}\text { Combining form: short- and } \\
\text { intermediate-acting benzodiazepines. }\end{array}$ & & $\mathbf{x}$ & $\mathbf{x}$ & & YES \\
\hline 78 & Zaleplone & N05CF03 & $\begin{array}{l}\text { Psychiatric reactions (sometimes } \\
\text { paradoxical, e.g., agitation, irritability, } \\
\text { hallucinations, psychosis), cognitive } \\
\text { impairment (>5 mg/d). }\end{array}$ & & & & $\mathbf{x}$ & & YES \\
\hline 79 & Imipramine & N06AA02 & $\begin{array}{l}\text { Drowsiness, inner unrest, confusion, } \\
\text { muscarinic-blocking agents with } \\
\text { cardiotoxicity when overdosed. }\end{array}$ & $\begin{array}{l}\text { Non-pharmacological treatments } \\
\text { such as behavioral therapy. }\end{array}$ & $\mathbf{X}$ & $\mathbf{x}$ & $\mathbf{x}$ & & YES \\
\hline 80 & Clomipramine & N06AA04 & $\begin{array}{l}\text { Muscarinic-blocking agents with } \\
\text { cardiotoxicity when overdosed. }\end{array}$ & & & $\mathbf{x}$ & $\mathbf{x}$ & $\mathbf{x}$ & YES \\
\hline 81 & Trimipramine & N06AA06 & $\begin{array}{l}\text { Muscarinic-blocking agents with } \\
\text { cardiotoxicity when overdosed. }\end{array}$ & & & $\mathbf{X}$ & $\mathbf{X}$ & & YES \\
\hline 82 & Amitriptyline & N06AA09 & $\begin{array}{l}\text { Muscarinic-blocking agents with } \\
\text { cardiotoxicity when overdosed. }\end{array}$ & & $\mathbf{x}$ & $\mathbf{X}$ & $\mathbf{x}$ & $\mathbf{X}$ & YES \\
\hline 83 & Maprotiline & N06AA21 & $\begin{array}{l}\text { Muscarinic-blocking agents with } \\
\text { cardiotoxicity when overdosed. }\end{array}$ & & & $\mathbf{x}$ & $\mathbf{X}$ & $\mathbf{X}$ & YES \\
\hline 84 & Fluoxetine & N06AB03 & $\begin{array}{l}\text { Common side effects: headache, } \\
\text { insomnia, drowsiness, ataxia, tremor, } \\
\text { convulsions. }\end{array}$ & & $\mathbf{x}$ & & $\mathbf{x}$ & & YES \\
\hline 85 & Fluvoxamine & N06AB08 & $\begin{array}{l}\text { Nausea, vomiting, drowsiness, dizziness, } \\
\text { dry mouth, constipation, diarrhoea, } \\
\text { weight loss/anorexia. }\end{array}$ & Other SSRIs; SNRIs; mirtazapine. & & & & $\mathbf{x}$ & YES \\
\hline 86 & Piracetam & N06BX03 & $\begin{array}{l}\text { Increased risk of orthostatic hypotension } \\
\text { and falls and/or efficacy not proven. }\end{array}$ & Therapy waiver & & $\mathbf{x}$ & $\mathbf{x}$ & $\mathbf{x}$ & YES \\
\hline
\end{tabular}




\begin{tabular}{|c|c|c|c|c|c|c|c|c|c|}
\hline & Drug & $\begin{array}{l}\text { ATC } \\
\text { code }\end{array}$ & Reasons & Alternative drugs & $\begin{array}{l}\text { Beers } \\
2015\end{array}$ & $\begin{array}{l}\text { La- } \\
\text { Roche } \\
2007\end{array}$ & $\begin{array}{l}\text { Priscuss } \\
2010\end{array}$ & $\begin{array}{c}\text { Mann } \\
2011\end{array}$ & $\begin{array}{c}\text { Risk } \\
\text { of falls }\end{array}$ \\
\hline 87 & Ginkgo Biloba & N06DX02 & $\begin{array}{l}\text { No proven efficacy, high risk of postural } \\
\text { hypotension and falls. }\end{array}$ & & & $\mathbf{x}$ & & $\mathbf{x}$ & YES \\
\hline 88 & Hydroxyzine & N07XX04 & $\begin{array}{l}\text { Can cause delirium and anticholinergic } \\
\text { side effects like dry mouth, urinary } \\
\text { retention, and constipation, and can cause } \\
\text { QT interval prolongation. }\end{array}$ & & $\mathbf{x}$ & $\mathbf{x}$ & $\mathbf{x}$ & $\mathbf{x}$ & YES \\
\hline 89 & Theophylline & R03DA04 & $\begin{array}{l}\text { Can cause atrial fibrillation and atrial } \\
\text { flutter and tachycardia, cardiac } \\
\text { arrhythmia, seizures, insomnia and } \\
\text { irritability, vomiting and diarrhoea; dose- } \\
\text { dependent. }\end{array}$ & $\begin{array}{l}\text { Inhalational drugs including } \\
\text { tiotropium, glucocorticoids and long- } \\
\text { acting beta-sympathomimetic drugs. }\end{array}$ & & & & $\mathbf{x}$ & \\
\hline 90 & $\begin{array}{l}\text { Diphen- } \\
\text { hydramine }\end{array}$ & R06AA02 & $\begin{array}{l}\text { Anticholinergic effects, dizziness, ECG } \\
\text { changes. }\end{array}$ & $\begin{array}{l}\text { Monitor for anticholinergic side } \\
\text { effects, ECG. }\end{array}$ & $\mathbf{x}$ & $\mathbf{x}$ & $\mathbf{x}$ & & YES \\
\hline 91 & Dimetindene & R06AB03 & ECG changes (prolonged QT). & & & & $\mathbf{x}$ & & \\
\hline 92 & Promethazine & R06AD02 & $\begin{array}{l}\text { Other drugs with anticholinergic } \\
\text { properties. No proven efficacy. } \\
\text { Muscarinic-blocking agents, can cause } \\
\text { confusion, sedation. }\end{array}$ & $\begin{array}{l}\text { Nausea: domperidone. Cough: } \\
\text { clobutinol, olexadine. Drowsiness: } \\
\text { acetyl-leucine, betahistine. Rhinitis: } \\
\text { saline. }\end{array}$ & $\mathbf{x}$ & $\mathbf{x}$ & & & \\
\hline 93 & $\begin{array}{l}\text { Cypro- } \\
\text { heptadine }\end{array}$ & R06AX02 & $\begin{array}{l}\text { Muscarinic-blocking drugs, can cause } \\
\text { sedation, drowsiness. }\end{array}$ & Cetirizine, desloratadine, loratadine. & $\mathbf{x}$ & $\mathbf{x}$ & & & \\
\hline 94 & Clonidine & S01EA04 & $\begin{array}{l}\text { The aged are more sensitive to sedation, } \\
\text { hypotension, bradycardia, syncope. }\end{array}$ & $\begin{array}{l}\text { Other antihypertensive drugs, except } \\
\text { short-acting calcium-channel } \\
\text { blockers and reserpine. }\end{array}$ & $\mathbf{x}$ & $\mathbf{x}$ & & $\mathbf{x}$ & YES \\
\hline
\end{tabular}


ANNEX 
]$_{0}$ 


\title{
Gender inequalities in the treatment of osteoporosis
}

\author{
Andrea Bor*, Mária Matuz, Nóra Gyimesi, Zsuzsanna Biczók, Gyöngyvér Soós, Péter Doró \\ University of Szeged, Faculty of Pharmacy, Department of Clinical Pharmacy, Szikra utca 8, 6725 Szeged, Hungary
}

\section{A R T I C L E I N F O}

\section{Article history:}

Received 11 July 2014

Received in revised form 27 October 2014

Accepted 3 November 2014

\section{Keywords:}

Osteoporosis

Sex-specific differences

Drug utilization

Bisphosphonates

Hip fracture

\begin{abstract}
A B S T R A C T
Introduction: Our aim was to perform both gender- and age-specific analysis regarding the utilisation of anti-osteoporotic drugs in Hungary, between 2007 and 2011, and to compare our results with other European countries.

Methods: The database of the Hungarian National Health Insurance Fund was screened for antiosteoporotic medications, covering $100 \%$ of the Hungarian population (10 million people). ICD coding system (International Classification of Diseases) and WHO ATC/DDD methodology were used for medication screening and analysis.

Results: In Hungary, the total bisphosphonate use was 6.66DDD/TID (Defined Daily Dose/ 1000 inhabitants/day) in 2007, and 6.22 DDD/TID in 2011; the rate of bisphosphonate combinations slightly increased from 1.60 to $2.81 \mathrm{DDD} / \mathrm{TID}$. The total vitamin $\mathrm{D}$ use almost doubled (13.73 DDD/TID in 2011), while the calcium supplementation tripled (4.47 DDD/TID in 2011), and so did the strontium ranelate utilisation (0.70 DDD/TID in 2011) within the investigated time period. Denosumab consumption was marginal. Male patients were disproportionately, 10-20 times undertreated in all age groups, and treatment choice was restricted among men. Several differences were seen in our results compared to those in Baltic countries, Finland and in Norway.

Conclusions: Men were significantly undertreated in all age groups, compared to women. The 10 to 20 -fold difference calls attention to this unrecognised problem.
\end{abstract}

C 2014 Elsevier Ireland Ltd. All rights reserved.

\section{Introduction}

Osteoporosis is a metabolic bone disease, characterised by decreased bone mass, quality and strength, and increased susceptibility to fracture, even to minimal trauma [1]. The incidence of osteoporosis is increasing with age, occurring mainly above the age of 50 years. Osteoporosis is mostly defined as the disease of women, because the prevalence and fracture rates are much higher among females. However, the disease affects a significant portion of men, as well. From the 10 million residents of Hungary, it is estimated that in the population over 50 years of age 547,107 people suffered from osteoporosis, of which 94,949 were male and 452,158 were females in the year of 2010 [2]. Similar prevalence rates were found in every country in the European Union [2]. At the same time, according to the National Osteoporosis Foundation, the rate was higher in the USA [3]. Bone fractures are important factors of high mortality and morbidity rates in osteoporotic patients. As hip fractures require urgent surgical intervention, hospitalisation and

\footnotetext{
* Corresponding author. Tel.: +36 6234 2506; fax: +36 62544921.

E-mail address: andrea.bor@pharm.u-szeged.hu (A. Bor).
}

prolonged rehabilitation, these fractures are the most significant consequences of osteoporosis. Therefore, treatment costs of hip fractures are substantial, and osteoporosis-induced costs are a huge financial burden for the health care system and for the patients as well, besides extreme pain and high mortality rates.

Among patients with hip fractures the female/male ratio is $70: 30$, though the mortality rate is much higher in men than in women: $31 \%$ vs $17 \%$, within one year after fracture [4-7]. There are approximately 100,000 osteoporotic bone fractures each year in Hungary, and the treatment costs are estimated to be more than 20 billion HUF (Hungarian Forints, about 64.5 million EUR) for the National Health Insurance Fund (NHIF). At the same time, the expenses of prevention and pharmacological treatment take only 8 billion HUF ( 26 million EUR), moreover, $50 \%$ of osteoporotic fractures would be preventable with appropriate pharmacological treatment and with screening the population at risk [8].

Our aim was (1) to perform gender- and age-specific analysis regarding the utilisation of anti-osteoporotic drugs in Hungary, covering a 5-year period (between 2007 and 2011), (2) to analyse the differences of treatment characteristics between males and females, and (3) to compare our results with those in other European countries. 


\section{Methods}

\subsection{Data source}

The source of our crude data was the Hungarian National Health Insurance Fund, which is the sole, mandatory, national health insurance fund, covering $100 \%$ of the Hungarian population (roughly 10 million people). All prescription claims are recorded by the providers; the NHIF database contains data on age, gender, residence, date of claim, medication, and diagnosis by ICD codes (International Classification of Diseases, 2010).

For our study the NHIF provided anonymous, aggregated crude data; therefore, the study did not require ethical approval.

\subsection{Database screening for anti-osteoporotic medications}

A retrospective analysis was performed regarding antiosteoporotic medication use in Hungary, for the period between 2007 and 2011. The following details on medication use were available in the crude data: calendar year (2007-2011), gender, age group (in 5-year-long clusters), ATC code (Anatomical Therapeutic Chemical Classification), active pharmaceutical ingredient, product name, strength, ICD code (first 3 digits), number of packaging units, number of patients, and total number of DDDs (Defined Daily Dose)

Microsoft Access and Microsoft Excel programs were used for data management and analysis.

The primary screening method was based on the ATC codes (2013 version) of drugs [9].

The screened drugs that are available for the treatment of osteoporosis in Hungary were the followings: vitamin D and analogues (ATC: A11CC02-05), calcium compounds (A12AA03-04, and A12AA13), bisphosphonates (M05BA02-08), bisphosphonate combinations (M05BB03-04), strontium ranelate (M05BX03), and denosumab (M05BD01)

The DDD is the average maintenance daily dose of the medication used for its main therapeutic indication in adults [10]. The medication use of large populations is often expressed as the number of DDDs per 1000 inhabitants per day, which technical unit enables to compare the drug use of populations of different sizes [11].

To obtain standardised, DDD/1000 inhabitants/day (DDD/TID) unit, we calculated with the formula below:

$\mathrm{DDD} / \mathrm{TID}=\frac{\mathrm{DDD} / 365}{\text { population size } \times 1000}$.

For each year, the gender and age-standardised data on population size were gained from the Hungarian Central Statistical Office (HCSO) [12]. The youngest population receiving anti-osteoporotic treatment was the 40 to 44 -year-old group (Table 2). In 2007 the total Hungarian population was $10,055,783$ inhabitants, out of which there were $4,928,988$ people above the age of 40 years $(2,158,031$ males and 2,770,967 females), while in 2011 the total population was $9,971,727$ inhabitants, out of which $5,010,276$ people were above the age of 40 years $(2,201,817$ males and $2,808,459$ females) [12].

The secondary screening method was based on the indications of drugs, coded by ICD (included ICDs: E55-58, M80, M81).

\subsection{Further technical assumptions}

a. In the case of bisphosphonate combinations (alendronic acid+vitamin D, M05BB03, alendronic acid+vitamin $\mathrm{D}+$ calcium, M05BB05, risedronic acid + vitamin D+calcium, M05BB04) different vitamin D and calcium doses were found from those in the vitamin D and calcium monotherapy medications. Therefore, direct comparison on each vitamin D,

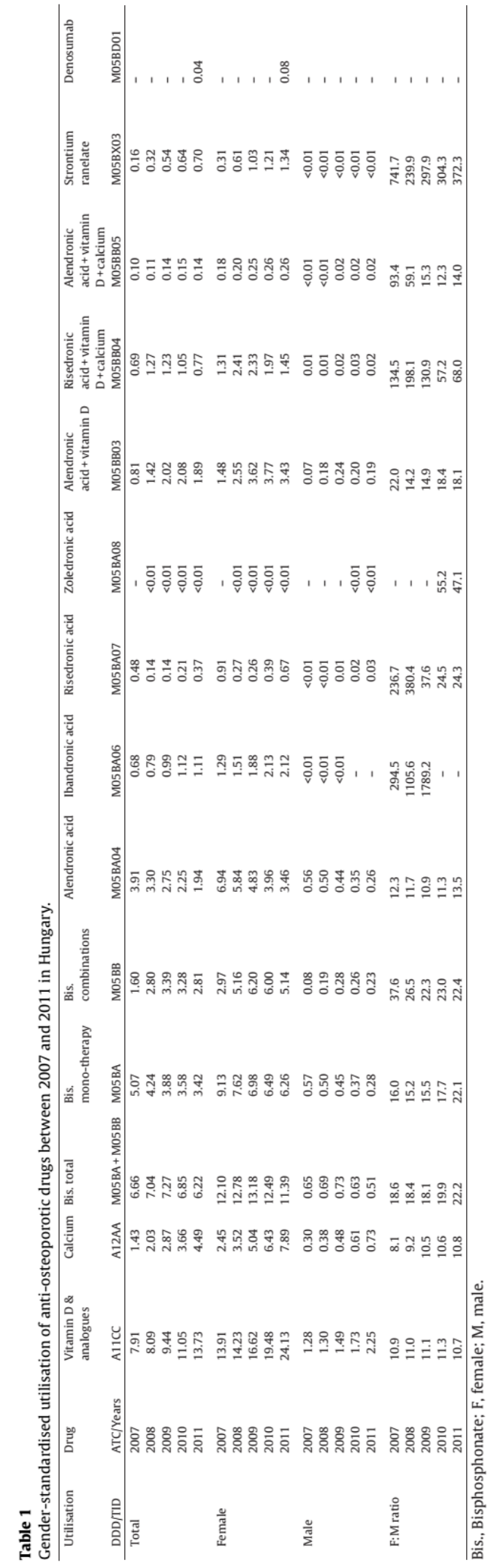


and calcium-containing medications was not possible, since $\mathrm{DDD} / \mathrm{TID}$ values were also different in the combinations. These categories are presented separately.

b. To avoid any bias, drugs for the treatment of malignancies (ICD "C" group and M82, M85) were excluded from the final analysis. The rate of excluded drugs (expressed in DDD \%) in the indication of cancer therapy was the following: vitamin D and analogues $1.38 \%$, calcium compounds $2.64 \%$, bisphosphonates $8.34 \%$, bisphosphonate combinations $0.12 \%$, denosumab and strontium ranelate less than $0.1 \%$, all of which was roughly $3 \%$ of treated patients.

\section{Results}

\subsection{Gender and population-based results}

As expected, medication use by females was substantially higher in the case of every medication than by males (Table 1 ).

During the examined 5-year period, the utilisation of vitamin $\mathrm{D}$ and analogues showed constant increase from 7.91 DDD/TID to $13.73 \mathrm{DDD} / \mathrm{TID}$. A similar tendency was revealed in female and male patients. However, there was an approximately $10-$ fold difference between genders, male patients were remarkably undertreated (Fig. 1). Vitamin D can also be found in combination with bisphosphonates, therefore the overall consumption was higher.

The utilisation of calcium compounds increased from 1.43 DDD/TID in 2007 to $4.49 \mathrm{DDD} / \mathrm{TID}$ in 2011, which is a more than three-fold growth. This tendency mainly arose from the treatment of female patients; males are significantly undertreated (F:M ratio was 10.8 in 2011). As calcium occurs in combination with alendronic and risedronic acid, the total rate would be higher than above.

The total bisphosphonate use was 6.66 DDD/TID in 2007, it slowly increased in 2008 and 2009, but for 2011 it dropped to 6.22 DDD/TID. Male patients were treated approximately 20 times less than women (F:M ratio was 22.2 in 2011). In 2007, monotherapy took roughly $75 \%$ of the total trade compared to $55 \%$ in 2011 since the use of bisphosphonate combinations gradually increased, and nearly reached the rate of monotherapy in females and in males as well (Fig. 2).

The most widely used agent was alendronic acid; however, during the 5-year-long period, the trade of alendronic acid in monotherapy halved (3.91 vs $1.94 \mathrm{DDD} / \mathrm{TID}$ ), while the combination with vitamin D more than doubled ( 0.81 vs $1.89 \mathrm{DDD} / \mathrm{TID}$ ). The trade of vitamin $\mathrm{D}$ and calcium combination with alendronic acid was 0.15 DDD/TID in 2011. Alendronic acid took almost two-third of the total bisphosphonate use in all investigated years.

The use of risedronic acid was more or less constant. The rate of combination with vitamin D and calcium was double compared to monotherapy (0.37 vs $0.77 \mathrm{DDD} / \mathrm{TID}$ in 2011). It accounted for roughly one-fifth of all bisphosphonate trade in all years.

Ibandronic acid took around 16\% (1.11 DDD/TID in 2011) of the total bisphosphonate consumption, and it was prescribed only for women; in 2010 and in 2011 there was no use of it in the male population.

Zoledronic acid use has remained marginal since 2007 on the Hungarian market with less than 0.01 DDD/TID.

Strontium ranelate is mainly prescribed for women after the bisphosphonate therapy failed or could not be tolerated. The trade showed a constant increase since 2007 (0.16 DD/TID), for 2011 it reached $0.70 \mathrm{DDD} / \mathrm{TID}$.

Denosumab, a monoclonal antibody, was introduced to the Hungarian market in 2011 and took 0.04 DDD/TID in that year.

\subsection{Gender- and age-standardised results (Table 2)}

The utilisation of bisphosphonates was the highest in the 75 to 79-year-old population in both genders, but with very different values: $49.27 \mathrm{DDD} / 1000 \mathrm{females} /$ day and $3.40 \mathrm{DDD} / 1000$ males/day in 2011. The highest decrease in bisphosphonate utilisation was detected in the 40-54 age groups in both genders during the study period. The largest differences between genders could be seen in 2011 in all age groups.

Strontium ranelate was prescribed to male patients only above the age of 60 , but less than $0.05 \mathrm{DDD} / 1000 \mathrm{males} /$ day. In women, a remarkable rise can be seen in all age groups from 2007 to 2011.

The trade of denosumab in females peaked in the 70 to 74 -yearold population ( $0.37 \mathrm{DDD} / 1000$ females/day) in 2011. There was no denosumab use among male patients.

\subsection{Comparison with European countries}

Comparable DDD/TID values of anti-osteoporotic medications use were available from 2008 in Estonia, from 2009 in Finland, from 2010 in Latvia and Lithuania, and from 2007 in Norway; however, published age- and gender-matched data have not been found for the same time period [13-16]. The comparison is presented in Table 3, all values refer to the total population of each country.

Results on total bisphosphonate use differ in all investigated countries. The declining tendency and the utilisation rate were similar in Finland, in Norway, and in Hungary. In contrast, Estonian, Latvian and Lithuanian bisphosphonate use was about 2-3 times lower, but a slowly increasing tendency or constant rate (Lithuania) was present in all three Baltic countries.

In Finland and in Hungary, alendronic acid monotherapy took the majority of the bisphosphonate trade, similarly to Norway, while in the Baltic countries the use of bisphosphonate agents was more various.

Regarding bisphosphonate combinations, the use of alendronic acid and vitamin D combination was more or less constant in Latvia, Lithuania and in Hungary. In Finland, a certain decline was seen between 2009 and 2011, while the Estonian data on alendronic acid combination markedly increased, from 0.93 DDD/TID in 2008 to $2.52 \mathrm{DDD} / \mathrm{TID}$ in 2011. No use of bisphosphonate combinations was noticed in Norway.

Strontium ranelate consumption was the highest in Hungary in 2010 and in 2011, similarly high in Lithuania, with an approximately 5 to 10 -fold difference between Estonia, but the tendency of use was increasing in all countries, except in Norway (strontium ranelate is not available).

Denosumab utilisation was the highest in Finland in 2011 (0.37 DDD/TID).

\section{Discussion}

A retrospective gender- and age-specific drug utilisation analysis was performed of medications indicated for the treatment of osteoporosis between 2007 and 2011 in Hungary.

As expected, men were disproportionately undertreated in all age groups compared to women, and treatment choice was restricted for vitamin $\mathrm{D}$, calcium supplementation and bisphosphonates compared to women. The persistent 10 to 20 -fold difference between males and females does not reflect the estimated 1:5 proportion of males and females affected by osteoporosis in Hungary. In a similar age and gender-standardised Australian study, a much milder 3 to 4 -fold gender difference was found between the use of alendronic acid and risedronic acid in 2005-2006 [17]. Recently, results of numerous randomised controlled trials have confirmed that anti-osteoporosis drugs are equally effective in 
Table 2

Gender- and age-standardised utilisation of specific anti-osteoporotic drugs between 2007 and 2011 in Hungary.

\begin{tabular}{|c|c|c|c|c|c|c|c|c|c|c|c|}
\hline & Calendar year & $40-44$ years & $45-49$ years & $50-54$ years & $55-59$ years & $60-64$ years & $65-69$ years & $70-74$ years & $75-79$ years & $80-84$ years & 85 and over \\
\hline \multicolumn{12}{|c|}{ Females (DDD/1000females/day) } \\
\hline \multirow{6}{*}{$\begin{array}{l}\text { Bisphosphonates } \\
\text { (M05B) }\end{array}$} & 2007 & 0.10 & 1.40 & 8.18 & 18.82 & 30.77 & 43.36 & 49.93 & 48.26 & 36.18 & 15.33 \\
\hline & 2008 & 0.05 & 1.22 & 8.05 & 18.72 & 31.37 & 44.92 & 52.58 & 53.38 & 39.94 & 17.02 \\
\hline & 2009 & 0.06 & 1.07 & 8.31 & 18.92 & 31.36 & 44.89 & 53.15 & 54.92 & 43.25 & 19.39 \\
\hline & 2010 & 0.05 & 0.72 & 7.17 & 17.79 & 28.54 & 41.14 & 49.72 & 53.24 & 42.93 & 19.44 \\
\hline & 2011 & 0.04 & 0.53 & 5.56 & 15.78 & 25.67 & 36.58 & 44.79 & 49.27 & 41.04 & 18.62 \\
\hline & $\begin{array}{l}\text { \% change } \\
2007-2011\end{array}$ & $-59.6 \%$ & $-62.0 \%$ & $-32.1 \%$ & $-16.1 \%$ & $-16.6 \%$ & $-15.6 \%$ & $-10.3 \%$ & $2.1 \%$ & $13.4 \%$ & $21.4 \%$ \\
\hline \multirow{6}{*}{$\begin{array}{l}\text { Strontium } \\
\text { ranelate } \\
\text { (M05BX03) }\end{array}$} & 2007 & - & 0.01 & 0.12 & 0.40 & 0.66 & 1.06 & 1.42 & 1.44 & 1.22 & 0.45 \\
\hline & 2008 & - & 0.05 & 0.32 & 0.81 & 1.36 & 2.09 & 2.53 & 2.68 & 2.22 & 0.98 \\
\hline & 2009 & - & 0.07 & 0.54 & 1.39 & 2.32 & 3.58 & 4.20 & 4.32 & 3.65 & 1.76 \\
\hline & 2010 & - & 0.05 & 0.55 & 1.55 & 2.74 & 4.09 & 4.92 & 5.19 & 4.48 & 2.04 \\
\hline & 2011 & - & 0.04 & 0.52 & 1.64 & 2.95 & 4.31 & 5.33 & 5.85 & 5.20 & 2.72 \\
\hline & $\begin{array}{l}\text { \% change } \\
\text { 2007-2011 }\end{array}$ & - & $523.6 \%$ & $333.1 \%$ & $307.8 \%$ & $346.3 \%$ & $306.8 \%$ & $274.9 \%$ & $306.5 \%$ & $327.1 \%$ & $505.1 \%$ \\
\hline $\begin{array}{l}\text { Denosumab } \\
\text { (M05BD01) }\end{array}$ & 2011 & - & - & 0.08 & 0.12 & 0.23 & 0.24 & 0.37 & 0.30 & 0.12 & - \\
\hline \multicolumn{12}{|c|}{ Males (DDD/1000males/day) } \\
\hline \multirow{6}{*}{$\begin{array}{l}\text { Bisphosphonates } \\
\text { (M05B) }\end{array}$} & 2007 & 0.01 & 0.09 & 0.67 & 1.25 & 1.96 & 2.87 & 3.56 & 4.20 & 3.20 & 1.50 \\
\hline & 2008 & - & 0.12 & 0.67 & 1.29 & 2.03 & 3.10 & 3.75 & 4.51 & 3.73 & 1.53 \\
\hline & 2009 & 0.01 & 0.05 & 0.56 & 1.33 & 2.26 & 3.27 & 4.01 & 4.79 & 3.61 & 1.63 \\
\hline & 2010 & - & 0.06 & 0.36 & 1.12 & 1.78 & 2.95 & 3.45 & 3.88 & 3.58 & 1.71 \\
\hline & 2011 & - & 0.01 & 0.16 & 0.80 & 1.44 & 2.30 & 2.96 & 3.40 & 3.43 & 1.56 \\
\hline & $\begin{array}{l}\text { \%change } \\
\text { 2007-2011 }\end{array}$ & - & $-85.5 \%$ & $-76.7 \%$ & $-35.7 \%$ & $-26.6 \%$ & $-19.7 \%$ & $-16.8 \%$ & $-19.0 \%$ & $7.1 \%$ & $4.2 \%$ \\
\hline \multirow{6}{*}{$\begin{array}{l}\text { Strontium } \\
\text { ranelate } \\
\text { (M05BX03) }\end{array}$} & 2007 & - & - & - & - & - & - & 0.01 & - & - & - \\
\hline & 2008 & - & - & - & - & - & 0.02 & 0.03 & 0.01 & 0.03 & - \\
\hline & 2009 & - & - & - & - & - & 0.02 & 0.04 & 0.04 & 0.02 & - \\
\hline & 2010 & - & - & - & - & 0.01 & 0.03 & 0.02 & 0.05 & - & 0.04 \\
\hline & 2011 & - & - & - & - & 0.01 & 0.02 & 0.03 & 0.01 & 0.05 & 0.03 \\
\hline & $\begin{array}{l}\% \text { change first } \\
\text { trade year }-2011\end{array}$ & - & - & - & - & - & $5.5 \%$ & $122.4 \%$ & $-29.1 \%$ & $68.2 \%$ & $-21.6 \%$ \\
\hline $\begin{array}{l}\text { Denosumab } \\
\text { (M05BD01) }\end{array}$ & 2007-2011 & - & - & - & - & - & - & - & - & - & - \\
\hline
\end{tabular}


Table 3

Comparison on anti-osteoporotic medication use in six European countries.

\begin{tabular}{|c|c|c|c|c|c|c|c|c|c|c|c|c|c|}
\hline DDD/TID & ATC/Years & M05BA+ M05BB & $\begin{array}{l}\text { Bis. mono- } \\
\text { therapy } \\
\text { M05BA }\end{array}$ & $\begin{array}{l}\text { Bis. combi- } \\
\text { nations } \\
\text { M05BB }\end{array}$ & $\begin{array}{l}\begin{array}{l}\text { Alendronic } \\
\text { acid }\end{array} \\
\text { M05BA04 }\end{array}$ & $\begin{array}{l}\text { Ibandronic } \\
\text { acid } \\
\text { M05BA06 }\end{array}$ & $\begin{array}{l}\text { Risedronic } \\
\text { acid } \\
\text { M05BA07 }\end{array}$ & $\begin{array}{l}\begin{array}{l}\text { Zoledronic } \\
\text { acid }\end{array} \\
\text { M05BA08 }\end{array}$ & $\begin{array}{l}\text { Alendronic } \\
\text { acid + vitamin } \\
\text { D } \\
\text { M05Bв03 }\end{array}$ & $\begin{array}{l}\text { Risedronic } \\
\text { acid + vitamin } \\
\text { D+ calcium } \\
\text { M05BB04 }\end{array}$ & $\begin{array}{l}\text { Alendronic } \\
\text { acid + vitamin } \\
\text { D+calcium } \\
\text { M05BB05 }\end{array}$ & $\begin{array}{l}\text { Strontium } \\
\text { ranelate } \\
\\
\text { M05BX03 }\end{array}$ & Denosumab \\
\hline \multirow{4}{*}{ Estonia } & 2008 & 3.34 & 2.41 & 0.93 & 1.17 & 0.79 & 0.44 & - & 0.93 & - & - & 0.04 & - \\
\hline & 2009 & 3.86 & 2.09 & 1.77 & 0.78 & 0.86 & 0.44 & - & 1.77 & - & - & 0.04 & - \\
\hline & 2010 & 4.52 & 2.10 & 2.42 & 0.65 & 0.93 & 0.52 & - & 2.42 & - & - & 0.06 & - \\
\hline & 2011 & 4.38 & 1.86 & 2.52 & 0.56 & 0.8 & 0.49 & - & 2.52 & - & - & 0.09 & 0.01 \\
\hline \multirow[t]{2}{*}{ Latvia } & 2010 & 3.74 & 2.55 & 1.19 & $<0.01$ & 0.96 & 1.59 & - & 1.19 & - & - & 0.42 & $<0.01$ \\
\hline & 2011 & 4.75 & 2.93 & 1.82 & 0.01 & 0.92 & 2.00 & - & 1.82 & - & - & 0.47 & 0.02 \\
\hline \multirow{2}{*}{ Lithuania } & 2010 & 2.75 & 1.81 & 0.94 & 0.40 & 0.73 & 0.68 & - & 0.48 & 0.46 & - & 0.64 & $<0.01$ \\
\hline & 2011 & 2.66 & 1.71 & 0.95 & 0.37 & 0.73 & 0.61 & - & 0.45 & 0.50 & - & 0.53 & 0.07 \\
\hline \multirow[t]{3}{*}{ Finland } & 2009 & 10.8 & 8.34 & 2.46 & 3.84 & 1.95 & 2.54 & 0.01 & 2.46 & - & - & 0.07 & - \\
\hline & 2010 & 8.89 & 7.02 & 1.87 & 3.08 & 1.83 & 2.10 & 0.01 & 1.87 & - & - & 0.14 & 0.02 \\
\hline & 2011 & 7.97 & 6.52 & 1.45 & 2.97 & 1.73 & 1.81 & 0.01 & 1.45 & - & - & 0.32 & 0.37 \\
\hline \multirow[t]{5}{*}{ Norway } & 2007 & 9.32 & 9.32 & - & 8.86 & 0.19 & 0.27 & $<0.01$ & - & - & - & - & - \\
\hline & 2008 & 9.32 & 9.32 & - & 8.94 & 0.16 & 0.22 & $<0.01$ & - & - & - & - & - \\
\hline & 2009 & 9.05 & 9.05 & - & 8.71 & 0.15 & 0.19 & $<0.01$ & - & - & - & - & - \\
\hline & 2010 & 9.00 & 9.00 & - & 8.71 & 0.12 & 0.17 & $<0.01$ & - & - & - & - & $<0.01$ \\
\hline & 2011 & 8.81 & 8.81 & - & 8.56 & 0.10 & 0.15 & $<0.01$ & - & - & - & - & 0.07 \\
\hline \multirow[t]{3}{*}{ Hungary } & 2007 & 6.66 & 5.07 & 1.60 & 3.91 & 0.68 & 0.48 & - & 0.91 & 0.69 & 0.10 & 0.16 & - \\
\hline & 2008 & 7.04 & 4.24 & 2.80 & 3.30 & 0.79 & 0.14 & $<0.01$ & 1.42 & 1.27 & 0.11 & 0.32 & - \\
\hline & 2009 & 7.27 & 3.88 & 3.39 & 2.75 & 0.99 & 0.14 & $<0.01$ & 2.02 & 1.23 & 0.14 & 0.54 & - \\
\hline
\end{tabular}




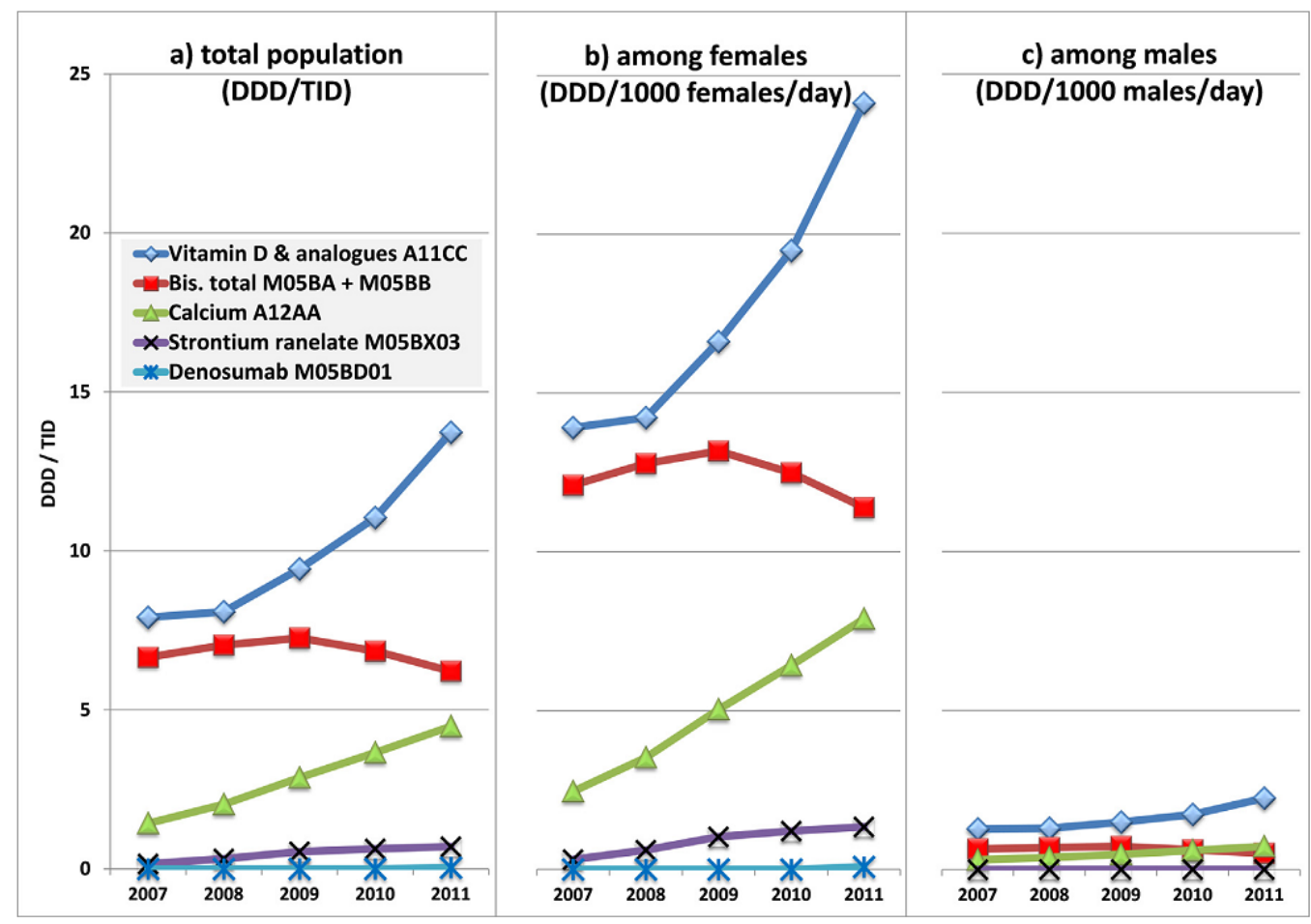

Fig. 1. Utilisation of anti-osteoporotic medications in Hungary 2007-2011.

males and females [18-21]. Based on those findings, the recommended treatment options for male patients are calcium and vitamin $\mathrm{D}$ supplementation as first line treatment, and in combination with alendronate, risedronate, zoledronate, denosumab and teriparatide. All of these drugs are available in Hungary, however, in practice, besides health professional considerations, drug choice is also determined by the costs and reimbursement criteria.

Investigating the Hungarian incidence of hip fractures in 2007 and 2011 (Fig. 3) would probably provide a better understanding of the importance of osteoporosis treatment. According to the "Tables of basic data on Hungarian health care", the highest incidence of osteoporotic hip fractures was 3332.8 per 100,000 females aged 85 above, and 2151.2 per 100,000 males for the same age group in 2011 [22]. Hip fractures were identified according to ICD codes (S72.0, S72.1, and S72.2).

An exponentially growing tendency with age can be seen in the incidence of osteoporotic hip fractures in both investigated years. The incidence between 2007 and 2011 was more or less constant, showing slightly elevating tendency above the age of 75 years in both genders. However, a remarkable $8.7 \%$ increase in absolute

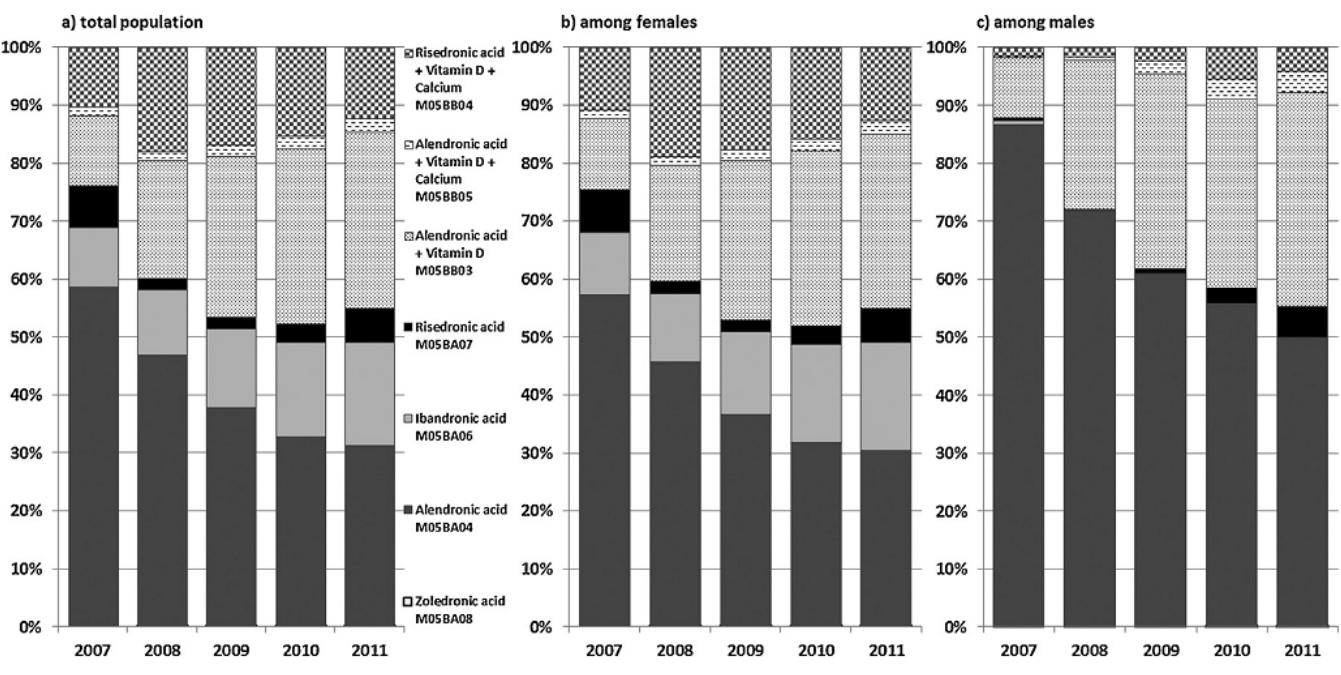

Fig. 2. Utilisation rate of bisphosphonates in Hungary 2007-2011. 


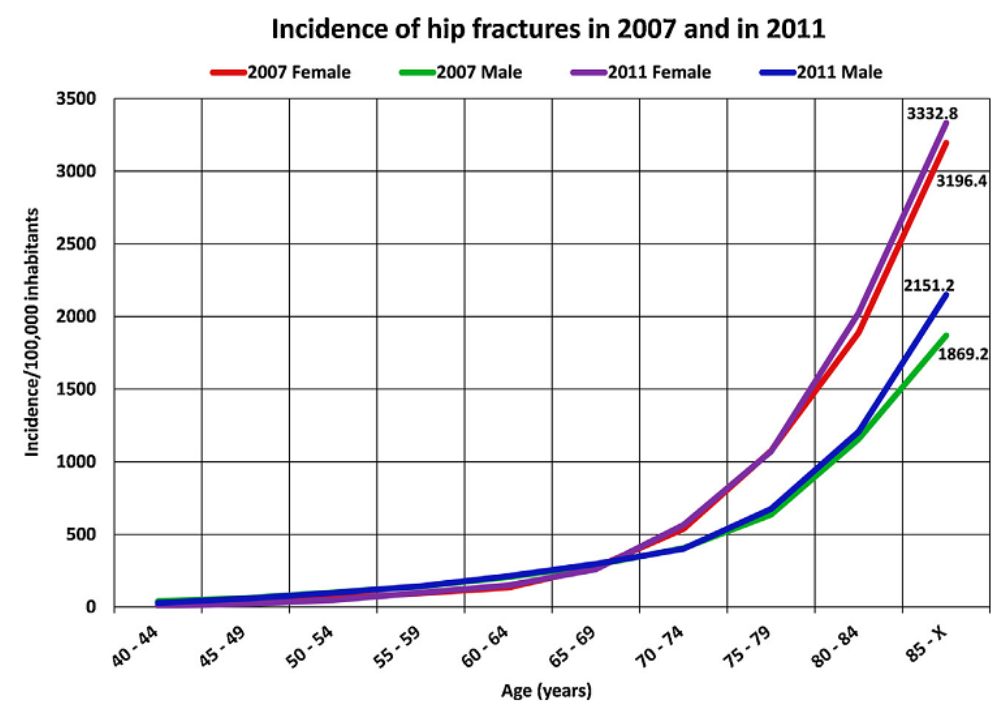

Fig. 3. Incidence of hip fractures in 2007 and in 2011 .

number of hip fractures could be seen (17,432 hip fractures in 2007 and 19,093 in 2011), owing probably to the increasing number of elderly people in the Hungarian society [22].

Among osteoporotic fractures, hip fractures are responsible for the greatest costs and high mortality rates, the male-female ratio is constant at about 30:70 [4,7]. Based on international literature data, $20 \%$ of people with hip fracture die within 1 year, and the 5-year survival is only $41 \%$, with an estimated 740,000 deaths worldwide $[4,23]$. One year after hip fracture the mortality rate is almost double in men than in women: $31 \%$ vs $17 \%[4,7]$. The rate of frailty and co-morbidities in men contribute to higher mortality rates and explains the high rate of long-term care and hospitalisation, as well as greater rates of smoking and alcohol abuse among men can worsen the outcome [18]. Nevertheless, lifetime risk of osteoporotic fracture at age 50 is $20-25 \%$ in Caucasian men (vs $45-55 \%$ in women), which fact should not be neglected [24].

As the incidence of hip fractures showed an exponentially growing tendency with age, adjusting the trend of anti-osteoporotic medications to the population under the greatest risk would be considerable. Appropriate and proportional treatment of the $80+$ populations would be an important issue in both men and women.

A constantly growing utilisation was seen in the case of vitamin $\mathrm{D}$ and calcium compounds in both genders during the investigated period. A possible reason could be the increasing number of articles on vitamin D and calcium supplementation in the past 10 years worldwide, which resulted in wider publicity and guideline implementations of these agents as first-line therapy, also in Hungary.

In contrast, bisphosphonate use showed a gradually declining tendency. The peak age of utilisation was 75-79 years in both genders, while in Australia the peak age was 80-89 years in females and $85-94$ years in males [17]. This difference may be explained by the higher life expectancy rate at birth in Australia, which was 83 years in 2012, compared to 75 years in Hungary [25]. This age utilisation profile only partially corresponds to the population with the highest prevalence of osteoporotic fractures, as hip fractures are the highest in the $85+$ populations in Hungary (Fig. 3). A Swedish study also reported declining probability of bisphosphonate use with increasing age, especially in 85+ age groups [26].

Large differences were seen when comparing utilisation data of different countries. Unfortunately, a reliable explanation of these discrepancies or any similar comparison has not been found in the literature.

The 2 or 3 fold differences in the utilisation rate can partially be explained with the different reimbursement policies of the investigated countries or difference in patient registration system. As an example, in Hungary, as a result of substantial cut in the reimbursement rate, the use of risedronic acid (monotherapy) dropped to one-third of its trade in 2008 compared to 2007, and it still has not reached the 2007 level in 2011.

The different screening methods and the applied diagnostic criteria can also influence the use of bisphosphonates. In Finland and Hungary - and in most European countries - DEXA (DualEnergy X-Ray Absorptiometry) is the gold standard diagnostic tool for osteoporosis [27]. Yet, there is a debate on the reference values of DEXA, the International Osteoporosis Foundation recommends a sex-specific $T$-score, while the WHO recommends using the reference values of a 20 to 30 -year-old white U.S. woman to define DEXA $T$-score (-2.5 T-score) [18]. In a Dutch study, using a $T$-score value $<-2.5$, only $21 \%$ of men and $44 \%$ of women were identified among those sustained non-vertebral fracture [28]. Hence, there is a great need to develop more sensitive fracture prediction tools, and implement them into the diagnostic criteria. Considering several relevant clinical risk factors, FRAX is the most widely used fracture risk assessment tool for prediction of 10 -year probability of a major osteoporotic or hip fracture [29].

The recent concerns about strontium ranelate (Protelos/Osseor) treatment must also be mentioned. Protelos/Osseor must not be used in patients with established, current or past history of ischaemic heart disease, peripheral arterial disease and/or cerebrovascular disease, or those with uncontrolled hypertension (EMA letter No: EMA/84749/2014) [30]. These restrictions are unlikely to cause significant changes in the use of strontium ranelate in Hungary, as similar recommendations were in effect previously.

There are some limitations to our study. NHIF database does not provide full data access for research purposes, therefore the information on ICD codes and age of patients was not complete. Nevertheless, for our analysis ICD codes for the first 3 digits and 5 -year-long age clusters were used. There might be some uncertainties derived from limited ICDs in the case of vitamin D and calcium prescription (E55-E58, vitamin deficiency), since the indication of use is widespread. However, M80 (Osteoporosis with 
pathological fracture) and M81 (Osteoporosis without pathological fracture) codes clearly and sufficiently refer to osteoporosis.

Also, this database does not include over-the-counter medication claims. Thus, in this study we cannot estimate the OTC calcium or vitamin D consumption in Hungary.

\section{Summary and conclusions}

Osteoporosis and osteoporotic fractures are responsible for high hospital admission and mortality rates worldwide and put huge financial burden to the society. Undoubtedly, postmenopausal women are under the greatest risk of osteoporotic bone fractures; however, outcomes are even much worse among male patients.

We found that men are significantly undertreated in all age groups, compared to women. The 10 to 20 -fold difference calls our attention to this unrecognised problem and to the need for extended screening aids.

Our research is the first study that provides both gender- and age-specific information on the use of anti-osteoporotic medications in Hungary, and according to our knowledge there is no such study freely available across Europe. We hope this study will be helpful not only for Hungarian colleagues, but also a gap-filling work for other health care professionals and decision makers in Europe.

\section{Contributors}

Andrea Bor has contributed by participating in the study conception and design, acquisition of data, analysis and interpretation of data, drafting of manuscript and in critical revision, and also has seen and approved the final version. Maria Matuz has contributed by participating in the study conception and design, analysis and interpretation of data and in critical revision. Nóra Gyimesi, Zsuzsanna Biczók and Gyöngyvér Soós have contributed by participating in the study conception and design and in critical revision, and also have seen and approved the final version. Péter Doró has contributed by participating in the study conception and design, acquisition of data, analysis and interpretation of data, drafting of manuscript and in critical revision, and also has seen and approved the final version.

\section{Competing interest}

The authors declare that they have no conflict of interest.

This article does not contain any studies with human participants or animals performed by any of the authors.

\section{Funding}

None.

\section{References}

[1] NIH Consensus Development Panel on Osteoporosis Prevention, Diagnosis, and Therapy. Osteoporosis prevention, diagnosis, and therapy. JAMA 2001;6:785-95.

[2] Hernlund E, Svedbom A, Ivergard M, et al. Osteoporosis in the European Union: medical management, epidemiology and economic burden. A report prepared in collaboration with the International Osteoporosis Foundation (IOF) and the
European Federation of Pharmaceutical Industry Associations (EFPIA). Arch Osteoporos 2013;1-2:136

[3] Cawthon PM. Gender differences in osteoporosis and fractures. Clin Orthop Relat Res 2011;7:1900-5.

[4] Hungarian Society of Osteoporosis and Osteoarthrology. Recognition, prevention and treatment of osteoporosis (Article in Hungarian). Ca \& Bone 2008;11:4-56.

[5] Wilk R, Skrzypek M, Kowalska M, et al. Standardized incidence and trend of osteoporotic hip fracture in Polish women and men: a nine year observation. Maturitas 2014;1:59-63.

[6] Willems JM, de Craen AJ, Nelissen RG, van Luijt PA, Westendorp RG, Blauw G]. Haemoglobin predicts length of hospital stay after hip fracture surgery in older patients. Maturitas 2012;3:225-8.

[7] Forsen L, Sogaard AJ, Meyer HE, Edna T, Kopjar B. Survival after hip fracture: short- and long-term excess mortality according to age and gender. Osteoporo Int 1999;1:73-8.

[8] Horváth C (Article in Hungarian) Osteoporosis - not only disease, but investment?; 2008. http://hetivalasz.hu/pr/a-csontritkulas-nemcsak-betegseghanem-befektetes-is-38258/?cikk_ertekel=1\& ertekeles=1 (accessed 04.04 14).

[9] Birkett DJ. The future of ATC/DDD and drug utilization research. WHO Drug Inform 2002;16:238-40.

[10] WHO Collaborating Centre for Drug Statistics Methodology. Guidelines for ATC classification and DDD assignment. Oslo: Norwegian Institute of Public Health; 2013.

[11] Souich P, Orme M, Erill S. The IUPHAR compendium of basic principles fo pharmacological research in humans. Irvine: IUPHAR Administrative Office: 2014.

[12] Hungarian Central Statistical Office. Available at: http://statinfo.ksh.hu Statinfo/themeSelector.jsp?page $=2 \&$ szst=WNT $($ accessed 24.02.14)

[13] Estonian drug consumption database. Available at: http://pxweb.tai.ee esf/pxweb2008/Database_en/Medicines/Medicines/Medicines.asp (accessed 14.04.14).

[14] Finnish Medicines Agency Fimea and Social Insurance Institution. Finnish statistics on medicines 2010 Helsinki: Finnish Medicines Agency; 2011.

[15] Estonian State Agency of Medicines. Baltic statistics on medicines 2010-2012. Tartu: Estonian State Agency of Medicines; 2013, ISBN 978-9949-33-396-7.

[16] Norwegian Prescription Database. Available at: http://www.norpd no/Prevalens.aspx (accessed on 20.05.14).

[17] Hollingworth SA, Gunanti I, Nissen LM, Duncan EL. Secondary prevention of osteoporosis in Australia: analysis of government-dispensed prescription data. Drugs Aging 2010;3:255-64.

[18] Laurent M, Gielen E, Claessens F, Boonen S, Vanderschueren D. Osteoporosis in older men: recent advances in pathophysiology and treatment. Best Pract Res Clin Endocrinol Metab 2013;4:527-39.

[19] Gielen E, Vanderschueren D, Callewaert F, Boonen S. Osteoporosis in men. Best Pract Res Clin Endocrinol Metab 2011:2:321-35.

[20] Kaufman JM, Audran M, Bianchi G, et al. Efficacy and safety of strontium ranelate in the treatment of osteoporosis in men. J Clin Endocrinol Metab 2013;2:592-601.

[21] Boonen S, Lorenc RS, Wenderoth D, Stoner KJ, Eusebio R, Orwoll ES. Evidence for safety and efficacy of risedronate in men with osteoporosis over 4 years of treatment: results from the 2-year, open-label, extension study of a 2-year, randomized, double-blind, placebo-controlled study. Bone 2012;3:383-8.

[22] Tables of basic data on Hungarian health care. Available at: http:/ tea.gyemszi.hu/ (accessed 20.03.14)

[23] White SC, Atchison KA, Gornbein JA, Nattiv A, Paganini-Hill A, Service SK. Risk factors for fractures in older men and women: the Leisure World Cohort Study. Gend Med 2006;2:110-23.

[24] Lippuner K, Johansson H, Kanis JA, Rizzoli R. Remaining lifetime and absolute 10-year probabilities of osteoporotic fracture in Swiss men and women. Osteoporos Int 2009;7:1131-40,

[25] World Health Organisation life expectancy. Available at: http://apps.who.int gho/data/node.main.3?lang=en (accessed 20.03.14).

[26] Johnell K, Fastbom J. Undertreatment of osteoporosis in the oldest old? A nationwide study of over 700,000 older people. Arch Osteoporos $2009 ; 1-2: 17-23$.

[27] Karjalainen J [dissertation] Novel pulse-echo ultrasound methods for diagnostics of osteoporosis; 2011

[28] Schuit SC, van der Klift M, Weel AE, et al. Fracture incidence and association with bone mineral density in elderly men and women: the Rotterdam Study. Bone 2004;1:195-202

[29] FRAX test. Available at: https://www.shef.ac.uk/FRAX/ (accessed on 2404.14).

[30] Compston J. Strontium ranelate lives to fight another day. Maturitas 2014;2:75-6. 
II. 


\title{
2 Medication use and risk of falls among nursing home residents: 3 a retrospective cohort study
}

\author{
4 Andrea Bor ${ }^{1} \cdot$ Mária Matuz $^{1} \cdot$ Márta Csatordai $^{1} \cdot$ Gábor Szalai $^{1} \cdot$ András Bálint $^{2}$. \\ 5 Ria Benkö $^{1} \cdot$ Gyöngyvér Soós $^{1} \cdot$ Péter Doró $^{1}$
}

6 Received: 16 March 2016/Accepted: 9 January 2017

7 (C) Springer International Publishing 2017

8 Abstract Background Geriatric falls are leading causes 9 of hospital trauma admissions and injury-related deaths. 10 Medication use is a crucial element among extrinsic risk 11 factors for falls. To reduce fall risk and the prevalence 12 of adverse drug reactions, potentially inappropriate 13 medication (PIM) lists are widely used. Objective Our 14 aim was to investigate the possible predictors of geriatric 15 falls annualized over a 5-year-long period, as well as to 16 evaluate the medication use of nursing home residents. 17 Setting Nursing home residents were recruited from the 18 same institution between 2010 and 2015 in Szeged, 19 Hungary. Method A retrospective epidemiological study 20 was done. Patient data were analysed for the first 2112 months of residency. Chi-squared test and Fisher's22 test were applied to compare the categorical variables, 23 Student's $t$ test to compare the continuous variables 24 between groups. Binary logistic regression analysis was 25 carried out to determine the association of falls with 26 other variables found significant in univariate analysis. 27 Microsoft Excel, IBM SPSS Statistics (version 23) and $28 R(3.2 .2)$ programs were used for data analysis. Main 29 outcome measure Falls affected by age, gender, number 30 of chronic medications, polypharmacy, PIM meds. Re31 sults A total of 197 nursing home residents were inclu32 ded, $150(76.2 \%)$ women and $47(23.8 \%)$ men, 55 fallers 33 (annual fall prevalence rate was $27.9 \%$ ) and 142 non34 fallers. Gender was not a predisposing factor for falls

\begin{tabular}{|c|c|c|}
\hline A1 $\mathrm{A} 2$ & $\Delta$ & $\begin{array}{l}\text { Péter Doró } \\
\text { doro@pharm.u-szeged.hu }\end{array}$ \\
\hline A4 & 1 & $\begin{array}{l}\text { Department of Clinical Pharmacy, Faculty of Pharmacy, } \\
\text { University of Szeged, Szikra utca } 8 \text {, Szeged } 6725 \text {, Hungary }\end{array}$ \\
\hline 5 & 2 & $\begin{array}{l}\text { Ösz Nursing Home of Szeged, Zákány utca 25, Szeged } 6724 \text {, } \\
\text { Hungary }\end{array}$ \\
\hline
\end{tabular}

(prevalence in males: 23.4 vs $29.3 \%$ in females, 35 $p>0.05$ ). Fallers were older (mean years $\pm \mathrm{SD}$; 36 $84.0 \pm 7.0)$ than non-fallers $(80.1 \pm 9.3, p<0.01)$. The 37 age $\geq 80$ years was a significant risk factor for falls 38 $(p<0.001)$. The number of chronic medications was 39 higher in male fallers $(12.4 \pm 4.0)$ than in non-fallers 40 $(6.9 \pm 4.2, p<0.001)$. Polypharmacy (taking four or 41 more chronic medications) was a significant risk factor 42 of falls $(p<0.01)$. Those PIMs carrying fall risk were 43 taken by $70.9 \%$ of fallers and $75.3 \%$ of non-fallers 44 $(p>0.05)$. Taking pantoprazole, vinpocetine or trimeta- 45 zidine was a significant risk factor for falls. Conclusion 46 Older age, polypharmacy and the independent use of 47 pantoprazole, vinpocetine, and trimetazidine were found 48 to be major risk factors for falls. Further real-life epi- 49 demiological studies are necessary to confirm the role of 50 particular active agents, and to help professionals prescribe, evaluate and review geriatric medication use.

Keywords Elderly · Fall risk · Nursing home . Polypharmacy $\cdot$ Potentially inappropriate medication

\section{Impacts on practice}

- Older age (above 80 years) is a main risk factor for geriatric falls among nursing home residents.

- Our results showed that polypharmacy is an independent risk factor for falls.

- Taking pantoprazole, vinpocetine or trimetazidine was significant risk factors for falls; therefore patients using these medications may require special attention during the routinely performed medication reviews (the role of trimetazidine as a risk factor for falls was confirmed only by univariate analysis).
6 37 8 9 . . 3 4 5 . 8 0 


\section{Introduction}

Geriatric falls are the leading causes of hospital trauma admissions and injury-related deaths [1]. Approximately one-third of community-dwelling elderly above the age of 65 , and approximately $30-50 \%$ of people living in longterm care institutions fall each year, resulting in bone fractures, worsened quality of life, loss of independence, fear of falling, disability and early death [2,3].

Amongst fall-related low-energy bone fractures, hip fractures are responsible for the greatest costs and high mortality rates: nearly $20 \%$ of people with hip fracture will die within one year. Although falls are more common among older women than men, in the case of hip fracture, the mortality rate is almost double in males than in females (31 vs 17\%) [4-6]. Therefore guidelines and policies on fall prevention need to be adverted on gender perspective, as well as on populations under the greatest risk, such as nursing home residents. According to the Centers for Disease Control and Prevention (CDC), approximately 5\% of adults above 65 years live in nursing homes, but these residents account for about $20 \%$ of deaths from falls in this age group. Although many falls remain unreported, patients often fall more than once a year. In a typical nursing home, the annual average number of falls is 2.6 per patient [1].

Many studies have revealed a variety of factors or conditions that can increase the risk of falling in elderly patients, such as older age, comorbidities, vision disturbance, diabetes and depression [5, 7, 8]. Also, medication use is a crucial element among extrinsic risk factors for falls. Although comorbidities in older people often require taking numerous prescription drugs, taking four or more chronic medications (defined as polypharmacy) was found to be an independent risk factor for falls $[8,9]$. Polypharmacy (PP) also increases the prevalence of drug-related problems (DRPs), such as drug-drug interactions, adverse drug reactions (ADRs), prescription errors and non-adherence $[10,11]$. Though there is no consensus about the exact cut-off value for polypharmacy, usually it is defined as the concomitant use of more than or equal to 4-8 chronic medications [7, 12, 13]. Polypharmacy is quite common in geriatric patients: the prevalence in the U.S. is around 57\%, while a large European study reported $51 \%[14,15]$.

To reduce the risk of falls and to minimize the prevalence of adverse drug reactions, potentially inappropriate medication (PIM) lists have been implemented, among which the 'Beers criteria' is the most widely used, outstarter list [16]. Originally its use was restricted for nursing home residents, then it was extended for any geriatric patients. The most recently updated (2015) list identifies not only the potentially inappropriate drugs, but also offers recommendation on alternative medications or therapies [17].

Following the Beers criteria, numerous countries have created their specific national PIM list, adding or withdrawing medications, adapted to the country's therapeutic practice and pharmaceutical market. Using these medication lists is a substantial strategy to reduce the risk of adverse events and falls in older adults; however, the lists are hardly confirmed by real epidemiological data.

\section{Aim of the study}

In this cohort study our aim was to investigate the possible predictors of geriatric falls annualized over a 5-year-long period, as well as to evaluate the medication use of nursing home residents.

\section{Ethics approval}

The present study was approved by the Regional Human Biomedical Research Ethics Committee of the University of Szeged.

\section{Materials and methods}

A retrospective analysis was done regarding the medication use and fall prevalence in nursing home residents, all recruited from the same institution, between August 2010 and August 2015 in Szeged, Hungary. The main outcome measures were falls affected by age, gender, number of chronic medications, polypharmacy and PIM meds.

\section{Patients and setting}

Every patient who was the resident of the investigated nursing home for at least 12 months was included into the study. Patient data were recorded and analysed for the first 12 months of residency, starting from the date of admission. Relevant medication lists and demographic information were collected from the patient medical documentation of the facility. Detailed data on falls were available from hospital discharge documents since, after noticed falls, all residents were admitted to hospital for further investigation according to the nursing home protocol.

The nursing home provides residential accommodation, meals and 24-hour personal care (residential nursing) for those who find it difficult to cope without assistance. The facility is fully accessible and barrier-free. Daily medical supervision is also ensured (neurologist and gerontologist). 6 (17) . .

\section{2} . . 
Due to the local policy, deceased patients were excluded from this study, since we had no data access on those patients' medical information.

\section{Data analysis and statistical methods}

Microsoft Excel (Microsoft Office 2010, Microsoft Corporation, Redmond, WA), IBM SPSS Statistics for Windows (version 23, IBM Corporation, Armonk, NY) and R (version 3.2.2, R Foundation for Statistical Computing, Vienna, Austria) programs were used for data management and analysis.

A Chi-squared test was applied to compare the categorical variables (e.g. gender) between the investigated groups, and Fisher's test in case of polypharmacy. Student's $t$ test was performed to compare the continuous variables (e.g., age, number of medications) between groups. Polypharmacy is defined as the concomitant use of equal to or more than four chronic medications.

\section{Positive predictive value (PPV)}

We examined the prevalence and PPV with $95 \%$ confidence intervals, to estimate the possible impact of each medication (active substance) on risk of falls by the widely used, basic architecture ( 2 by 2 contingency table) of cohort studies [18].

PPV is the proportion of patients taking a particular (investigated) drug and who had fall(s). In other words it shows the probability of an outcome (fall) if the patient has the tested condition (takes the particular drug). These proportions only have limited validity in clinical practice, however. The predictive values of a clinical test depend critically on the prevalence of the condition (falls) in the patients being tested within a particular environment. [19].

\section{Number needed to harm (NNH)}

$\mathrm{NNH}$ was calculated for those active agents which have high PPV, and where the lower CI 95\% value exceeded the annual fall prevalence rate. The NNH index expresses how many patients need to be exposed to a certain risk-factor (drug) to cause harmful effect (fall) in one patient over a specific time period (1 year) [20, 21]. Nevertheless, NNH values calculated in our study cannot be extended for the entire population of elderly people; they are valid only for those nursing home residents involved in this analysis.

\section{Binary logistic regression analysis}

Binary logistic regression analysis was carried out to determine the association of falls with other variables found significant in univariate analysis. Logistic regression was characterized by the accuracy of test $[20,21]$.

Potentially inappropriate medications

To identify the potentially inappropriate medications, four commonly used PIM lists have been adopted to the Hungarian drug market and to our data on medication use, i.e. the updated Beers criteria (2015), the French LaRoche list (2007), the German Priscus list (2010) and the Austrian Mann list (2012) [17, 22-24]. The adopted list consists of 94 drugs or active ingredients (PIMs), out of which 54 drugs (PIM fall risk) were considered high-risk drugs in terms of falls (based on the rationale of the original lists). The prevalence of exposure to these medicines was illustrated by Venn diagram [25].

\section{Results}

Demography

A total of 197 nursing home residents were included in the study, $150(76.2 \%)$ women and $47(23.8 \%)$ men (Table 1.) Among the 55 fallers (so the annual fall prevalence rate was $27.9 \%$ ), 44 were females and 11 were males. Out of the 142 non-faller residents, 106 were females and 36 were males. The gender was not found to be a predisposing factor for falls (prevalence in males: 23.4 vs $29.3 \%$ in females, $p>0.05$ ). Bone fractures occurred in 24 patients (5 males and 19 females, $43.6 \%$ of fallers).

Regarding age, fallers were older $(84.0 \pm 7.0$ years $)$ than non-fallers $(80.1 \pm 9.3$ years, $p<0.01)$. The age above or equal to 80 years was found to be a significant risk factor for falls $(p<0.001)$. Among fallers, 47 residents $(85.5 \%)$ were 80 years old or older, and all the 13 multiple fallers (more than 1 fall per year) were in this group.

\section{Medication patterns}

The number of chronic medications taken did not significantly differ between fallers and non-fallers $(9.1 \pm 3.8$ vs $8.0 \pm 3.9, p>0.05$ ) (Table 1), but did differ among male patients (fallers $12.4 \pm 4.0$ vs non-fallers $6.9 \pm 4.2, p<$ 0.001). Also, polypharmacy (taking four or more chronic medications) was a significant risk factor of falls ( $p=$ 0.010).

\section{Potentially inappropriate medications}

Regarding the prevalence of PIM medication use, $77.2 \%$ of the residents took one or more PIM-list drugs, and there 
Int J Clin Pharm

Table 1 Study population characteristics

\begin{tabular}{|c|c|c|c|c|c|}
\hline & & $\begin{array}{l}\text { Fallers } \\
(55 ; 27.9 \%)\end{array}$ & $\begin{array}{l}\text { Non-fallers } \\
(142 ; 72.1 \%)\end{array}$ & $p$ vale, test & $\begin{array}{l}\text { Total } \\
(197 ; 100.0 \%)\end{array}$ \\
\hline \multirow[t]{2}{*}{ Gender } & Females ( $\%$ of all females) & $44(29.3 \%)$ & $106(70.7 \%)$ & $p=0.427$, Chi-squared test & $150(76.2 \%)$ \\
\hline & Males ( $\%$ of all males) & $11(23.4 \%)$ & $36(76.6 \%)$ & & $47(23.8 \%)$ \\
\hline \multirow[t]{2}{*}{ Age (years) } & Mean \pm SD & $84.0 \pm 7.0$ & $80.1 \pm 9.3$ & $p=0.002, t$ test & $81.2 \pm 8.9$ \\
\hline & Min-max & $61-99$ & $52-104$ & - & $52-104$ \\
\hline \multicolumn{2}{|c|}{ Age group 80 years or older ( $\%$ of group) } & $47(35.9 \%)$ & $84(64.1 \%)$ & $p<0.001$, Chi-squared test & $131(66.5 \%)$ \\
\hline \multicolumn{2}{|c|}{ Age group less than 80 years ( $\%$ of group) } & $8(12.1 \%)$ & $58(87.9 \%)$ & & $66(33.5 \%)$ \\
\hline \multirow[t]{4}{*}{ Number of chronic medications } & Mean \pm SD & $9.1 \pm 3.8$ & $8.0 \pm 3.9$ & $p=0.093, t$ test & $8.32 \pm 3.88$ \\
\hline & Min-max & $3-19$ & $0-18$ & - & $0-19$ \\
\hline & Males (mean $\pm \mathrm{SD}$ ) & $12.4 \pm 4.0$ & $6.9 \pm 4.2$ & $p<0.001, t$ test & $8.2 \pm 4.7$ \\
\hline & Females (mean \pm SD) & $8.3 \pm 3.3$ & $8.4 \pm 3.7$ & $p=0.810, t$ test & $8.4 \pm 3.6$ \\
\hline \multirow[t]{2}{*}{ Polypharmacy } & Yes (\% of group) & $54(98.2 \%)$ & $122(85.9 \%)$ & $p=0.010$, Fisher's-test & $176(89.3 \%)$ \\
\hline & No (\% of group) & $1(1.8 \%)$ & $20(14.1 \%)$ & & $21(10.7)$ \\
\hline \multirow[t]{2}{*}{ PIM } & Yes ( $\%$ of group) & $40(72.7 \%)$ & $112(78.9 \%)$ & $p=0.357$, Chi-squared test & $152(77.2 \%)$ \\
\hline & No (\% of group) & $15(27.3 \%)$ & $30(21.1 \%)$ & & $45(22.8 \%)$ \\
\hline \multirow[t]{2}{*}{ PIM fall risk } & Yes ( $\%$ of group) & $39(70.9 \%)$ & $107(75.3 \%)$ & $p=0.523$, Chi-squared test & $146(74.1 \%)$ \\
\hline & No (\% of group) & $16(29.1 \%)$ & $35(24.6 \%)$ & & $51(25.9 \%)$ \\
\hline
\end{tabular}

Polypharmacy concomitant use of minimum four or more chronic medications; PIM Potentially inappropriate medication use; PIM fall risk PIMs carrying risk of falls

was no significance in prevalence between fallers and nonfallers (72.7 vs $78.9 \%, p>0.05$ ). Those PIMs carrying risk of falls were taken by $70.9 \%$ of fallers and $75.3 \%$ of nonfallers $(p>0.05)$. Comparing to PIM prevalence, polypharmacy occurred in $85.9 \%$ non-faller patients, but in 98.2\% fallers $(p<0.01)$. PIM use was illustrated on the Venn diagram (Fig. 1a, b). To provide better understanding, we also included the age dimension into this visualisation.

\section{Drugs and falls}

Except for two non-medicated residents, 195 were taking 227 different drugs, out of which 22 drugs were taken by at least $10 \%$ of the patients (minimum 20 individuals, 1 Table 2).

For the most prevalent drugs, positive predictive values (with 95\% confidence intervals) were calculated to estimate the impact of each medication on fall risk. Considering the $27.9 \%$ annual fall prevalence rate in the nursing home, the lower confidence interval exceeded this margin in case of trimetazidine (PPV (95\% CI), 0.48, (0.30-0.66), vinpocetine $0.44(0.31-0.59)$ and pantoprazole 0.40 (0.30-0.52). Hence, those drugs seem to be significant risk factors for falls (Table 2; Fig. 2). Giving an example for better understanding, expanding the definition of PPV, the $0.40 \mathrm{PPV}$ of pantoprazole shows the proportion of patients who used pantoprazole and who had fall(s). This means that taking the drug increases the fall prevalence rate by approximately $12 \%$ (compared to the annual $27.9 \%$ fall prevalence rate).

For the same drugs, the number needed to harm $(\mathrm{NNH}$, 95\% CI) was calculated (groups were the following: particular drug user or non-user, and the outcome/risk was falls). Accordingly, approximately 4-5 patients are needed to be exposed to trimetazidine and vinpocetine use to sustain a fall, while this number is about 6 in the case of pantoprazole exposure (Table 3 ). These numbers are clinically remarkable. We would like to emphasize that the $\mathrm{NNH}$ values calculated above cannot be extended for the entire population of older adults; they are valid only for the involved nursing home residents.

The variables of the binary logistic regression model were the following: age group 80 years and above, persons taking pantoprazole, vinpocetine or trimetazidine. Binary logistic regression confirmed the significant impact of the $80+$ age group, pantoprazole, and vinpocetine on fall risk, odd ratios were respectively $3.92,2.59$ and 2.32 , with $73.6 \%$ accuracy detected, but did not confirm the impact of trimetazidine (Table 4).

\section{Discussion}

A retrospective cohort study was carried out over a period of five years (2010-2015) regarding the medication use and fall prevalence among nursing home residents in Szeged, Hungary. We found $27.9 \%$ annual fall prevalence rate 
A

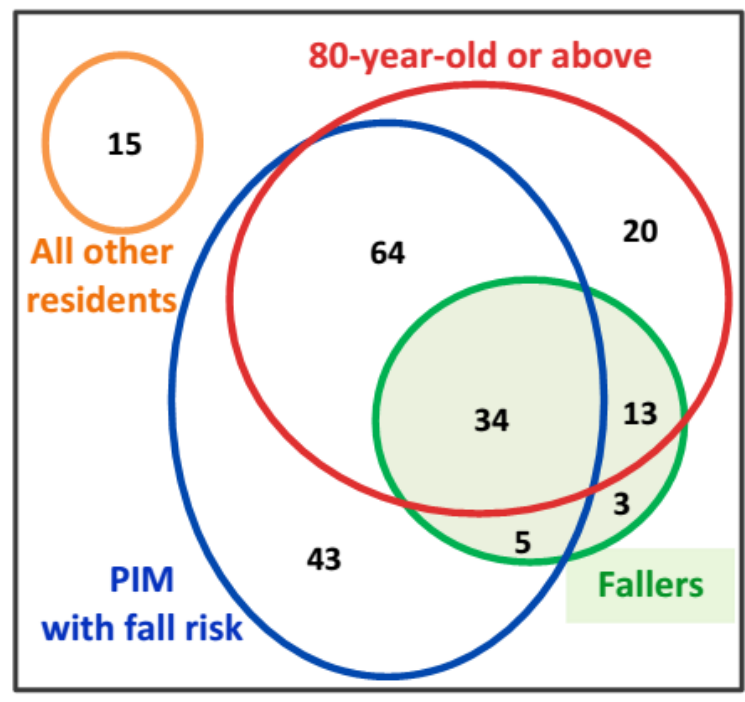

B

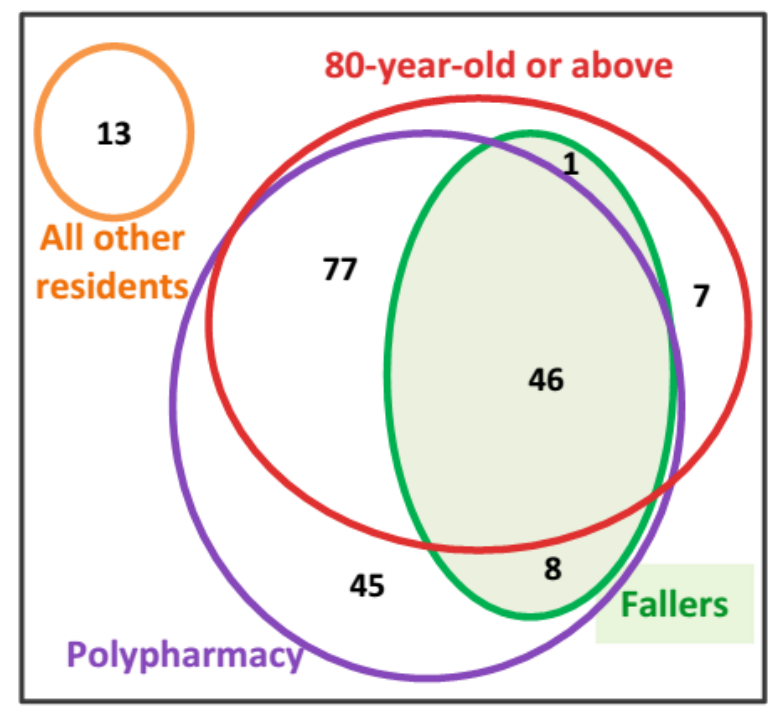

Fig. 1 a Venn diagram illustrates the populations (sets) that were subject to multiple drug use: residents taking potentially inappropriate medications (PIM) with fall risk; fallers; patients who were 80 years old or older, and those who were not part of the other three sets. b Venn diagram illustrates the populations (sets) that were subject to multiple drug use: those residents taking four or more chronic drugs (Polypharmacy); fallers; patients who were 80 years old or older, and those who were not part of the other three sets among nursing home residents, which is slightly lower than the literature data. According to CDC and WHO reports, approximately $30-50 \%$ of people living in long-term care institutions fall each year, which is twice the rate of falls among community-dwelling older adults, and the frequency of falls increases with age $[1,2,26]$. Our results correspond to these findings: the age of 80 years or above was found to be statistically significant risk factor of falls, and fallers were 4 years older than non-faller residents on average. Therefore, attention should be paid to the $80+$ population, since they had almost a fourfold risk of falling (odds ratio 3.92 ) compared to those who were under the age of 80 years.

Although many geriatricians consider polypharmacy (defined as taking four or more chronic medications) to be unavoidable among older patients, PP was a significant risk factor of falls in our study, as it is supported by different surveys and reviews $[5,7,13]$.

Higher numbers of chronic medications was a predisposing factor for falls in male patients. This is an important finding, since fatal fall outcome rates are much higher in men $(46 \%)$ than in women $(27 \%)$ over the age of 65 years [27]. The underlying causes of higher incidence in men are not obvious. Some studies found that males suffer from more co-morbid conditions or they may fall from greater heights and, having poorer health status, they are less likely to survive a fall-related injury than women of comparable age $[27,28]$. Among the potential causes, the greater rates of smoking and alcohol abuse in men, along with commoner causes of secondary osteoporosis (e.g., glucocorticoid excess and hypogonadism) can be mentioned [29, 30]. As was highlighted earlier, the mortality rates are also nearly double in men than in women after sustaining a hip fracture [4-6]. Thus guidelines and policies on fall prevention need to be deigned on gender perspective, particularly in vulnerable nursing home populations.

As the most serious non-fatal consequence of falls, bone fractures occurred in 24 patients (43.6\% among fallers). Although huge differences can be seen in fracture rates worldwide, our study reports higher percentages than a Sweden study $(1-33 \%)$ or a US study $(10-25 \%)$ do, and lower than the one identified in a recent Australian paper (about 48\%) [31-33].

One possible way of reducing fall risk (and consequences) of elderly patients is the frequent and regular medication review, as some of the medications are considered potentially inappropriate for elderly people [17, 22-24]. Although our results did not show a difference in the number of overall PIM-use between fallers and nonfallers, three active agents have emerged from the others. Neither trimetazidine nor vinpocetine have been considered as PIM agents in the literature previously. Pantoprazole was included in the 2015 Beers criteria, but was not included in any PIM lists before. The updated Beers criteria suggests the avoidance of the use of pantoprazole beyond 8 weeks without justification, since long-term proton-pump inhibitor exposure carries high risk of Clostridium difficile infection, bone loss and fractures. Thus, our empirical findings extend the relevancy of 
Int J Clin Pharm

Table 2 Positive predictive values (PPV) of drugs (with 95\% CI confidence intervals)

\begin{tabular}{llcl}
\hline Active substance & No. of takers $(\%)$ & No. of fallers & PPV (95\% CI) \\
\hline Trimetazidine & $\mathbf{2 3}(\mathbf{1 1 . 6 8} \%)$ & $\mathbf{1 1}$ & $\mathbf{0 . 4 8}(\mathbf{0 . 3 0 - 0 . 6 6 )}$ \\
Isosorbide mononitrate & $20(10.15 \%)$ & 9 & $0.45(0.26-0.65)$ \\
Vinpocetine & $\mathbf{3 6}(\mathbf{1 8 . 2 7} \%)$ & $\mathbf{1 6}$ & $\mathbf{0 . 4 4}(\mathbf{0 . 3 1 - 0 . 5 9 )}$ \\
Tiapride & $28(14.21 \%)$ & 12 & $0.43(0.27-0.60)$ \\
Atorvastatin & $29(14.72 \%)$ & 12 & $0.41(0.27-0.58)$ \\
Pantoprazole & $\mathbf{5 2}(\mathbf{2 6 . 4 \% )}$ & $\mathbf{2 1}$ & $\mathbf{0 . 4 0}(\mathbf{0 . 3 0 - 0 . 5 2})$ \\
Allopurinol & $21(10.66 \%)$ & 8 & $0.38(0.21-0.58)$ \\
Glyceryl trinitrate & $36(18.27 \%)$ & 13 & $0.36(0.24-0.51)$ \\
Famotidine & $33(16.75 \%)$ & 11 & $0.33(0.21-0.49)$ \\
Levothyroxine sodium & $30(15.23 \%)$ & 10 & $0.33(0.20-0.50)$ \\
Acetylsalicylic acid & $74(37.56 \%)$ & 24 & $0.32(0.25-0.41)$ \\
Alprazolam & $63(31.98 \%)$ & 20 & $0.32(0.23-0.42)$ \\
Bisoprolol & $33(16.75 \%)$ & 10 & $0.30(0.18-0.46)$ \\
Amlodipine & $42(21.32 \%)$ & 12 & $0.29(0.18-0.42)$ \\
Pentoxifylline & $29(14.72 \%)$ & 8 & $0.28(0.15-0.45)$ \\
Metoprolol & $43(21.83 \%)$ & 10 & $0.23(0.14-0.36)$ \\
Furosemide & $65(32.99 \%)$ & 15 & $0.23(0.16-0.33)$ \\
Potassium chloride & $68(34.52 \%)$ & 15 & $0.22(0.15-0.31)$ \\
Perindopril and amlodipine & $28(14.21 \%)$ & 6 & $0.21(0.10-0.39)$ \\
Acenocoumarol & $20(10.15 \%)$ & 4 & $0.20(0.08-0.42)$ \\
Piracetam & $40(20.3 \%)$ & 7 & $0.18(0.09-0.31)$ \\
metformin & $22(11.17 \%)$ & 3 & $0.14(0.05-0.34)$ \\
\hline
\end{tabular}

Displayed drugs were taken by minimum 20 individuals (10\% of all residents)

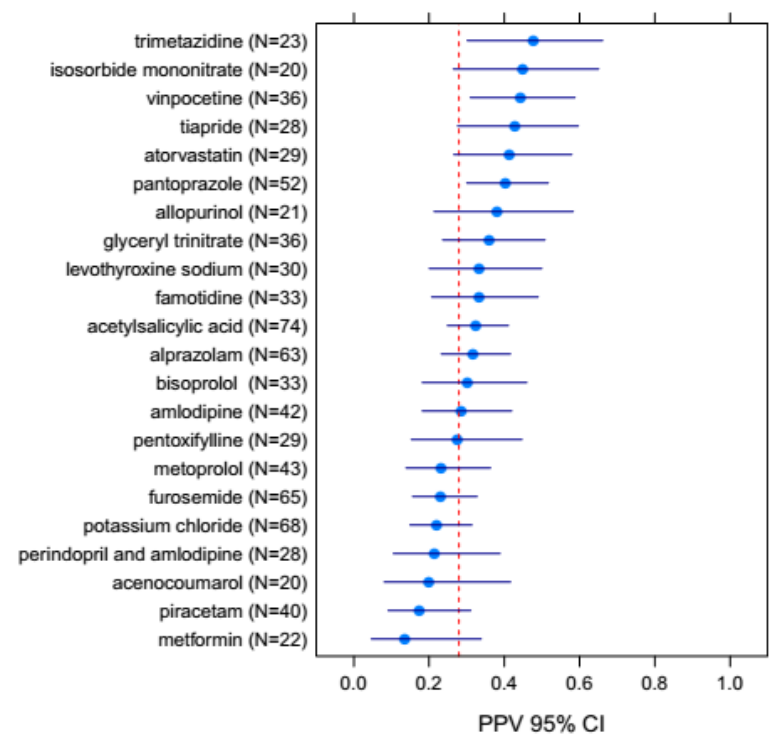

Fig. 2 Positive predictive values (PPV) of drugs with $95 \% \mathrm{CI}$ confidence intervals ( $\mathrm{N}=$ number of drug users). Dashed red line shows the annual fall prevalence rate $(27.9 \%)$ in the nursing home. Displayed drugs were taken by minimum $10 \%$ of all residents

pantoprazole being mentioned as a PIM agent with a new aspect: its use showed 2.5 -fold risk of falls compared to non-takers, and one in every six patients would be expected
Table 3 Number needed to harm $(\mathrm{NNH})$ values (with $95 \% \mathrm{CI}$ confidence intervals) of trimetazidine, vinpocetine and pantoprazole $(\mathrm{N}$ : number of takers)

\begin{tabular}{lll}
\hline Drugs (number of drug users) & $\mathrm{NNH}$ & $95 \% \mathrm{CI}$ \\
\hline Trimetazidine $(\mathrm{N}=23)$ & 4.5 & $2.3-55.1$ \\
Vinpocetine $(\mathrm{N}=36)$ & 5 & $2.7-32.6$ \\
Pantoprazole $(\mathrm{N}=52)$ & 5.9 & $3.2-47$ \\
\hline
\end{tabular}

to result in a fall (NNH value 5.9). As stated in the summary of product characteristics (SPC), severe hypomagnesaemia has been reported in patients, causing fatigue, tetany, delirium, convulsions and dizziness, especially on long-term use (more than 3 months), which can directly lead to geriatric falls [34]. As pantoprazole is an extensively used proton pump inhibitor, its side effects are widely studied. In fact, several recent articles suggest that its use in high doses over long durations ( $>1$ year) may modestly increase the risk of bone fractures; thus, patients at risk of osteoporosis should receive adequate intake of vitamin D and calcium, and should be kept under regular surveillance [34, 35].

Both vinpocetine (nootropic agent) and trimetazidine (anti-anginal agent) can have side effects that may increase 
Table 4 Results of binary logistic regression analysis (95\% CI confidence interval; OR odds ratio)

\begin{tabular}{lll}
\hline Variables & Coefficients $(p$ value $)$ & OR $(95 \%$ CI $)$ \\
\hline Age group 80 years old or above & $1.3660(p=0.00175)$ & $3.92(1.67-9.22)$ \\
Pantoprazole & $0.9498(p=0.01049)$ & $2.59(1.25-5.35)$ \\
Vinpocetine & $0.8411(p=0.03760)$ & $2.32(1.049-5.12)$ \\
Trimetazidine & $0.7181(p=0.13296)$ & $2.05(0.80-5.23)$ \\
\hline
\end{tabular}

the risk of falls, such as tremors, gait instability and dizziness [36-38]. However, we could not find any research that would confirm the direct association between falls and the use of these medications. Our results from the binary logistic regression analysis revealed that taking vinpocetine will double the risk of falls (odds ratio 2.32), and the obtained $\mathrm{NNH}$ values suggest that every fourth or fifth exposure to trimetazidine or vinpocetine will result in a fall-within the given circumstances. We would like to emphasize that the role of trimetazidine as a risk factor for falls was confirmed only by univariate analysis (Table 2). Larger patient numbers are necessary to support this finding, since the more robust multivariate analysis did not confirm this result (Table 4).

The use of tiapride PPV (CI 95\%) $0.43(0.27-0.60)$, atorvastatin $0.41(0.27-0.58)$ or isosorbide mononitrate $0.45(0.26-0.65)$ was found to be a statistically non-significant (as the confidence interval overlap the average annual fall rate), but still mentionable, risk for falls.

Our methods applied in this study would fit in larger population analysis as well, and it may allow us deeper understanding of the role of each medication (or their combinations) concerning falls, especially as geriatric falls are multifactorial. Hence an explicit detachment of the causative circumstances is challenging. Physical state, impaired balance and gait, older age, visual impairment, cognitive decline and environmental factors all carry remarkable fall risk $[5,7]$. Despite these facts, the most broadly examined iatrogenic risk factors are polypharmacy and PIM use, since those are closely associated with ageing [9, 13-15, 17, 39]. As mentioned earlier, wider, comprehensive epidemiological studies would be necessary to confirm the role of particular active agents, and to help professionals prescribe, evaluate and review geriatric medication use by real-life epidemiological data. Our results may contribute to and inspire further research in this field.

\section{Limitations of the study}

The source of data for our analysis performed came from the same nursing home, and we did not have access to the medical information of deceased patients. This limitation may cause some distortion in our results. Furthermore, while some falls may have remained hidden and unreported for any reason, the documented cases were well-established. Finally, larger patient data are needed to confirm our findings, since we had relatively small sample sizes for epidemiological analyses.

\section{Conclusions}

A retrospective cohort study was performed regarding medication use and fall risk among nursing home residents. Older age ( 80 years or above), polypharmacy, and the independent use of three active agents (pantoprazole, vinpocetine, or trimetazidine) were found to be major risk factors for falls. High numbers of chronic medications taken was a significant risk factor in male patients. Our results showed that polypharmacy itself could be defined as an independent risk factor for falls. Nevertheless, the benefit-to-risk ratio of fall-risk drugs also should be taken into account for safe prescribing. Drug-related problems can be reduced by means of the potentially inappropriate medication lists; however, these theoretical criteria need to be confirmed by real-life epidemiological data. Our methods and results could serve as a strong base for further research in this field, as well as they can attract health care professionals' attention to the most vulnerable populations of elderly patients in terms of falls.

Funding None.

Conflicts of interest The authors declare that they have no conflict of interest.

Ethical approval All procedures performed in studies involving human participants were in accordance with the ethical standards of the institutional and/or national research committee and with the 1964 Helsinki declaration and its later amendments or comparable ethical standards. For this type of study formal consent is not required.

\section{References}

1. Centers for Disease Control and Prevention Falls in Nursing Homes. Updated 2015 June 30. http://www.cdc.gov/Home andRecreationalSafety/Falls/nursing.html. Accessed 2 Feb 2016.

2. World Health Organization Global Report on Falls Prevention in Older Age. 2007. http://www.who.int/ageing/projects/falls_pre vention_older_age/en/. Accessed 22 Jan 2016.

\section{1}

452 
3. Ambrose AF, Cruz L, Paul G. Falls and fractures: a systematic approach to screening and prevention. Maturitas. 2015;82:85-93.

4. Hernlund E, Svedbom A, Ivergard M, Compston J, Cooper C, Stenmark J, et al. Osteoporosis in the European Union: medical management, epidemiology and economic burden. A report prepared in collaboration with the International Osteoporosis Foundation (IOF) and the European Federation of Pharmaceutical Industry Associations (EFPIA). Arch Osteoporos. 2013;8:136.

5. Cawthon PM. Gender differences in osteoporosis and fractures. Clin Orthop Relat Res. 2011;469:1900-5.

6. Bor A, Matuz M, Gyimesi N, Biczok Z, Soos G, Doro P. Gender inequalities in the treatment of osteoporosis. Maturitas. 2015;80:162-9.

7. Freeland KN, Thompson AN, Zhao Y, Leal JE, Mauldin PD, Moran WP. Medication use and associated risk of falling in a geriatric outpatient population. Ann Pharmacother. 2012;46: 1188-92.

8. Wu TY, Chie WC, Yang RS, Liu JP, Kuo KL, Wong WK, et al. Factors associated with falls among community-dwelling older people in Taiwan. Ann Acad Med Singap. 2013;42:320-7.

9. Weber V, White A, McIlvried R. An electronic medical record (EMR)-based intervention to reduce polypharmacy and falls in an ambulatory rural elderly population. J Gen Intern Med. 2008;23: 399-404.

10. Willeboordse F, Grundeken LH, van den Eijkel LP, Schellevis FG, Elders PJ, Hugtenburg JG. Information on actual medication use and drug-related problems in older patients: questionnaire or interview? Int J Clin Pharm. 2016:38:380-7.

11. Chau SH, Jansen AP, van de Ven PM, Hoogland P, Elders PJ, Hugtenburg JG. Clinical medication reviews in elderly patients with polypharmacy: a cross-sectional study on drug-related problems in the Netherlands. Int J Clin Pharm. 2016;38:46-53.

12. Ziere G, Dieleman JP, Hofman A, Pols HA, van der Cammen TJ, Stricker BH. Polypharmacy and falls in the middle age and elderly population. Br J Clin Pharmacol. 2006;61:218-23.

13. Zia A, Kamaruzzaman SB, Tan MP. Polypharmacy and falls in older people: balancing evidence-based medicine against falls risk. Postgrad Med. 2015;127:330-7.

14. Hajjar ER, Cafiero AC, Hanlon JT. Polypharmacy in elderly patients. Am J Geriatr Pharmacother. 2007:5:345-51.

15. Fialova D, Topinkova E, Gambassi G, Finne-Soveri H, Jonsson $\mathrm{PV}$, Carpenter I, et al. Potentially inappropriate medication use among elderly home care patients in Europe. JAMA. 2005;293: 1348-58.

16. Beers MH, Ouslander JG, Rollingher I, Reuben DB, Brooks J, Beck JC. Explicit criteria for determining inappropriate medication use in nursing home residents. UCLA Division of Geriatric Medicine. Arch Intern Med. 1991;151:1825-32.

17. American Geriatrics Society. Updated beers criteria for potentially inappropriate medication use in older adults. J Am Geriatr Soc. 2015;2015(63):2227-46.

18. Mercaldo ND, Lau KF, Zhou XH. Confidence intervals for predictive values with an emphasis to case-control studies. Stat Med. 2007;26:2170-83.

19. Altman DG, Bland JM. Diagnostic tests 2: predictive values. BMJ. 1994;309:102.

20. Agresti A. Categorical Data Analysis. 2nd ed. New York: Wiley; 2002.
21. Agresti A, Caffo B. Simple and effective confidence intervals for proportions and difference of proportions result from adding two successes and two failures. Am Stat. 2000;54:280-8.

22. Laroche ML, Charmes JP, Merle L. Potentially inappropriate medications in the elderly: a French consensus panel list. Eur J Clin Pharmacol. 2007;63:725-31.

23. Holt S, Schmiedl S, Thurmann PA. Potentially inappropriate medications in the elderly: the PRISCUS list. Dtsch Arztebl Int. 2010;107:543-51.

24. Mann E, Bohmdorfer B, Fruhwald T, Roller-Wirnsberger RE, Dovjak P, Duckelmann-Hofer C, et al. Potentially inappropriate medication in geriatric patients: the Austrian consensus panel list. Wien Klin Wochenschr. 2012;124:160-9.

25. Bjerrum L, Rosholm JU, Hallas J, Kragstrup J. Methods for estimating the occurrence of polypharmacy by means of a prescription database. Eur J Clin Pharmacol. 1997;53:7-11.

26. Rubenstein LZ. Preventing falls in the nursing home. JAMA 1997;278:595-6.

27. Stevens JA. Falls among older adults-risk factors and prevention strategies. J Safety Res. 2005;36:409-11.

28. Fatalities and injuries from falls among older adults-United States, 1993-2003 and 2001-2005. MMWR Morb Mortal Wkly Rep. 2006:55:1221-1224.

29. Laurent M, Gielen E, Claessens F, Boonen S, Vanderschueren D. Osteoporosis in older men: recent advances in pathophysiology and treatment. Best Pract Res Clin Endocrinol Metab. 2013;27:527-39.

30. Gielen E, Vanderschueren D, Callewaert F, Boonen S. Osteoporosis in men. Best Pract Res Clin Endocrinol Metab. 2011;25:321-35.

31. Fonad E, Wahlin TB, Winblad B, Emami A, Sandmark H. Falls and fall risk among nursing home residents. J Clin Nurs. 2008; 17:126-34.

32. Rubenstein LZ. Falls in older people: epidemiology, risk factors and strategies for prevention. Age Ageing. 2006;35(Supp 2):ii37-41.

33. Russell M, Clapperton A, Vu T, Day L. Trends in fall-related hospitalisations in older people living in aged care facilities. Osteoporos Int. 2015;26:1219-24.

34. Pantoprazole Summary of Product Characteristics. https://www. medicines.org.uk/emc/medicine/2518. Accessed 23 Feb 2016.

35. Ozdil K, Kahraman R, Sahin A, Calhan T, Gozden EH, Akyuz U, et al. Bone density in proton pump inhibitors users: a prospective study. Rheumatol Int. 2013;33:2255-60.

36. Vinpocetine Summary of Product Characteristics. https://www. ogyei.gov.hu/gyogyszeradatbazis/index.php?action=show_detail s\&item=16779. Accessed 24 Feb 2016.

37. Trimetazidine Summary of Product Characteristics. https://www. ogyei.gov.hu/gyogyszeradatbazis/index.php?action=show_detail s\&item=27756. Accessed 24 Feb 2016.

38. European Medicines Agency Recommendation on restricted use of trime-tazidine-containing medicines. 2012. http://www.ema. europa.eu/ema/index.jsp?curl=pages/news_and_events/news/ 2012/06/news_detail_001541.jsp\&mid=WC0b01ac058004d5c1. Accessed 24 Feb 2016

39. Bor A, Matuz M, Doro P, Viola R, Soos G. Drug-related problems in the elderly. Orv Hetil. 2012;153:1926-36. 
III. 


\title{
Az időskori gyógyszeralkalmazás problémái
}

\author{
Bor Andrea dr. - Matuz Mária dr. - Doró Péter dr. \\ Viola Réka dr. - Soós Gyöngyvér dr.
}

Szegedi Tudományegyetem, Gyógyszerésztudományi Kar, Klinikai Gyógyszerészeti Intézet, Szeged

\begin{abstract}
A fejlett országok lakosságának elöregedése napjaink általános problémája. Az egészségügyre nehezedő teher különösen nagy, hiszen a kor előrehaladtával a betegségek, különösen a krónikus betegségek száma nő meg ebben a populációban. A halmozott gyógyszerszedés, a polypharmatia jellemző az idős betegekre. Bár az időskori komorbiditás megköveteli több hatóanyag valós indikáción alapuló alkalmazását, viszont a polypharmatia növeli az interakciók és a nemkívánatos gyógyszerhatások kialakulásának esélyét, csökkenhet a betegcompliance, romlik az életminőség és jelentős anyagi megterhelést jelent mind a beteg, mind pedig a társadalom számára. Az idős betegek gyógyszeralkalmazásából eredő problémáinak csökkentése érdekében születtek meg azok a listák, amelyek a potenciálisan nem megfelelő hatóanyagokat, dózisokat gyújtik össze. Az egyik legkorábbi lista az úgynevezett Beers-kritériumok. Az ezekben szereplő hatóanyagok alkalmazása időskorban nem javallott, illetve kockázatos. A külföldi példák nyomán a szerzók a hazai gyógyszerkincshez alkalmazkodó listát állítottak össze, átvéve a nem megfelelőség indoklását és alternatív terápiás javaslatokat is. Orv. Hetil., 2012, 153, 1926-1936.
\end{abstract}

Kulcsszavak: időskor, komorbiditás, polypharmatia, prevenció

\section{Drug-related problems in the elderly}

The aging population in developed countries is a growing problem nowadays. The burden on healthcare is particularly high, since the prevalence of the diseases, especially chronic diseases increases with age. Prevalence of polypharmacy is common among elderly patients. While comorbidities require usage of several active agents with evidence based indication, polypharmacy increases the likelihood of interactions and adverse drug reactions, reduces patient compliance, affects quality of life and puts a significant financial burden on the patient and society. In order to reduce drug-related problems among the elderly, different lists of potentially inappropriate drugs and doses were created. One of the earliest known lists is the "Beers criteria". The use of listed drugs is risky and not recommended for elderly patients. Following foreign examples, a list was compiled and adapted to the Hungarian drug spectrum based on the main concerns and alternative therapeutic suggestions. Orv. Hetil., 2012, 153, 1926-1936.

Keywords: elderly patients, comorbidity, polypharmacy, prevention

(Beérkezett: 2012. október 9.; elfogadva: 2012. október 25.)

\section{Rövidítések}

ATC $=($ Anatomical Therapeutic Chemical Classification System) Anatómiai Terápiás Kémiai Osztályozási Rendszer; $\mathrm{DRP}=($ drug-related problems $)$ gyógyszeralkalmazásból eredó problémák; PIM = (potentially inappropriate medications) potenciálisan nem megfelelő gyógyszerek; $\mathrm{WHO}=($ World Health Organization) Egészségügyi Világszervezet

Általános tapasztalat szerint a gyógyszerhasználat folyamatos növekedésének sajnálatos velejárója a gyógyszerekkel kapcsolatos gondok (drug-related problems
- DRP) szaporodása. Mivel a rendszeres, krónikus gyógyszerfogyasztók döntően az idős, 65 év feletti személyek közül kerülnek ki, a gyógyszeralkalmazáshoz kapcsolódó, ám speciális gondoskodással csökkenthető problémák is túlnyomóan az idős betegeket érintik. Számos esetben az egyidejúleg fennálló különböző betegségek, komorbiditások indokolják ugyan többféle gyógyszer párhuzamos rendelését, de a szükséges hatóanyagok, adagok, az alkalmazási mód és időtartam meghatározása megkülönböztetett figyelmet kíván. A gerontológiai gyógyszerelés általános nehézségeit és a potenciálisan problémás gyógyszereket foglalja össze közleményünk. 


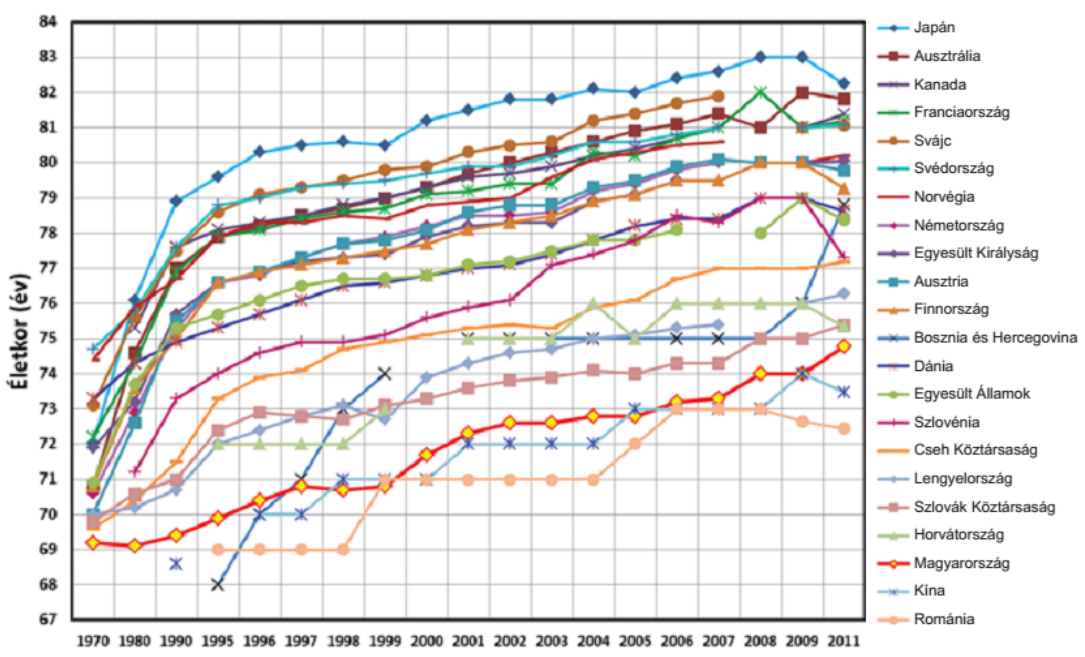

\section{Demográfiai helyzet}

A társadalom elöregedése napjainkban a fejlett országokban megfigyelhető, jól dokumentált jelenség. Magyarországon nemcsak az idős lakosság aránya növekszik, hanem a társadalom öregedésének üteme is gyorsul. Míg 2010-ben 17\% körüli volt a 65 éven felüliek aránya hazánkban, addig 2060-ra már 32\%-ra becsülik az idősek arányát $[1,2,3]$. Ennek hátterében részben az úgynevezett Ratkó-korszak népesedéspolitikája állhat, de sokkal számottevőbb az alacsony születésszám és a várható élettartam meghosszabbodásának jelentősége. A WHO adatai szerint - az 1. ábrán szereplő 22 országot figyelembe véve - 2011-ben a születéskor várható élettartam 70,1 év férfiak és 78,1 év nók körében, átlagosan 74,8 év. Bár a várható élettartam folyamatosan növekvő tendenciát mutat, más fejlett országokhoz viszonyítva hazánk még mindig a legalacsonyabbak között foglal helyet (1. ábra) $[4,5]$.

Hazai és nemzetközi irodalmi adatok az időskor alsó határát egyre inkább 65 évben határozzák meg a korábbi 60 év helyett, amely tény jól példázza az idősödés jelenségének térhódítását, amely magával hozza a nyugdíjkorhatár emelkedését is $[6,7,8,9,10,11,12]$.

\section{Halmozott gyógyszerszedés}

$\mathrm{Az}$ öregedés tényének jelentős egészségügyi vonatkozása van, hiszen a kor előrehaladtával a betegségek előfordulása fokozott, és különösen jellemző erre a populációra a krónikus betegségek együttes jelenléte, a komorbiditás, amelynek viszont szükségszerű következménye több hatóanyag valós indikáción alapuló alkalmazása, azaz a polypharmatia. A halmozott gyógyszerszedés definíciójának többféle megközelítése létezik, a legismertebb a mennyiségi szemlélet, miszerint öt vagy több gyógyszer krónikus együttes alkalmazása polypharmatiának minősül [13]. Érdemes megemlítenünk azonban a klinikai aspektus definícióját is: polypharmatia minden klinikailag nem indokolt vagy szükségtelenül rendelt akár egyetlen szer használata, illetve önmagában csak mellékhatás-kezelésre alkalmazott további gyógyszer adása [13].

Az Amerikai Egyesült Államokban az idősek (>65 év) 57\%-a szed öt gyógyszernél többet tartósan, párhuzamosan [14]. Egy nyolc országra kiterjedő, 2707 személyt felölelő európai tanulmányban pedig az idősek 51\%-ánál találták hat vagy több gyógyszer egy időben történő alkalmazását [12]. Saját felméréseink szerint, a halmozott gyógyszerszedés a mindennapi gyakorlat során az előbbihez hasonló mértékben van jelen hazánkban is $[13,15]$. A polypharmatia növeli az interakciók és a nemkívánatos gyógyszerhatások kialakulásának esélyét, csökkenhet a beteg-együttmúködés, romlik az életminőség és jelentős anyagi megterhelést jelent mind a beteg, mind pedig a társadalom számára A jól ismert matematikai képlettel számolva $\left(\frac{\mathrm{n} \times(\mathrm{n}-1)}{2}\right)$, két gyógyszer együttes alkalmazása esetén egy interakció, öt esetén tíz, 10 gyógyszer esetén pedig már elméletileg 45 interakció lehetséges. Szerencsére a gyakorlatban a lehetséges interakcióknak csak töredéke következik be vagy vezet klinikailag releváns tünethez-tünetekhez.

\section{Potenciálisan nem megfelelő gyógyszerelés időskorban}

Az idős betegek gyógyszeralkalmazásából eredő problémáinak csökkentése érdekében születtek meg azok az ajánlások, amelyek a számukra potenciálisan veszélyt jelentő gyógyszeres terápiákat írják le. Feltételesen nem megfelelő gyógyszereknek (potentially inappropriate medications - PIM) tekintjük azokat a szereket, amelyek alkalmazásának kockázata meghaladja a várható kli- 
nikai előnyt, amennyiben azokat idős betegeknél alkalmazzák és nem helyettesíthetők más, jobban tolerálható szerekkel [16]. Ilyen kockázat például az antikolinerg hatás/mellékhatás, amely a beteg mozgási bizonytalanságához, szédüléséhez, ataxiához, végső soron eleséséhez vezethet.

Az ajánlások közül a legismertebb a Beers-lista, amelyet először 1991-ben az amerikai egyesült államokbeli idősotthonokban lakók számára fejlesztettek ki, de később bármilyen körülmények között élő idős populációra is kiterjesztették. Ennek szükségességét, hasznosságát mi sem bizonyítja jobban, minthogy elsố megjelenése óta három revízión esett át, a legfrissebb elérhető listát idén, 2012-ben tették közzé $[17,18$, 19, 20].

Beers MH 1991-es szempontjai nem vették tekintetbe az alkalmazott gyógyszer dózisát és adagolási módját vagy a fennáló betegségeket, a hatóanyagokat kizárólag farmakológiai szempontok szerint elemezve fogalmazott meg explicit kritériumokat. A 2012-es változat már az Amerikai Geriátriai Társaság interdiszciplináris szakértői csoport konszenzusával készült el, és az alábbi megfontolások szerint került fel egy-egy hatóanyag a listára:

1. A gyógyszer vagy gyógyszercsoport alkalmazása általában kerülendő, mert a szer hatástalan, vagy indokolatlanul magas kockázatot jelent időseknél.

2. A dózis és az adagolás, a kezelési időtartam döntően befolyásolja a szer idősekre való hatását.

3. Egyes gyógyszerek alkalmazása nem javallott bizonyos betegségek fennállásakor (például veseelégtelenség, májelégtelenség) annak ellenére, hogy használatuk az általános idős népesség körében elfogadott [20]

Ebben az ajánlásban tehát nemcsak a nemkívánatos hatással, illetve mellékhatással rendelkező aktív hatóanyagok szerepelnek, hanem azok is, amelyek 65 év felett például csak megfelelő vérszint-monitorozás mellett adhatók.

Idős betegek részére történő új gyógyszer választásánál tehát a fentiek figyelembevétele kívánatos, de a már hosszabb ideje, tartósan alkalmazott gyógyszerek időnkénti felülvizsgálata is javasolt, hiszen - pontosan a fent említett tényezők miatt - előfordulhat, hogy a korábban jól tolerált, bevált gyógyszerét már nem képes metabolizálni a beteg, ekkor dóziscsökkentés vagy szükség esetén gyógyszercsere lehet a megoldás.

A Beers-kritériumok nyomán több ország is megalkotta saját, nemzeti listáját, amely az adott ország gyógyszerkincséhez igazodik [21, 22, 23], így például a legújabbak és földrajzilag hozzánk közel eső területeken kidolgozottak és későbbiekben részletesebben elemzettek: a francia Laroche-lista, a német PRISCUS és végül a Mann-féle osztrák lista [16, 24, 25].

\section{PIM-listák kidolgozásának módszere}

A Beers-listák, valamint a későbbiekben figyelembe vett utóbbi európai ajánlások összeállítása széles körű iroda- lomkutatást követően úgynevezett Delphi-módszerrel történt.

A Delphi-módszert az Amerikai Egyesült Államokban (Rand Corporation) dolgozták ki az 1950-es években, szakértői konszenzus optimalizálása érdekében. A módszer többszintű, többkörü szakértői lekérdezé sen alapul. Első lépése a témának megfelelő strukturált kérdőív kidolgozása, amelyet a vizsgálni kívánt terület szakértőihez juttatnak el. A visszaküldött válaszokat összesítik és a második/többedik kérdezés során a szakértők az előző „kör” véleménymegoszlásainak ismeretében válaszolnak újra, alakítják véleményüket: azaz visszacsatolásként folyamatosan pontos képet kapnak az előző adatfelvétel eredményeiről. A szakértői vélemények összegyújtése természetesen névtelenül történik. A munka tehát több lépcsőben addig folytatódik, amíg az előre meghatározott egyetértési szintű megoldás megszületik $[26,27]$. A módszer viszonylag hoszszadalmas lehet, viszont hatalmas előnye, hogy az illetékes szakértők konszenzusával zárul.

\section{Hazai gyógyszerkincs szürése PIM-szempontok szerint}

Amint már hangsúlyoztuk, az első Beers-lista megalkotása kétség kívül hiánypótló, úttörő munka volt, ám számos probléma is megfogalmazódott általános használhatóságát illetően [28]:

- a listán szereplő gyógyszerek nagy százaléka csak az Amerikai Egyesült Államokban van, illetve volt forgalomban;

- nem strukturált, a rutin klinikai gyakorlatban nem alkalmazták;

- nem értékelték ki a szempontrendszer értékét a nemkívánatos gyógyszerhatások, valamint az egészségügyi költségcsökkentés tekintetében.

A követő, később összeállított ajánlások, listák már a fenti hiányosságok kiküszöbölésére törekedve készültek el. A 2007-es Laroche-lista figyelembe veszi a dózisokat és adagolási módot, illetve az adott hatóanyag elkerülésének javaslatát indoklással is alátámasztja, így a gyakorlatban jobban használható [24, 25]. Új megközelítés volt még az egyes betegcsoportok (magas vérnyomás, veseelégtelenség, hyperlipidaemia stb.) kiemelése, azaz gyógyszerajánlás betegségspecifikus megközelítése. Például a listán veseelégtelen idős beteg számára ellenjavallt gyógyszer megfelelő vesemúködésű idős betegnek rendelhető, ezt a lista egyértelműen jelzi. A Laroche-lista számos esetben még alternatív terápiás javaslatot is tartalmaz. A 2010-es PRISCUS és a 2011-es osztrák lista is minden fent felsorolt szempont figyelembevételével, a nemzeti terápiás gyakorlatnak megfelelően és gyógyszerválasztékhoz igazodva készült el [16, 24]. Tény, hogy amint már fentebb említettük, a 2012-es Beerslistát is ez a multifaktoriális megközelítés jellemzi. 


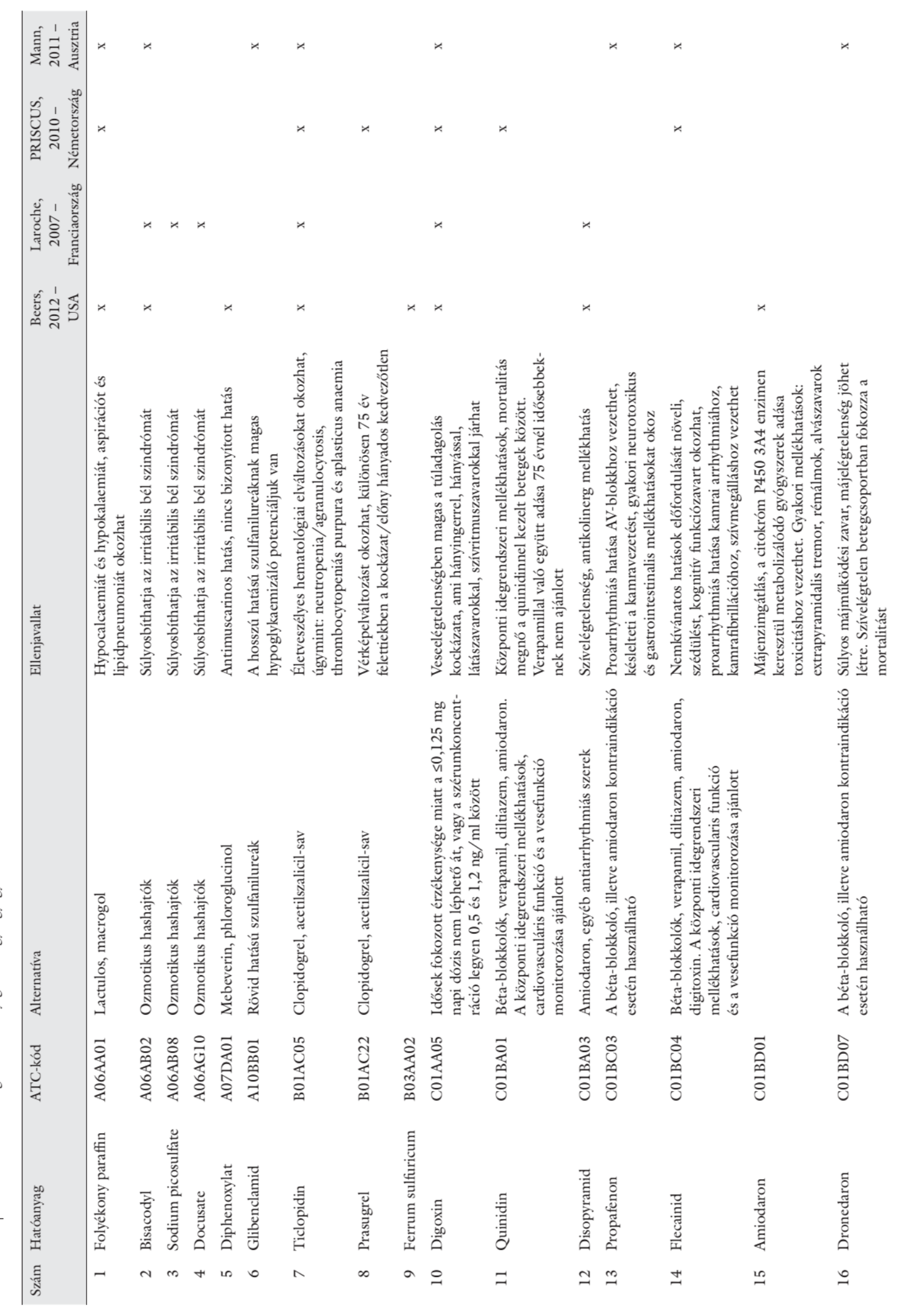




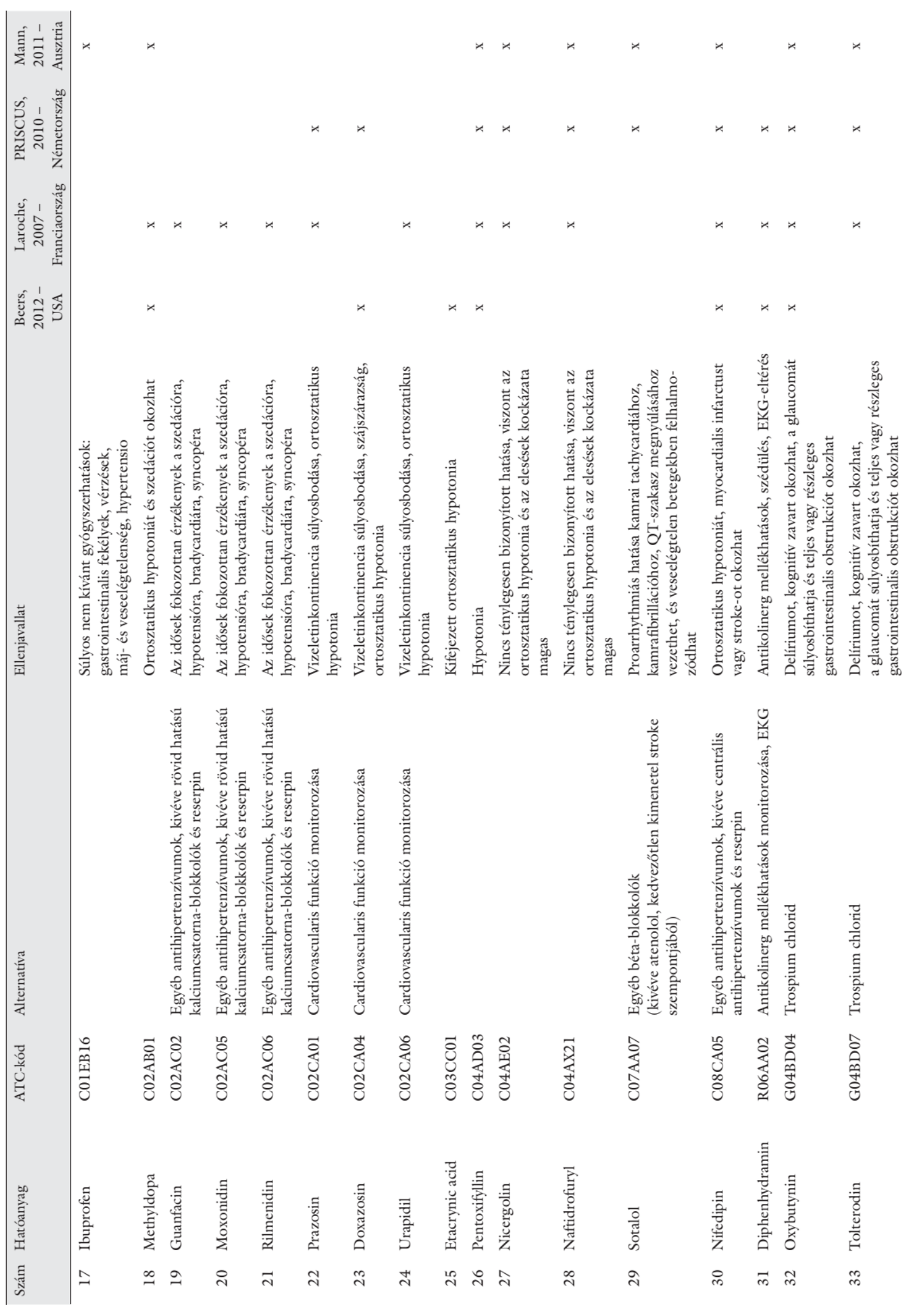




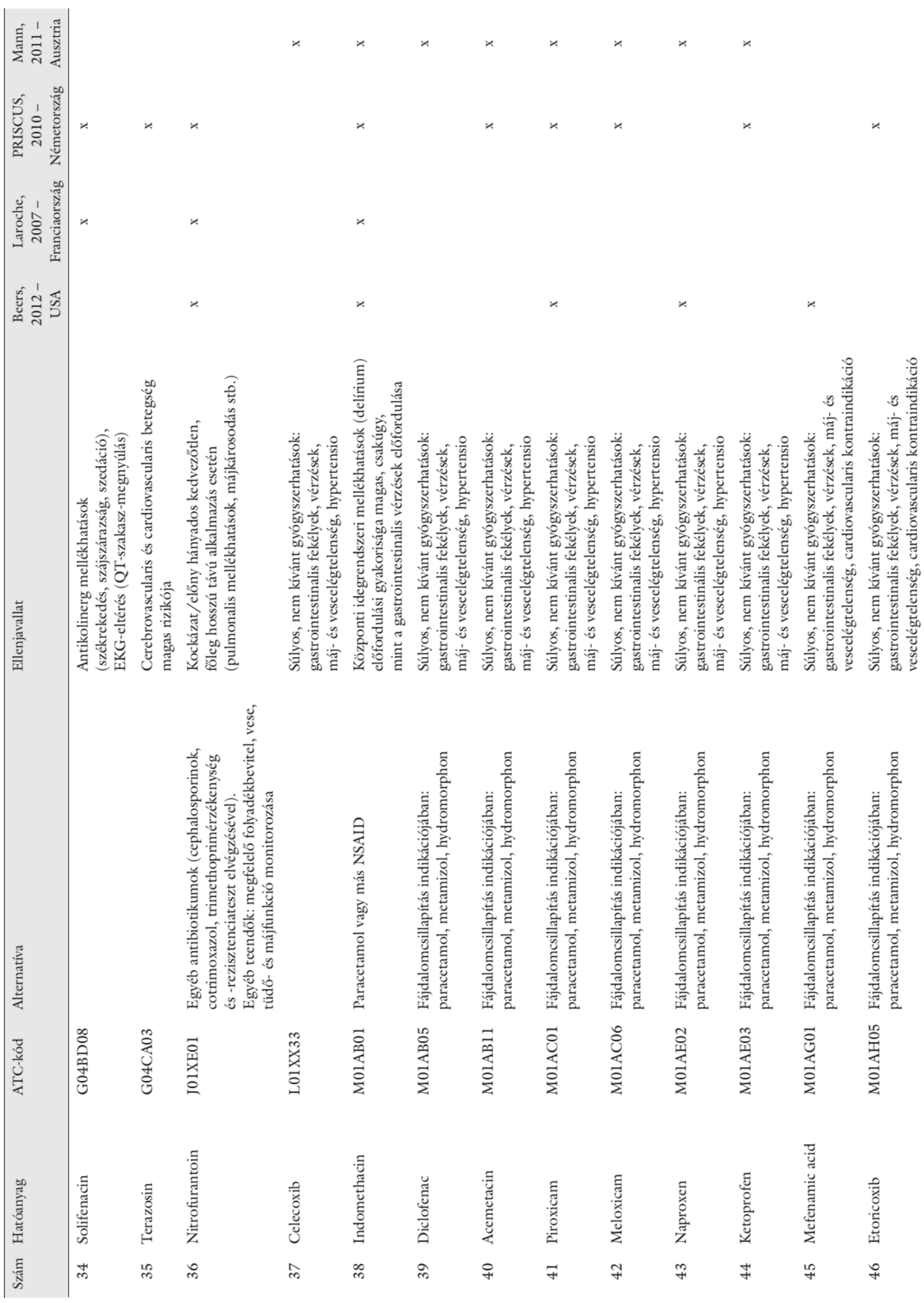




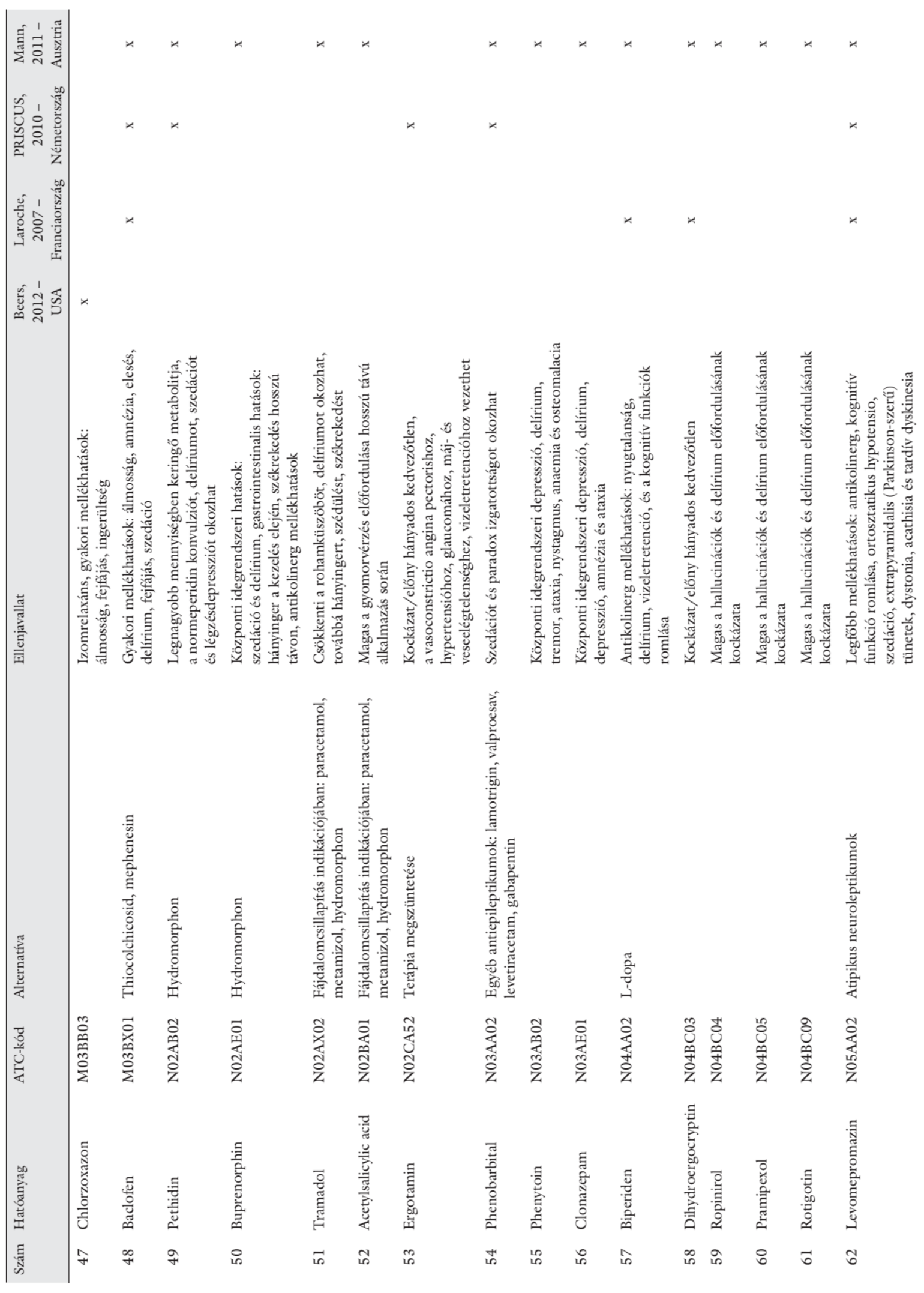




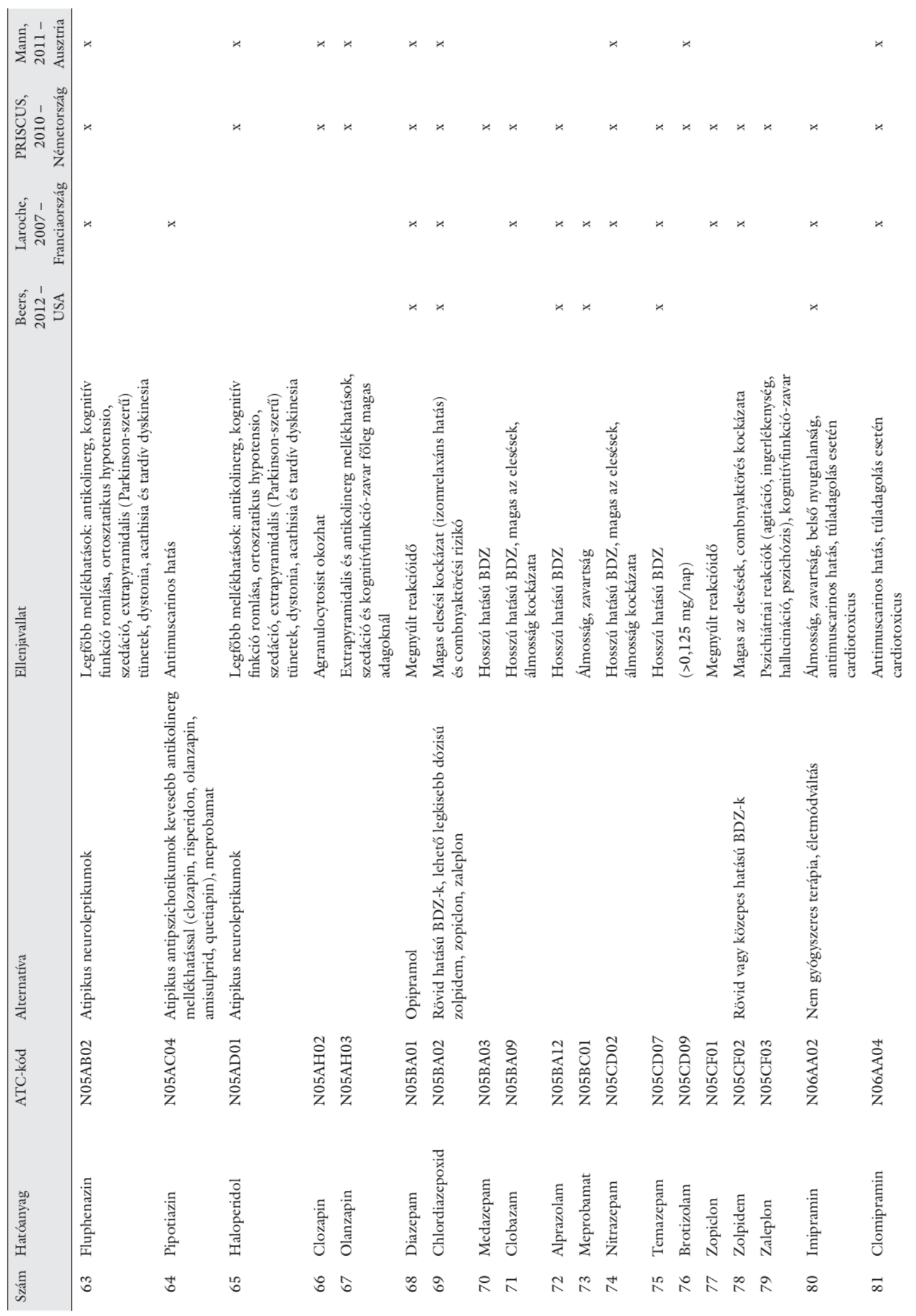




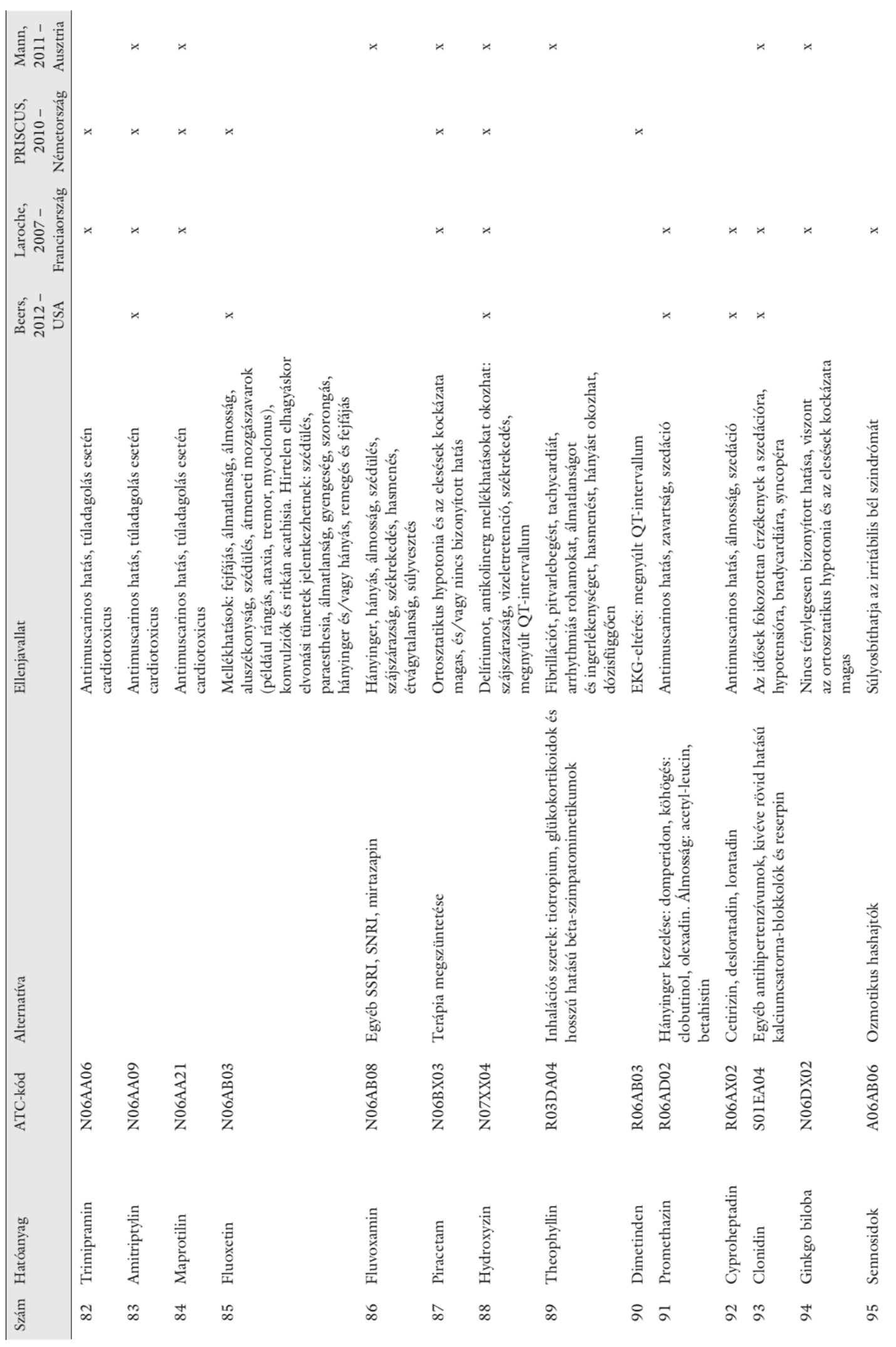


A hazai demográfiai helyzet és a gyógyszerfogyasztási mutatók alapján jutottunk arra az elhatározásra, hogy a hosszadalmas Delphi-módszer nélkül, a hazai gyógyszerkincsre adaptálva a már publikált PIM-listák szintézisét végezzük el. A 2012-es Beers-lista mint „gold standard" mellett, tekintetbe véve az amerikai és európai különbséget, a hozzánk közel álló francia, német és a legújabb osztrák ajánlásokat foglaljuk össze.

Az 1. táblázat összesen 95, hazánkban forgalmazott hatóanyagot tartalmaz, amely az elemzett listák valamelyikén szerepel. Az indikáció meghatározásában a hazai gyakorlatban általánosan alkalmazott ATC-kódok nyújtanak segítséget (az eredeti idegen nyelvű listák ATC-kódot nem tartalmaznak). Minden hatóanyag mellett megtalálható az indoklás, ami alapján felkerül a listára, valamint az ajánlott alternatív gyógyszeres terápia is feltüntetésre került, amennyiben ez elérhetó volt az eredeti listák valamelyikében.

$\mathrm{Az}$ 1. táblázat adatai, az eltérő ajánlások jól tükrözik a nemzeti terápiás gyakorlatok változatosságát. A 95 hatóanyag közül mindössze nyolcat tekint mind a négy lista PIM-nek, azaz ezek vonatkozásában mondható ki a teljes mértékű nemzetközi konszenzus:

Ticlopidin: életveszélyes hematológiai eltéréseket okozhat.

Digoxin: az idősek fokozott érzékenysége miatt a maximált napi adag $0,125 \mathrm{mg}$.

Nifedipin: nem retardált típusú készítmény esetén az ortosztatikus vérnyomás esésének veszélye fokozott.

Pentoxifyllin: hypotonia veszélye.

Oxybutynin: delíriumot, kognitív zavart, részleges vagy teljes gastrointestinalis obstrukciót okozhat és súlyosbíthatja a glaucomát.

Indomethacin: súlyos gastrointestinalis mellékhatása mellett még kifejezett központi idegrendszeri tünetet, delíriumot okozhat.

Diazepam: elhúzódó szedatív hatás, mozgásbizonytalanság.

Amitriptylin: kifejezett antimuscarin hatása miatt túladagolás esetén cardiotoxicitas veszélye kifejezett.

Amennyiben az egyes ajánlásokban szereplő hatóanyagok számát tekintjük, elmondható, hogy a legszigorúbb az osztrák javaslat 56 PIM-hatóanyaggal, ezt követi a PRISCUS lista 53 , majd a Laroche-lista 48 potenciálisan veszélyes hatóanyaggal. A Beers-kritériumok szerint csak 33, idősek számára potenciális veszélyt jelentő hatóanyag van jelen a magyar gyógyszerpiacon. Meg kell ugyanakkor jegyeznünk, hogy hat olyan hatóanyag van, amely viszont kizárólag a Beers-listán szerepel: diphenoxylat, ferrum sulfuricum, etacrynic acid, amiodaron, mefenamic acid, chlorzoxazon (1. táblázat).

\section{Következtetések}

Tagadhatatlan tény, hogy a várható élettartam folyamatos növekedésében a gyógyszeres terápiás lehetőségek elmúlt 50 év során bekövetkezett fejlődése meghatározó jelentőségű, de az utóbbi két évtizedben az is nyilvánvalóvá vált, hogy a pozitív lehetőségek mellett a negatívumok, a potenciális veszélyek is szinte szükségszerű velejárói a gyógyszerek alkalmazásának. Különösen igaz ez az idős személyekre, akiknél sajnálatosan egyidejűleg már több funkciózavar, betegség áll fenn. Esetükben gyakorlatilag elkerülhetetlen a halmozott gyógyszerszedés, amely hatványozott gondokhoz vezethet, figyelembe véve a kronologikus öregedésbő származó természetes fiziológiás változásokat is. Ezen fiziológiás/patofiziológás változások következtében bizonyos gyógyszerek alkalmazása alapvető farmakológiai hatásaikkal összhangban álló, de fokozott klinikai reakciókhoz, nemkívánatos tünetekhez vezethet. Az összegyúlt klinikai tapasztalatok birtokában, összegzésével születtek meg az időskori gyógyszeralkalmazásra vonatkozó, potenciálisan veszélyes hatóanyaglisták és ajánlások a feltételes veszélyek elkerülésére, minimalizálására. Hangsúlyozandó a veszélyek feltételes jellege, azaz szerencsés esetben, individuálisan a baj megjelenésének elmaradása, de ennek tudatában is hangsúlyozandó, hogy a gerontológiai gyógyszerrendelés minőségi (hatóanyag-választás) és mennyiségi (dózis és hatóanyagszám) vonatkozásban egyaránt speciális figyelmet követel.

\section{Köszönetnyilvánítás}

A tanulmány a TÁMOP 4.2.2/B-10/1-2010-0012 számú pályázati keret támogatásával valósult meg.

\section{Irodalom}

[1] Population Division of the United Nations Department of Economic and Social Affairs of the United Nations Secretariat: 2008 Revision of the World Population Prospects. The official website of the United Nations Organization: http://esa.un.org/unpp (Accessed on June 23, 2012)

[2] Ageing characterises the demographic perspectives of the European societies - Issue number $72 / 2008$, The official website of the Eurostat: http://epp.eurostat.ec.europa.eu/ cache/ity_offpub/ks-sf-08-072/en/ks-sf-08-072-en.pdf (Accessed on June 23,2012 )

[3] Monostori, J., Öri, P. S., Molnár, E., et al.: Demographic portrait 2009. State Report from the Hungarian population. [Demográfiai portré, 2009. Jelentés a magyar népesség helyzetéről.] KSH Népességtudományi Kutató Intézet, Budapest, 2009. ISSN 2061 3741. [Hungarian]

[4] The official website of the Nation Master: http://www.nationmaster. com/red/graph/hea_lif_exp_at_bir_tot_pop-life-expectancy-birthtotal-population\&b_printable=1 (Accessed on April 29, 2012

[5] The official website of the World Health Organisation: http:// apps.who.int/gho/indicatorregistry/App_Main/view_indicator. aspx?iid=65 (Accessed on April 29, 2012)

[6] Hartholt, K. A., van der Velde, N., Looman, C. W., et al.: Trends in fall-related hospital admissions in older persons in the Netherlands. Arch. Intern. Med., 2010, 170, 905-911.

[7] Solomon, D. H., Avorn, J., Katz, J. N., et al.: Compliance with osteoporosis medications. Arch. Intern. Med., 2005, 165, 24142419. 
[8] Németh, E. (ed.): Hungary in numbers 2009. [Magyarország számokban - 2009] A Központi Statisztikai Hivatal kiadványa, 2010, www.ksh.hu (Accessed on June 21, 2011) [Hungarian]

[9] Beers, M. H.: Explicit criteria for determining potentially inappropriate medication use by the elderly: An update. Arch. Intern. Med., 1997, 157, 1531-1536.

[10] Fischer, M., Lakatos, P.: The study of vitamin D supply among people over 65. [A D-vitamin-ellátottság vizsgálata 65 év felettiek körében.] Ca és Csont, 2000, 3, 22-24. [Hungarian]

[11] Looker, A. C., Pfeiffer, C. M., Lacher, D. A., et al.: Serum 25-hydroxyvitamin D status of the US population: 1988-1994 compared with 2000-2004. Am. J. Clin. Nutr., 2008, 88, 1519 1527.

[12] Fialová, D., Topinková, E., Gambassi, G., et al.: Potentially inappropriate medication use among elderly home care patients in Europe. JAMA, 2005, 293, 1348-1358.

[13] Viola, R., Csukonyi, K., Doró, P., et al.: Reason for polypharmacy among psychiatric patients. Pharm. World Sci., 2004, 26, 143-147.

[14] Hajjar, E. R., Cafiero, A. C., Hanlon, J. T.: Polypharmacy in elderly patients. Am. J. Geriatr. Pharmacother., 2007, 5, 345-351.

[15] Megyesi, K., Matuz, M., Benkô, R., et al.: Potentially inappropriate prescribing for the elderly. Pharmacoepidemiol. Drug Saf., 2008, 17 (Suppl. 1), 147-148.

[16] Holt, S., Schmiedl, S., Thürmann, P.: Potentially inappropriate medications in the elderly: The PRISCUS list. Dtsch. Arztebl. Int., 2010, 107, 543-551.

[17] Beers, M. H., Ouslander, J. G., Rollingher, I., et al.: Explicit criteria for determining inappropriate medication use in nursing homes. Arch. Intern. Med., 1991, 151, 1825-1832.

[18] Beers, M. H., Ouslander, J. G., Rollingher, I., et al.: Inappropriate medication prescribing in skilled nursing facilities. Ann. Intern. Med., 1992, 117, 684-689.

[19] Donna, M., Fick, R. N., Cooper, J. W., et al.: Updating the Beers criteria for potentially inappropriate medication use in older adults: Results of a US Consensus Panel of Experts. Arch. Intern. Med., 2003, 163, 2716-2724.
[20] The American Geriatrics Society 2012 Beers Criteria Update Expert Panel: American Geriatrics Society updated Beers criteria for potentially inappropriate medication use in older adults J. Am. Geriatr. Soc., 2012, 60, 616-631.

[21] McLeod, P. J., Huang, A. R., Tamblyn, R. M., et al.: Defining inappropriate practices in prescribing for elderly people: a national consensus panel. CMAJ, 1997, 156, 385-391.

[22] Hanlon, J. T., Schmader, K. E., Samsa, G. P., et al.: A method for assessing drug therapy appropriateness. J. Clin. Epidemiol., 1992, 45, 1045-1051.

[23] Gallagher, P., O'Mahoney, D.: STOPP (Screening tool of older persons' potentially inappropiate prescription) application to patients and comparison with Beers' criteria. Age and Ageing, 2008, 37, 673-679.

[24] Laroche, M. L., Charmes, J. P., Merle, L.: Potentially inappropriate medications in the elderly: a French consensus panel list. Eur. J. Clin. Pharmacol., 2007, 63, 725-731.

[25] Mann, E., Böhmdorfer, B., Frühwald, T., et al.: Potentially inap propriate medication in geriatric patients: the Austrian consensus panel list. Wien. Klin. Wochenschr., 2012, 124, 160-169.

[26] Linstone, H. A., Turoff, M.: The Delphi method: Techniques and applications, reading, mass. Addison-Wesley, 1975, ISBN 978-0-201-04294-8

[27] Rowe, G., Wright, G.: The Delphi technique as a forecasting tool: issues and analysis. International Journal of Forecasting, $1999,15,353-375$

[28] O'Mahony, D.: Inappropiate prescribing in older people - lecture. Brit. Geriat. Society Autumn Meeting, 2010.

\section{Meghívó}

\section{„Kérdőjelek a gasztroenterológiában"}

a Szent János Kórház I. Belgyógyászati és Gasztroenterológiai Osztálya a Magyar Gasztroenterológiai Társaság és a Magyar Ultrahang Társaság tudományos ülése

Időpont: 2012. december 6. (csütörtök) 14 óra

Helyszín: Szent János Kórház Auditóriuma - 1125 Budapest, Diósárok u. 1-3.

Üléselnök: Prof. Dr. Nemesánszky Elemér és Dr. Székely György

Előadások: Dr. Siket Ferenc: Hol kezeljük, mikor endoszkópizáljuk a gastrointestinalis vérző beteget?

Dr. Szilvás Ágnes: Kapszulás endoszkópia: csak vékonybélvérzés esetén?

Dr. Pusztay Margit: Krónikus hepatitisben indokolt-e a májrák szürése?

Dr. Bóka Béla: Nyelöcsővarix-vérzés: el kell-e idáig jutnunk?

Dr. Székely György: Irritábilis bél szindróma: pszichés vagy organikus betegség? Vita

Minden érdeklődőt szeretettel várunk.

A Semmelweis Egyetem által akkreditált rendezvény. 
IV. 


\title{
Idősek gyógyszerelése: kockázatot jelentő hatóanyagok
}

\author{
Bor Andrea, Matuz Mária, Doró Péter, Soós Gyöngyvér
}

\begin{abstract}
Elöszó
$\mathrm{Az}$ Emberi Erőforrások Minisztériuma Egészségügyért Felelős Államtitkárság a gyógyszertáraknak nyújtandó szolgáltatási díjhoz kapcsolódó jogszabálymódosítások keretei között döntött a „több mint 5 gyógyszert szedő, 62 év feletti betegekhez kapcsolódó emelt szintü gyógyszerészi gondozási tevékenység" bevezetéséről. A döntés értelmében - ha a gyógyszertár „emelt szintű gyógyszerészi gondozás” végzésére alkalmas és felhatalmazott - a gyógyszerésznek 2013. július elsejétől a patikába betérő idős betegek gyógyszerelésének teljes és körültekintő időszakos áttekintését el kell végeznie. ${ }^{1}$ Bízunk benne, hogy közleményünk hozzájárulhat ahhoz, hogy ennek a kihívásnak gyakorló kollégáink minél nagyobb számban eleget tudnak majd tenni.
\end{abstract}

\section{Bevezetés}

Általános tapasztalat szerint a gyógyszerhasználat folyamatos növekedésének sajnálatos velejárója a gyógyszerekkel kapcsolatos gondok (Drug-Related Problems - DRP) szaporodása. A gyógyszeralkalmazáshoz kapcsolódó, ám speciális gondoskodással csökkenthető problémák túlnyomóan az idős betegeket érintik, mivel a rendszeres, krónikus gyógyszerfogyasztók döntően az idős, 65 év feletti személyek közül kerülnek ki. Számos esetben az egyidejüleg fennálló különböző betegségek, comorbiditások indokolják ugyan többféle gyógyszer párhuzamos rendelését, de a szükséges hatóanyagok, adagok, az alkalmazási mód és időtartam meghatározása megkülönböztetett figyelmet kíván. A gerontológiai gyógyszerelés általános nehézségeit és a potenciálisan problémás gyógyszereket foglalja össze közleményünk.

\section{Demográfiai háttér}

A társadalom elöregedése napjainkban a fejlett országokban - így hazánkban is - megfigyelhető, jól dokumentált jelenség. Magyarországon nemcsak az idős lakosság aránya növekszik, hanem a társadalom öregedésének üteme is gyorsul. Míg a KSH adatai szerint

\footnotetext{
${ }^{1}$ A szabályozás részleteinek kidolgozására a július 1-jét megelőzó időszakban kerül sor.
}

2010-ben $17 \%$ körüli volt a 65 éven felüliek aránya hazánkban, addig az Európai Statisztikai Hivatal becslései szerint ez az arány 2060-ra akár a 32\%-ot is elérheti $[1,2,3]$. Ennek hátterében föként az alacsony születésszám és az élettartam várható meghosszabbodása állhat. A Világbank és a WHO egybehangzó adatai szerint 2010-ben a születéskor várható élettartam Magyarországon 70,5 év a férfiak, és 78,1 év a nők körében, átlagosan 74,2 év. Bár a várható élettartam folyamatosan növekvő tendenciát mutat, más fejlett országokhoz viszonyítva (pl. Németország, Ausztria, Csehország, Horvátország, Szlovákia) hazánk még mindig sereghajtó $[4,5]$.

\section{Halmozott gyógyszerszedés}

$\mathrm{Az}$ öregedés tényének jelentős egészségügyi vonatkozása van, hiszen a kor elörehaladtával a betegségek előfordulása gyakoribb, és különösen jellemző erre a populációra a comorbiditás, a krónikus betegségek együttes jelenléte, amelynek viszont szükségszerű következménye több hatóanyag valós indikáción alapuló alkalmazása, azaz a polifarmácia. A halmozott gyógyszerszedés definíciójának többféle megközelítése létezik. Legismertebb a mennyiségi szemlélet, miszerint 5 vagy több gyógyszer krónikus együtt alkalmazása polifarmáciának minősül [6]. Érdemes megemlítenünk azonban a klinikai aspektus definícióját is: polifarmácia minden klinikailag nem indokolt, vagy akár egyetlen szükségtelenül rendelt szer használata, illetve önmagában csak mellékhatás kezelésre alkalmazott további gyógyszer adása [6].

Egy 2007-ben, az Amerikai Gerontológiai Szaklapban közölt kutatás eredménye szerint az Amerikai Egyesült Államokban az idősek (>65 év) 57\%-a szed 5 gyógyszernél többet tartósan, párhuzamosan [7]. Egy 8 országra kiterjedő, 2707 személyt felölelő, 2005-ben megjelent európai tanulmányban pedig idősek 51\%ánál találták 6 vagy több gyógyszer egy időben történő alkalmazását [8]. Saját felméréseink szerint, a halmozott gyógyszerszedés a mindennapi gyakorlat során az előbbihez hasonló mértékben van jelen hazánkban is $[6,9]$. A polifarmácia növeli az interakciók és a nem kívánatos gyógyszerhatások kialakulásának esélyét, csökkenhet a beteg együttműködés, romlik az életminőség és jelentős anyagi megterhelést jelent mind a beteg, mind pedig a társadalom számára. Hogy 
az interakciókkal kapcsolatos várható kockázatot konkrét számokkal is szemléltessük, a jól ismert matematikai képlettel számolva $\left(\frac{n \cdot(n-1)}{2}\right)$ két gyógyszer együttes alkalmazása esetén egy interakció, 5 esetén tíz, 10 gyógyszer esetén pedig már elméletileg negyvenöt interakció kialakulása lehetséges. Szerencsére a gyakorlatban a lehetséges interakcióknak csak töredéke következik be, vagy vezet klinikailag releváns tünetekhez.

\section{Potenciálisan nem megfelelö gyógyszerelés idös korban}

Az idős betegek gyógyszeralkalmazásából eredő problémák csökkentése érdekében születtek meg azok az ajánlások, amelyek a számukra potenciálisan veszélyt jelentő gyógyszeres terápiákat rögzítik. Feltételesen nem megfelelő gyógyszereknek (Potentially Inappropriate Medications - PIM) tekintjük azokat a szereket, amelyek alkalmazásának kockázata meghaladja a várható klinikai előnyt, amennyiben azokat idős betegeknél alkalmazzák és nem helyettesíthetök más, jobban tolerálható szerekkel [10]. Ilyen kockázat például az anticholinerg hatás/mellékhatás, mely a beteg mozgási bizonytalanságához, szédüléséhez, ataxiához, végső soron eleséséhez vezethet.

Az ajánlások közül a legismertebb az ún. Beers lista, amelyet először 1991-ben az USA-beli idősotthonok lakói számára fejlesztettek ki, majd ezt kiterjesztették bármilyen körülmények között élő idős populációra. Ennek szükségességét, hasznosságát mi sem bizonyítja jobban, minthogy első megjelenése óta 3 revízión esett át, a legfrissebb elérhető listát tavaly, 2012-ben tették közzé [11, 12, 13, 14].

Mark H. Beers 1991-es szempontjainak összeállításakor nem vette tekintetbe az esetlegesen fennálló betegségeket, az alkalmazott gyógyszer dózisát vagy adagolási módját. A hatóanyagokat kizárólag farmakológiai szempontok szerint elemezte, és ennek alapján fogalmazott meg explicit kritériumokat. A 2012-es változat már az Amerikai Geriátriai Társaság interdiszciplináris szakértői csoportjának konszenzusával készült el, és az alábbi megfontolások szerint került fel egy-egy hatóanyag a listára:

- a gyógyszer vagy gyógyszercsoport alkalmazása általában kerülendő, mert a szer hatástalan, vagy indokolatlanul magas kockázatot jelent időseknél;

- a dózis, az adagolási mód, a kezelési időtartam döntően befolyásolja a szer idősekre való hatását;

- a gyógyszer alkalmazása nem javallott bizonyos betegségek fennállásakor ( $\mathrm{pl}$. veseelégtelenség, májelégtelenség) annak ellenére, hogy használata az általános idős népesség körében elfogadott [14].

Ebben az ajánlásban tehát nem ,pusztán” a nemkívánatos hatással, ill. mellékhatással rendelkező aktív hatóanyagok szerepelnek, hanem olyanok is, melyek
65 év felett például csak megfelelő vérszint-monitorozás mellett adhatók. Idős betegek részére új gyógyszer választásánál tehát a fentiek figyelembe vétele kívánatos, de a már hosszabb ideje, tartósan alkalmazott gyógyszerek időnkénti felülvizsgálata is javasolt, hiszen - pontosan a fent említett tényezők miatt - elöfordulhat, hogy a beteg a korábban jól tolerált gyógyszerét már nem képes metabolizálni. Ekkor dóziscsökkentés vagy szükség esetén gyógyszercsere lehet a megoldás.

A Beers kritériumok nyomán több ország is megalkotta saját nemzeti listáját, mely az adott ország gyógyszerkincséhez igazodik [15, 16, 17]. Így például a legújabbak és földrajzilag hozzánk közel eső területeken kidolgozottak: a francia Laroche, a német Priscus, és végül a Mann-féle osztrák lista, melyeket a későbbiekben részletesebben is elemzünk [10, 18, 19].

\section{PIM listák kidolgozásának módszere}

A Beers listák, valamint a későbbiekben figyelembe vett utóbbi európai ajánlások összeállítása széleskörü irodalomkutatást követően ún. Delphi módszerrel történt. A Delphi módszert az Amerikai Egyesült Államokban (Rand Corporation) dolgozták ki az 1950-es években, szakértői konszenzus optimalizálása érdekében. A módszer első lépése a témának megfelelő strukturált kérdőív kidolgozása, amelyet a vizsgálni kívánt terület szakértőihez juttatnak el. A visszaküldött válaszokat összesítik és a második/többedik kérdezés során a szakértők az előző „kör” vélemény-megoszlásainak ismeretében válaszolnak újra, természetesen névtelenül. A munka több lépcsőben addig folytatódik, amíg az előre meghatározott egyetértési szintü megoldás megszületik [20, 21]. A módszer viszonylag hosszadalmas lehet, viszont hatalmas előnye, hogy az illetékes szakértők konszenzusával zárul.

\section{A PIM kritériumok gyakorlati alkalmazhatósága}

Amint már hangsúlyoztuk, az első Beers lista megalkotása kétség kívül hiánypótló, úttörő munka volt, ám számos probléma is megfogalmazódott az általános használhatóságát illetően [22]. Széleskörü elterjedését limitálta, hogy a listán szereplő gyógyszerek nagy százaléka kizárólag az Amerikai Egyesült Államokban van, illetve volt forgalomban. A rutin klinikai gyakorlatban való alkalmazásának korlátot szabott a lista strukturáltságának hiánya, továbbá a szempontrendszert a nemkívánatos gyógyszerhatások valamint az egészségügyi költségcsökkentés tekintetében sem értékelték ki.

A később összeállított ajánlások, nemzeti listák már a fenti hiányosságok kiküszöbölésére törekedve készültek el. A 2007-es Laroche lista már figyelembe veszi a dózisokat és adagolási módot, illetve az adott ha- 
Potenciálisan nem megfelelö hatóanyagok a magyar gyógyszerkincsben

\begin{tabular}{|c|c|c|c|}
\hline & Hatóanyag & ATC & Figyelmeztetés \\
\hline 1. & Folyékony paraffin & A06AA01 & Hipocalcaemiát és hypokalaemiát, aspirációt és lipid pneumoniát okozhat \\
\hline 2. & Nátrium pikoszulfát & A06AB08 & Súlyosbíthatja az irritábilis bél szindrómát \\
\hline 3. & Tiklopidin ${ }^{*}$ & B01AC05 & $\begin{array}{l}\text { Életveszélyes hematológiai elváltozásokat okozhat, úgy mint: neutropénia/ } \\
\text { agranulocytosis, thrombocytopenias purpura és aplasticus anaemia }\end{array}$ \\
\hline 4. & Digoxin ${ }^{*}$ & C01AA05 & $\begin{array}{l}\text { Veseelégtelenségben magas a túladagolás kockázata, ami hányingerrel, hányás- } \\
\text { sal, látászavarokkal, szívritmus-zavarokkal járhat }\end{array}$ \\
\hline 5. & Propafenon & $\mathrm{C} 01 \mathrm{BC} 03$ & $\begin{array}{l}\text { Pro-arrithmiás hatása AV-blokkhoz vezethet, késlelteti a kamravezetést, gyakori } \\
\text { neurotoxikus és gastrointestinalis mellékhatásokat okoz }\end{array}$ \\
\hline 6. & Amiodaron & C01BD01 & $\begin{array}{l}\text { Májenzim-gátlás, a citokróm P450 3A4 enzimen keresztül metabolizálódó } \\
\text { gyógyszerek adása toxicitáshoz vezethet. Gyakori mellékhatások: } \\
\text { extrapiramidális tremor, rémálmok, alvászavarok }\end{array}$ \\
\hline 7. & Ibuprofen & C01EB16 & $\begin{array}{l}\text { Súlyos nem kívánt gyógyszerhatások: gastrointestinalis fekélyek, vérzések, máj- } \\
\text { és veseelégtelenség, hypertensio }\end{array}$ \\
\hline 8. & Moxonidin & $\mathrm{C} 02 \mathrm{AC} 05$ & $\begin{array}{l}\text { Idősek fokozottan érzékenyek szedációra, hypotensiora, bradycardiára, } \\
\text { syncopéra }\end{array}$ \\
\hline 9. & Rilmenidin & $\mathrm{C} 02 \mathrm{AC} 06$ & $\begin{array}{l}\text { Idősek fokozottan érzékenyek szedációra, hypotensiora, bradycardiára, } \\
\text { syncopéra }\end{array}$ \\
\hline 10. & Prazosin & C02CA01 & Vizelet-inkontinencia súlyosbodása, orthostaticus hypotonia \\
\hline 11. & Doxazozin & C02CA04 & Vizelet-inkontinencia súlyosbodása, szájszárazság, orthostaticus hypotonia \\
\hline 12. & Pentoxifillin ${ }^{*}$ & C04AD03 & Hypotonia \\
\hline 13. & Nicergolin & C04AE02 & $\begin{array}{l}\text { Nincs ténylegesen bizonyított hatása, viszont az orthostaticus hypotonia és az } \\
\text { elesések kockázata magas }\end{array}$ \\
\hline 14. & Nifedipin* & C08CA05 & Orthostaticus hypotoniát, myocardialis infarctust vagy stroke-ot okozhat \\
\hline 15. & Oxybutinin ${ }^{*}$ & G04BD04 & $\begin{array}{l}\text { Delíriumot, kognitív zavart okozhat, glaukómát súlyosbíthatja és teljes vagy } \\
\text { részleges gastrointestinalis obstrukciót okozhat }\end{array}$ \\
\hline 16. & Celecoxib & M01AH01 & $\begin{array}{l}\text { Súlyos nem kívánt gyógyszerhatások: gastrointestinalis fekélyek, vérzések, máj- } \\
\text { és veseelégtelenség, hypertensio }\end{array}$ \\
\hline 17. & Indometacin ${ }^{*}$ & M01AB01 & $\begin{array}{l}\text { Kp-i idegrendszeri mellékhatások (delírium) előfordulási gyakorisága magas, } \\
\text { csakúgy, mint a gastrointestinalis vérzések előfordulása }\end{array}$ \\
\hline 18. & Diklofenak & M01AB05 & $\begin{array}{l}\text { Súlyos nem kívánt gyógyszerhatások: gastrointestinalis fekélyek, vérzések, máj- } \\
\text { és veseelégtelenség, hypertensio }\end{array}$ \\
\hline 19. & Piroxikam & M01AC01 & $\begin{array}{l}\text { Súlyos nem kívánt gyógyszerhatások: gastrointestinalis fekélyek, vérzések, máj- } \\
\text { és veseelégtelenség, hypertensio }\end{array}$ \\
\hline 20. & Meloxikam & M01AC06 & $\begin{array}{l}\text { Súlyos nem kívánt gyógyszerhatások: gastrointestinalis fekélyek, vérzések, máj- } \\
\text { és veseelégtelenség, hypertensio }\end{array}$ \\
\hline 21. & Naproxen & M01AE02 & $\begin{array}{l}\text { Súlyos nem kívánt gyógyszerhatások: gastrointestinalis fekélyek, vérzések, máj- } \\
\text { és veseelégtelenség, hypertensio }\end{array}$ \\
\hline 22. & Tramadol & N02AX02 & $\begin{array}{l}\text { Csökkenti a rohamküszöböt, delíriumot okozhat, továbbá hányingert, szédülést, } \\
\text { székrekedést }\end{array}$ \\
\hline 23. & Klonazepam & N03AE01 & Kp-i idegrendszeri depresszió, delírium, depresszió, amnézia és ataxia \\
\hline 24. & Olanzapin & N05AH03 & $\begin{array}{l}\text { Extrapiramidális és anticholinerg mellékhatások, szedáció és kognitív funkció } \\
\text { zavar, föleg magas adagoknál }\end{array}$ \\
\hline 25. & Diazepam* & N05BA01 & Megnyúlt reakcióidő \\
\hline 26. & Klordiazepoxid ${ }^{*}$ & N05BA02 & Magas elesési kockázat (izomrelaxáns hatás) és combnyaktörési rizikó \\
\hline 27. & Alprazolam & N05BA12 & Hosszú hatású BDZ \\
\hline 28. & Zopiklon & N05CF01 & Megnyúlt reakcióidő \\
\hline
\end{tabular}




\begin{tabular}{l|l|c|l}
\hline & Hatóanyag & ATC & \multicolumn{1}{c}{ Figyelmeztetés } \\
\hline 29. & Zolpidem & N05CF02 & Magas az elesések, combnyaktörés kockázata \\
\hline 30. & Zaleplon & N05CF03 & $\begin{array}{l}\text { Pszichiátriai reakciók (agitáció, ingerlékenység, hallucináció, psychosis), kogni- } \\
\text { tív funkció zavar }\end{array}$ \\
\hline 31. & Amitriptilin* & N06AA09 & Antimuscarinos hatás, túladagolás esetén cardiotoxikus \\
\hline 32. & Piracetam & N06BX03 & $\begin{array}{l}\text { Orthostaticus hypotonia és az elesések kockázata magas, és/vagy nincs bizonyí- } \\
\text { tott hatás }\end{array}$ \\
\hline 33. & Ginkgo biloba & N06DX02 & $\begin{array}{l}\text { Nincs ténylegesen bizonyított hatása, viszont az orthostaticus hypotonia és az } \\
\text { elesések kockázata magas }\end{array}$ \\
\hline 34. & Hidroxizin* & N07XX04 & $\begin{array}{l}\text { Delíriumot, anticholinerg mellékhatásokat okozhat: szájszárazság, vizeletreten- } \\
\text { ció, székrekedés, megnyúlt QT intervallum }\end{array}$ \\
\hline 35. & Teofillin & R03DA04 & $\begin{array}{l}\text { Fibrillációt, pitvarlebegést, tachycardiát, arrithmiát, álmatlanságot és ingerlé- } \\
\text { kenységet, hasmenést, hányást okozhat, dózisfüggó }\end{array}$ \\
\hline
\end{tabular}

Megjegyzés: * = mind a 4 PIM listán szereplő hatóanyag

tóanyag elkerülésének javaslatát indoklással is alátámasztja, így a gyakorlatban jobban használható $[18$, 19]. Új megközelítés volt még az egyes betegcsoportok (pl. magas vérnyomás, veseelégtelenség, hyperlipidaemia stb.) kiemelése, azaz ilyenkor a gyógyszerajánlás betegség-specifikus megközelítésen alapul. Például veseelégtelenségben szenvedő idős beteg számára ellenjavallt gyógyszer megfelelő vesemüködésü idős betegnek rendelhető, ezt a lista egyértelmüen jelzi. A Laroche lista számos esetben még alternatív terápiás javaslatot is tartalmaz. A 2010-es Priscus, és a 2011-es osztrák Mann-lista is minden fent felsorolt szempont figyelembe vételével, a nemzeti terápiás gyakorlatnak megfelelően és a gyógyszerválasztékhoz igazodva készült el [10, 18]. A legfrissebb, 2012-es Beers listát is ez a multifaktoriális megközelítés jellemzi.

\section{Hazai gyógyszerkincs szürése PIM szempontok szerint}

A hazai demográfiai helyzet és a gyógyszerfogyasztási mutatók alapján jutottunk arra az elhatározásra, hogy a hosszadalmas Delphi módszer nélkül, a hazai gyógyszerkincsre adaptálva végeztük el a már publikált PIM listák szintézisét. A 2012-es Beers', mint „gold standard" mellett - tekintetbe véve az amerikai és európai különbséget - a hozzánk közel álló, francia, német és a legújabb osztrák ajánlásokat foglaljuk össze.

Amennyiben az egyes ajánlásokban szereplő hatóanyagok számát tekintjük, elmondható, hogy a legszigorúbb az osztrák javaslat 56 PIM hatóanyaggal, ezt követi a Priscus lista 53, majd a Laroche 48 potenciálisan veszélyes hatóanyaggal. A Beers' kritériumok szerint csak 33, idősek számára potenciális veszélyt jelentő hatóanyag van jelen a magyar gyógyszerpiacon.

Az eredeti publikáció és a részletes magyar gyógyszerlista az Orvosi Hetilap 153. évfolyam, 49. számában érhető el: „Az időskori gyógyszeralkalmazás problé- mái" címmel². A táblázat összesen 95, hazánkban forgalmazott hatóanyagot tartalmaz, amelyek az elemzett listák valamelyikén szerepelnek. Minden hatóanyag mellett megtalálható az indoklás, ami alapján felkerült a listára, valamint az ajánlott alternatív gyógyszeres terápia is feltüntetésre került, amennyiben ez elérhető volt az eredeti listák valamelyikében. Az indikáció meghatározásában, a hazai gyakorlatban általánosan alkalmazott ATC kódok nyújtanak segítséget (az eredeti idegen nyelvü listák ATC kódot nem tartalmaznak).

Jelen közleményben a 95 hatóanyagból csak 35 hatóanyagot emeltük ki: a Magyarországon leggyakrabban forgalmazottakat, illetve azokat, melyeket mind a négy eredeti idegen nyelvü lista PIM-nek tekintett (I. táblázat). Az eltérő ajánlások jól tükrözik a nemzeti terápiás gyakorlatok változatosságát. A 95 hatóanyag közül mindössze 10-et tekint mind a négy lista PIMnek, azaz ezek vonatkozásában mondható ki a teljes mértékü nemzetközi konszenzus:

- Tiklopidin: életveszélyes hematológiai eltéréseket okozhat;

- Digoxin: az idősek fokozott érzékenysége miatt a maximált napi adag $0,125 \mathrm{mg}$;

- Pentoxifillin: hypotonia veszélye;

- Nifedipin: nem retardált típusú készítmény esetén az orthostaticus vérnyomásesés veszélye fokozott;

- Oxibutinin: delíriumot, kognitív zavart, részleges vagy teljes gastrointestinalis obstrukciót okozhat és súlyosbíthatja a glaucomát;

- Indometacin: súlyos gastrointestinalis mellékhatása mellett még kifejezett központi idegrendszeri tünetet, delíriumot okozhat;

- Diazepam: elhúzódó szedatív hatás, mozgási bizonytalanság;

${ }^{2}$ Bor Andrea, Matuz Mária, Doró Péter, Viola Réka, Soós Gyöngyvér: Az időskori gyógyszeralkalmazás problémái Orv. Hetil., 153, 1926-1936 (2012). 
- Klordiazepoxid: magas elesési kockázat (izomrelaxáns hatás) és combnyaktörési rizikó;

- Amitriptilin: kifejezett antimuscarin hatása miatt túladagolás esetén a cardiotoxicitás veszélye kifejezett:

- Hidroxizin: delíriumot, anticholinerg mellékhatásokat okozhat: szájszárazság, vizeletretenció, székrekedés, megnyúlt QT intervallum.

\section{Következtetések}

Tagadhatatlan tény, hogy a várható élettartam folyamatos növekedésében a gyógyszeres terápiás lehetőségek elmúlt 50 év során bekövetkezett fejlődése meghatározó jelentőségü. Ám az utóbbi két évtizedben az is nyilvánvalóvá vált, hogy a pozitív eredmények mellett a negatívumok, a potenciális veszélyek is szinte szükségszerü velejárói a gyógyszerek alkalmazásának. Különösen igaz ez az idős személyekre, akiknél sajnálatosan egyidejüleg már több funkciózavar, betegség áll fenn. Esetükben gyakorlatilag elkerülhetetlen a halmozott gyógyszerszedés, amely hatványozott gondokhoz vezethet, figyelembe véve a kronologikus öregedésből származó természetes fiziológiás változásokat is. Ezen fiziológiás /patofiziológás változások következtében bizonyos gyógyszerek alkalmazása fokozott klinikai reakciókhoz, nem kívánatos tünetekhez vezethet. Az összegyült klinikai tapasztalatok birtokában, ezek összegzésével születtek meg az időskori gyógyszeralkalmazásra vonatkozó, potenciálisan veszélyes hatóanyag-listák és ajánlások a feltételes veszélyek elkerülésére, minimalizálására. Hangsúlyozandó a veszélyek feltételes jellege, azaz szerencsés esetben, individuálisan a baj megjelenésének elmaradása, de ennek tudatában is kiemelten fontos, hogy a gerontológiai gyógyszerrendelés minőségi (hatóanyag választás) és mennyiségi (dózis és hatóanyag darabszám) vonatkozásban egyaránt speciális figyelmet követel.

\section{IRODALOM}

1. Population Division of the United Nations Department of Economic and Social Affairs of the United Nations Secretariat:
2008 Revision of the World Population Prospects. The official website of the United Nations Organization: http://esa.un.org/ unpp (Letöltve 2012. június 23.) - 2. Ageing characterises the demographic perspectives of the European societies - Issue number 72/2008, The official website of the Eurostat: http:// epp.eurostat.ec.europa.eu/ cache/ity_offpub/ks-sf-08-072/ en/ks-sf-08-072-en.pdf (Letöltve 2012. június 23.) - 3. Monostori, J., Öri, P., S. Molnár, E., et al.: Demográfiai portré 2009. Jelentés a magyar népesség helyzetéről, KSH Népességtudományi Kutató Intézet Budapest 2009, ISSN 2061 3741. - 4. The official website of The World Bank (Letöltve 2013. február 11.) - 5. The official website of the World Health Organisation: http://apps.who.int/gho/ indicatorregistry/ App_Main/view_indicator.aspx?iid=65 (Letöltve 2013. február 11.) - 6. Viola, R., Csukonyi, K., Doró, P., et al.: Pharm. World. Sci., 26, 143-147 (2004). - 7. Hajjar, E.R., Cafiero, A. C., Hanlon, J. T.: Am. J. Geriatr. Pharmacother., 5, 345351 (2007). - 8. Fialova D, Topinkova E, Gambassi G, et al.: JAMA 293, 1348-1358 (2005). - 9. Megyesi, K., Matuz, M., Benkö, R., et al.: Pharmacoepidemiol Drug Saf. 17(Suppl.1), 147-148 (2008). - 10. Holt, S., Schmiedl, S., Thürmann, P.: Dtsch. Arztebl. Int., 107(31-32), 543-551 (2010). - 11. Beers, MH., Ouslander, J.G., Rollingher, I., et al.: Arch. Intern. Med. 151, 1825-1832 (1991). - 12. Beers, MH., Ouslander, J.G., Rollingher, I., et al.: Ann. Intern. Med. 117, 684-689 (1992). - 13. Donna, M., Fick, R.N., Cooper, J.W., et al.: Arch. Intern. Med. 163, 2716-2724 (2003). 14. The American Geriatrics Society 2012 Beers Criteria Update Expert Panel: American Geriatrics Society Updated Beers Criteria for Potentially Inappropriate Medication Use in Older Adults. J. Am. Geriatr. Soc., 60, 616-631 (2012). 15. McLeod, P.J., Huang, A.R., Tamblyn, R.M., et al.: CMAJ 156, 385-391 (1997). - 16. Hanlon, J.T., Schmader, K.E., Samsa, G.P., et al.: J. Clin. Epidemiol. 45(10), 1045-1051 (1992). - 17. Gallagher P., O'Mahoney D.: Age and Agieing 37, 673-679 (2008). - 18. Laroche, M.L., Charmes, J.P., Merle, L.: Eur J Clin Pharmacol 63, 725-731 (2007). - 19. Mann, E., Böhmdorfer, B., et al.: Wien. Klin. Wochenschr. 124(5-6), 160-169 (2012). - 20. Linstone, H.A., Turoff, M.: The Delphi Method: Techniques and Applications, Reading, Mass. Adison-Wesley 1975, ISBN 978-0-201-04294-8 - 21. Rowe, G., Wright, G.: International Journal of Forecasting, 15, 4 (1999). - 22. O'Mahony, D.: Inappropiate prescribing in older people - lecture. Brit. Geriat. Society Autumn Meeting 2010.

Bor A., Matuz M., Doró P., Soós Gy.: Potentially inappropriate medication among the elderly

Szegedi Tudományegyetem, Gyógyszerésztudományi Kar, Klinikai Gyógyszerészeti Intézet, Szeged, Szikra u. 8. -6700 